\title{
8. SITE 541: TOE OF THE BARBADOS RIDGE COMPLEX ${ }^{1}$
}

\author{
Shipboard Scientific Party ${ }^{2}$
}

Date occupied: 13 February 1981

Date departed: 21 February 1981

Time on hole: 7 days, $16 \mathrm{hr}$.

Position: $15^{\circ} 31.2^{\prime} \mathrm{N}, 58^{\circ} 43.7^{\prime} \mathrm{W}$

Water depth (sea level; corrected m, echo-sounding): 4940

Water depth (rig floor; corrected m, echo-sounding): 4950

Bottom felt (m, drill pipe): 4961

Penetration (m): 459

Number of cores: 50

Total length of core section (m): 459

Total core recovered $(\mathrm{m}): 400.75$

Core recovery $(\%): 87.3$

Oldest sediment cored:

Depth sub-bottom (m): 459

Nature: Radiolarian mudstone

Age: early Miocene

Measured velocity $(\mathrm{km} / \mathrm{s}): 1.70$

Basement: Not reached

Principal results: Drilling at Site 541 penetrated $459 \mathrm{~m}$ of Quaternary to lower Miocene hemipelagic-pelagic sediment. The cored section ranges from marly calcareous ooze to barren mud to radiolarian mud with a concentration of ash beds in the Quaternary and lower Pliocene. Quaternary to Pliocene calcareous muds accumulated at or just below the lysocline, whereas upper, middle, and lower Miocene rocks were deposited principally below the CCD (calcite compensation depth). The absence of terrigenous turbidites suggests deposition of the entire section on a physiographic high.

A reverse fault and associated scaly foliation and stratal disruption occur at $276 \mathrm{~m}$ coincident with stratigraphic inversion of upper Miocene mud over upper Pliocene nannofossil mudstone. Smaller-scale repetitions of a sequence of nannofossil zones and ash beds suggest reverse faults at 75 to 80,172 , and $263 \mathrm{~m}$. In the basal $100 \mathrm{~m}$ of the hole, cores show progressive development of fracturing, intense scaly foliation, and stratal disruption; these cores locally resemble fault gouge. This conspicuous zone of de-

\footnotetext{
${ }^{1}$ Biju-Duval, B., Moore, J. C., et al., Init. Repts DSDP, 78A: Washington (U.S. Govt. Printing Office).

2 Bernard Biju-Duval (Co-Chief Scientist), Institut Français du Pétrole, 92505 Ruei Malmaison, France (present address: Centre National pour l'Exploitation des Océans, $66 \mathrm{Av}$ enue d'Iéna, 75116 Paris, France); J. Casey Moore (Co-Chief Scientist), Earth Sciences and Marine Studies, University of California at Santa Cruz, Santa Cruz, California; James A. Bergen, Department of Geology, Florida State University, Tallahassee, Florida; Grant Blackinton, Hawaii Institute of Geophysics, University of Hawaii at Manoa, Honolulu, Hawaii; George E. Claypool, Branch of Oil and Gas Resources, U.S. Geological Survey, Denver Federal Station, Denver, Colorado; Glenn Foss, Deep Sea Drilling Project, Seripps Institution Oceanography, La Jolla, California: Rodolfo T Guerra, Exploration Services Center, Mobil Exploration and Producing Services, Dallas, Texas; Christoph H. J. Hemleben, Institut und Museum für Geologie und Paläontologie, Universitāt Tubingen, D-7400 Tübingen 10, Federal Republic of Germany; Michael S. Marlow, U.S. Geological Survey, Menlo Park, California James H. Natland, Deep Sea Drilling Project, Scripps Institution of Oceanography, La Jolla California; Carol J. Pudsey, Department of Geology, University of Leicester, Leicester, United Kingdom; G. W. Renz, Deep Sea Drilling Project, Scripps Institution of Oceanography, La Départment de Sciences de la Terre, Université de Savoie, BP 1104, Chambéry, France; Douglas Wilson, Hawaii Institute of Geophysics, University of Hawaii at Manoa, Honolulu, Hawaii (present address: Department of Geophysics, Stanford University, Stanford, California); Audrey Wright, Earth Sciences and Marine Studies, University of California at Santa Cruz, Santa Cruz, California (present address: Deep Sea Drilling Project, Scripps Institution of Oceanography, La Jolla, California).
}

formation may overlie a décollement separating offscraped and underthrust sediment packages.

\section{BACKGROUND AND OBJECTIVES}

The fundamental goal of Site 541, and indeed of Leg $78 \mathrm{~A}$, was complete penetration of the toe of the seismically defined deformation front of the Barbados Ridge (Figs. 1 and 2). Great water depth, thick sediments, and unstable hole conditions had prevented penetration into the seaward margins of Pacific subduction zones. Drilling through an active deformation zone provided an unparalleled opportunity to define stratigraphic, structur$\mathrm{al}$, and diagenetic sequences that can guide interpretations of similar ancient terranes.

The location of Site 541, near the intersection of seismic profiles A1D and A1E on Figure 2, minimized both the total and sub-bottom depths to basement and increased changes of a complete penetration (Fig. 3; Ngokwey et al., this volume). The shallow depth to basement at Site 541 is due to the elevated Tiburon Rise entering the subduction zone just to the east. Specific objectives of Site 541 were:

1) to determine the origin of the discontinuously reflective, possibly allochthonous unit; to establish whether it is scraped off the ocean crust or slumped from some location upslope;

2) to define the structural geology and physical properties of the acoustically chaotic unit and investigate whether folding, faulting, or stratigraphic changes account for its westward thickening;

3) to date and establish the structural nature of the prominent reflector lying below the discontinuously reflective unit;

4) to define the lithology and structural nature of the layered sequence;

5) to date the ocean crust underthrusting the deformation front; and

6) to emplace a downhole seismometer and tiltmeter in the ocean crust.

\section{OPERATIONS}

\section{San Juan to Site 541}

After the vessel was safely clear of San Juan harbor traffic, a 20-min. stop was made to test the ship's thrusters and dynamic positioning system and to "soak" positioning beacons to be used on Leg 78A.

The 500-mi. transit from Puerto Rico to Site 541 was uneventful, except that headwinds of up to 31 knots the first day were followed by swells of up to $9 \mathrm{ft}$., which persisted into the second day of site occupancy. This ad- 


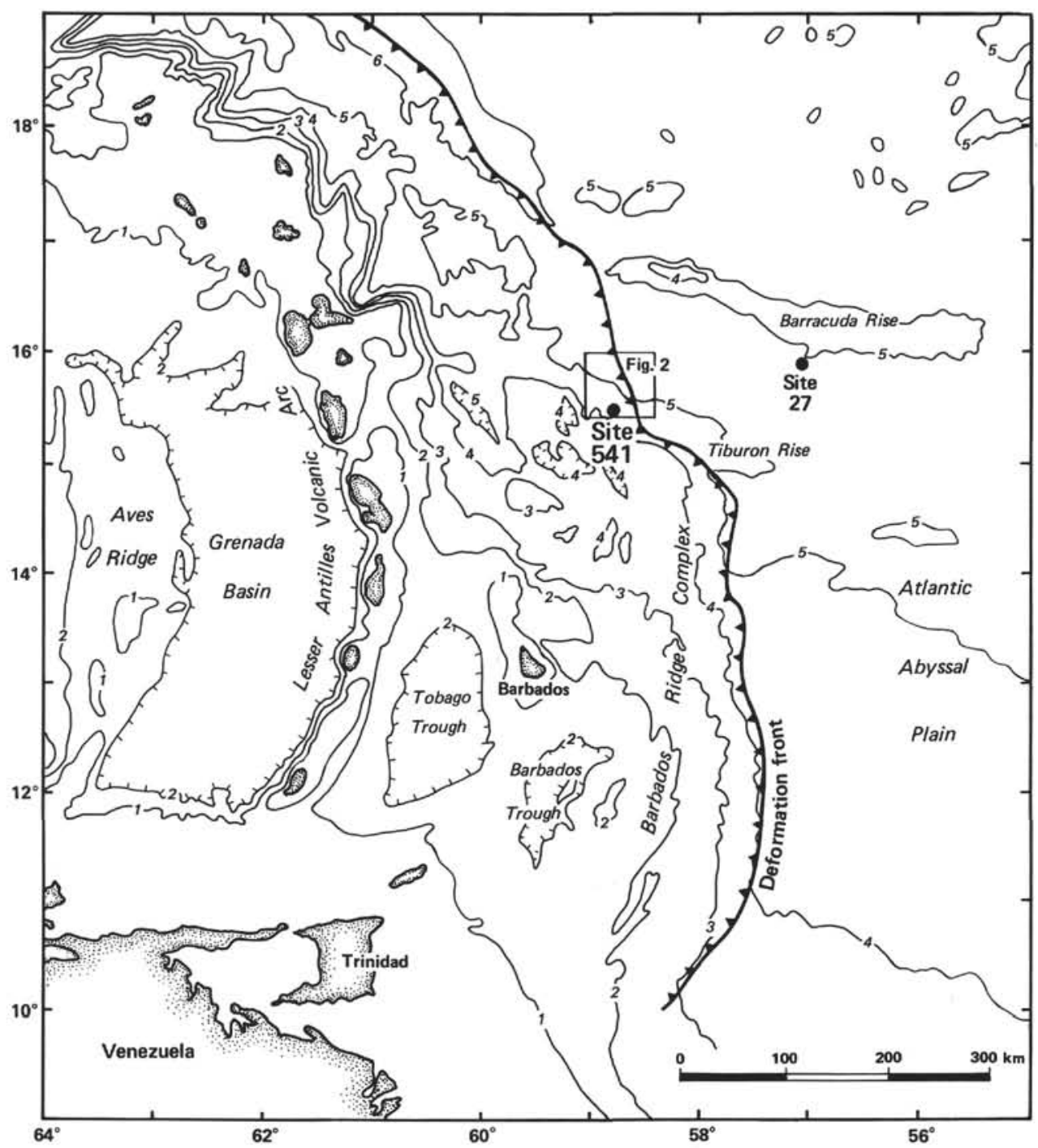

Figure 1. Regional location map. (Note position of deformation front defining eastward boundary of Barbados Ridge and Tiburon Rise underthrusting deformation front near Site 541. Leg 78A drilling area enclosed in box. Contour intervals are in kilometers.)

verse weather combination held the Challenger's average speed to 7.5 knots.

Following a 1.75-hr. presite survey, a positioning beacon was launched at $1404 \mathrm{hr}$. Friday, 13 February, about $135 \mathrm{mi}$. east-northeast of the Island of Martinique.

\section{Site 541-Toe of the Barbados Ridge}

Initial positioning of the vessel was complicated by divergent wind, swell, and current directions and required $2 \mathrm{hr}$. before the pipe trip could begin.

The pipe trip was lengthened by $4.5 \mathrm{hr}$. as 41 suspect joints of drill pipe (identified by the magnetic inspection in San Juan) were laid out. An inner core barrel was pumped down the pipe as the final preparation for spudding. No pressure indication of the barrel landing at the bit was noted after an appropriate interval of pumping. This indicated that the inner barrel had been stopped by a partial obstruction in the pipe or that it had been pumped out through open-ended pipe. An attempt was made to "find" the core barrel with the sand line and overshot, but when the length of the sand line exceeded that of the drill string, we concluded that the hydraulic bit release had operated prematurely during the trip. The sand line was recovered undamaged.

The drill string was then tripped; when the drill collars had been recovered, we discovered that the outer core barrel had come unscrewed from the top sub and had been lost. A new outer core barrel assembly was made up and the drill pipe was again run to the seafloor. Hole 541 was finally spudded at 1525 hr., 15 February. Coring data for the hole are presented in Table 1.

Coring then proceeded smoothly and with excellent core recovery through about $215 \mathrm{~m}$ of nannofossil-rich clay, followed by about $60 \mathrm{~m}$ of clay. At this point a reverse fault was penetrated and the younger nannofossil clay sequence was reentered. No drilling problems were experienced until a second major deformation zone was reached at about $430 \mathrm{~m}$ sub-bottom. Coincident with a very low-recovery core (Core 46 ), high pump pressure and torquing and sticking of the drill string occurred. 


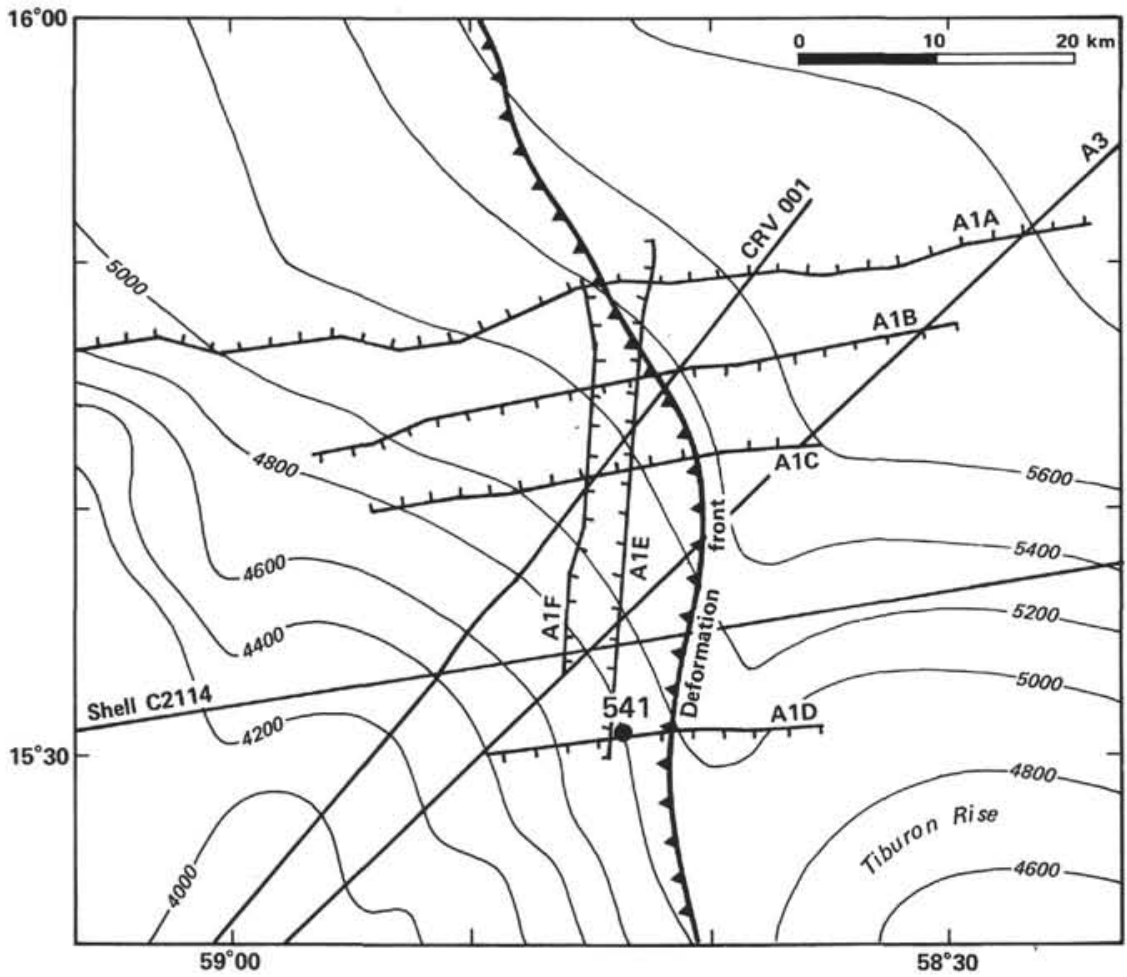

Figure 2. Detailed site location map (box, Fig. 1). (Note position of deformation front and location of seismic reflection lines used for site survey. Bathymetry is in meters. Lines A1A to A1D are from IFP/CNEXO survey [from Ngokwey et al., this volume].)

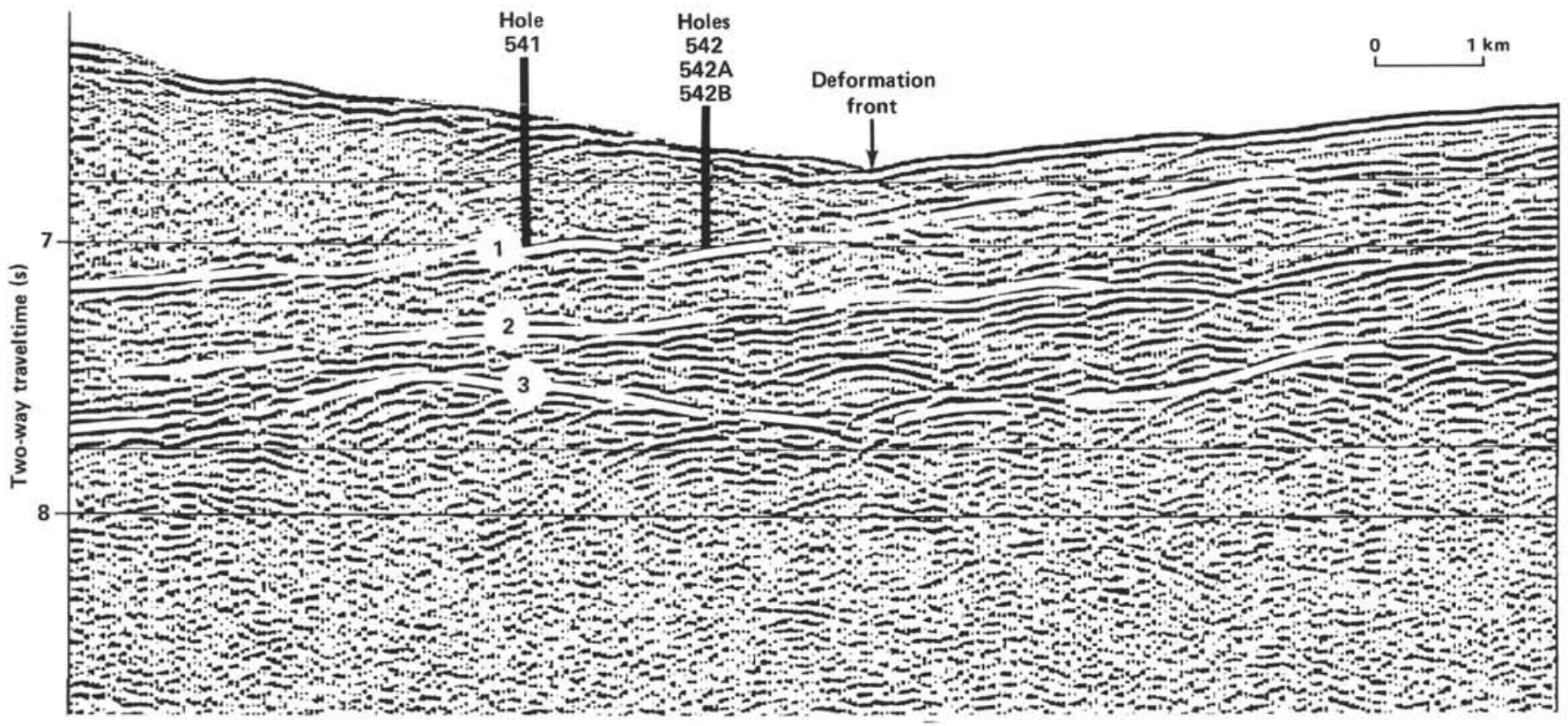

Figure 3. Seismic reflection line A1D (from Ngokwey et al., this volume.) Reflector 1 separates discontinuously reflective and acoustically layered seismic units. Reflector 2 represents a prominent horizon within the acoustically layered unit. Reflector 3 is top of oceanic crust.

The hole was flushed with mud and three additional full cores were taken. Up to $18 \mathrm{~m}$ of fill were encountered following the cores, despite repeated flushes, and sticking tendencies persisted on connections. Rotation could not be regained following the connection for Core 50, and it was necessary to terminate coring operations. A short core was cut by lowering the power sub to the limit of its travel on the guide rails. The core was recovered and a hydraulic bit release go-devil was pumped down to actuate the release mechanism. About $20 \mathrm{~min}$. of manipulating the drill string and pump pressure were required before the bit and associated components were 
Table 1. Coring summary, Site 541.

\begin{tabular}{|c|c|c|c|c|c|c|c|}
\hline $\begin{array}{l}\text { Core } \\
\text { no. }\end{array}$ & $\begin{array}{l}\text { Date } \\
\text { (Feb., } \\
\text { 1981) }\end{array}$ & Time & $\begin{array}{l}\text { Depth from } \\
\text { drill floor } \\
\text { (m) } \\
\text { top bottom }\end{array}$ & $\begin{array}{l}\text { Depth below } \\
\text { seafloor } \\
\text { (m) } \\
\text { top bottom }\end{array}$ & $\begin{array}{l}\text { Length } \\
\text { cored } \\
(\mathrm{m})\end{array}$ & $\begin{array}{l}\text { Length } \\
\text { recovered } \\
\text { (m) }\end{array}$ & $\begin{array}{c}\text { Amount } \\
\text { recovered } \\
(\%)\end{array}$ \\
\hline 1 & 15 & 1635 & $4961-4962$ & $0-1$ & 1 & 0.82 & 80 \\
\hline 2 & 15 & 1810 & $4962-4971.5$ & $1-10.5$ & 9.5 & 8.44 & 88 \\
\hline 3 & 15 & 2005 & $4971.5-4981$ & $10.5-20.0$ & 9.5 & 5.66 & 60 \\
\hline 4 & 15 & 2155 & $4981-4990.5$ & $20-29.5$ & 9.5 & 9.81 & 103 \\
\hline 5 & 15 & 2350 & $4990.5-5000$ & $29.5-39.0$ & 9.5 & 4.04 & 42 \\
\hline 6 & 16 & 0125 & $5000-5009.5$ & $39-48.5$ & 9.5 & 1.12 & 12 \\
\hline 7 & 16 & 0550 & $5009.5-5019.0$ & $48.5-58.0$ & 9.5 & 9.83 & 103 \\
\hline 8 & 16 & 0736 & $5019.0-5028.5$ & $58.0-67.5$ & 9.5 & 9.80 & 103 \\
\hline 9 & 16 & 0912 & $5028.5-5038.0$ & $67.5-77.0$ & 9.5 & 9.82 & 103 \\
\hline 10 & 16 & 1050 & $5038.0-5047.5$ & $77.0-86.5$ & 9.5 & 9.77 & 103 \\
\hline 11 & 16 & 1216 & $5047.5-5057.0$ & $86.5-96.0$ & 9.5 & 6.15 & 65 \\
\hline 12 & 16 & 1540 & $5057.0-5066.5$ & $96.0-105.5$ & 9.5 & 9.92 & 104 \\
\hline 13 & 16 & 1732 & $5066.5-5076.0$ & $105.5-115.0$ & 9.5 & 9.88 & 104 \\
\hline 14 & 16 & 1905 & $5076.0-5085.5$ & $115.0-124.5$ & 9.5 & 9.90 & 104 \\
\hline 15 & 16 & 2040 & $5085.5-5095$ & $124.5-134.0$ & 9.5 & 7.85 & 83 \\
\hline 16 & 16 & 2230 & $5095.0-5104.5$ & $134.0-143.5$ & 9.5 & 8.97 & 94 \\
\hline 17 & 17 & 0243 & $5104.5-5114.0$ & $143.5-153.0$ & 9.5 & 9.4 & 98 \\
\hline 18 & 17 & 0429 & $5114.0-5123.5$ & $153.0-162.5$ & 9.5 & 8.31 & 87 \\
\hline 19 & 17 & 0617 & $5123.5-5133.0$ & $162.5-172.0$ & 9.5 & 9.52 & 100 \\
\hline 20 & 17 & 0756 & $5133.0-5142.5$ & $172.0-181.5$ & 9.5 & 8.53 & 89 \\
\hline 21 & 17 & 0945 & $5142.5-5152.0$ & $181.5-191.0$ & 9.5 & 4.44 & 46 \\
\hline 22 & 17 & 1125 & $5152.0-5161.5$ & $191.0-200.5$ & 9.5 & 9.40 & 98 \\
\hline 23 & 17 & 1302 & $5161.5-5171.0$ & $200.5-210.0$ & 9.5 & 9.40 & 98 \\
\hline 24 & 17 & 1436 & $5171.0-5180.5$ & $210.0-219.5$ & $9.5^{\circ}$ & 8.64 & 90 \\
\hline 25 & 17 & 1619 & $5180.5-5190.0$ & $219.5-229.0$ & 9.5 & 9.84 & 104 \\
\hline 26 & 17 & 1808 & $5190.0-5199.5$ & $229.0-238.5$ & 9.5 & 7.88 & 83 \\
\hline 27 & 17 & 1958 & $5199.5-5209.0$ & $238.5-248.0$ & 9.5 & 9.89 & 104 \\
\hline 28 & 17 & 2150 & $5209.0-5218.5$ & $248.0-257.5$ & 9.5 & 9.92 & 104 \\
\hline 29 & 17 & 2345 & $5218.5-5228.0$ & $257.5-267.0$ & 9.5 & 9.04 & 95 \\
\hline 30 & 18 & 0133 & $5228.0-5237.5$ & $267.0-276.5$ & 9.5 & 9.89 & 104 \\
\hline 31 & 18 & 0312 & $5237.5-5247.0$ & $276.5-286.0$ & 9.5 & 9.94 & 105 \\
\hline 32 & 18 & 0503 & $5247.0-5256.5$ & $286.0-295.5$ & 9.5 & 9.27 & 98 \\
\hline 33 & 18 & 0640 & $5256.5-5266.0$ & $295.5-305.0$ & 9.5 & 10.14 & 106 \\
\hline 34 & 18 & 0830 & $5266.0-5275.5$ & $305.0-314.5$ & 9.5 & 9.10 & 96 \\
\hline 35 & 18 & 1014 & $5257.5-5285.0$ & $314.5-324.0$ & 9.5 & 10.03 & 106 \\
\hline 36 & 18 & 1155 & $5285.0-5294.5$ & $324.0-333.5$ & 9.5 & 2.32 & 24 \\
\hline 37 & 18 & 1418 & $5294.5-5304.0$ & $333.5-343.0$ & 9.5 & 9.80 & 103 \\
\hline 38 & 18 & 1555 & $5304.0-5313.5$ & $343.0-352.5$ & 9.5 & 9.53 & 100 \\
\hline 39 & 18 & 1759 & $5313.5-5323.0$ & $352.5-362.0$ & 9.5 & 4.46 & 47 \\
\hline 40 & 18 & 1943 & $5323.0-5332.5$ & $362.0-371.5$ & 9.5 & 9.83 & 103 \\
\hline 41 & 18 & $213 ?$ & $5332.5-5342.0$ & $371.5-381.0$ & 9.5 & 9.01 & 95 \\
\hline 42 & 18 & 2320 & $5342.0-5351.5$ & $381.0-390.5$ & 9.5 & 9.72 & 102 \\
\hline 43 & 19 & 0115 & $5351.5-5361.0$ & $390.5-400.0$ & 9.5 & 8.98 & 95 \\
\hline 44 & 19 & 0250 & $5361.0-5370.5$ & $400.0-409.5$ & 9.5 & 9.83 & 103 \\
\hline 45 & 19 & 0430 & $5370.5-5380.0$ & $409.5-419.0$ & 9.5 & 9.98 & 104 \\
\hline 46 & 19 & 0740 & $5380.0-5389.5$ & $419.0-428.0$ & 9.5 & 0.69 & 7 \\
\hline 47 & 18 & 1225 & $5389.5-5399.0$ & $428.5-438.0$ & 9.5 & 3.28 & 34 \\
\hline 48 & 19 & 1531 & $5399.0-5408.5$ & $438.0-447.5$ & 9.5 & 7.89 & 83 \\
\hline 49 & 19 & 1818 & $5408.5-5416.0$ & $447.5-455.0$ & 7.5 & 7.28 & 76 \\
\hline 50 & 19 & 2320 & $5416.0-5420.0$ & $455.0-459.0$ & 4.0 & 3.79 & 39 \\
\hline Total & & & & & 459.0 & 400.75 & 87.3 \\
\hline
\end{tabular}

released. The pipe was then pulled until only the BHA (bottom-hole assembly) remained in the hole, and preparations were made for logging.

On the first logging attempt, temperature was being logged downward when the logging sonde was stopped by a soft clay "bridge" only $10 \mathrm{~m}$ beyond the end of the pipe. When attempts to work the tool past the obstruction failed, the tool was recovered and a "short trip" was made. This trip consisted of running the open-ended pipe down to the top of the hole fill at about $415 \mathrm{~m}$ sub-bottom and then pulling back to one stand $(28.5 \mathrm{~m})$ below its earlier position to keep the trouble spot behind pipe. A second logging attempt was aborted due to an electrical problem in the tool that developed about onethird of the way down the pipe. On the third attempt, the sonde logged temperature to about $18 \mathrm{~m}$ beyond the pipe before it again stopped in the soft clay. After numerous attempts to work the tool past the bridge, a static temperature check was made and log function was switched to the density-caliper-gamma ray mode in an attempt to $\log$ the approximately $46 \mathrm{~m}$ of open hole that could be exposed by raising the pipe in the derrick. Un- fortunately, the tool had been damaged by the attempts to penetrate the bridge, and no log could be recorded.

Operations in Hole 541 were terminated at this point and the drill string was recovered, with all pipe on deck at $0600 \mathrm{hr}$., 21 February.

\section{SEDIMENT LITHOLOGY}

\section{Lithostratigraphy}

Site 541 is located in $4950 \mathrm{~m}$ water depth, about $3 \mathrm{~km}$ west of the toe of the accretionary prism. The hole was continuously cored to a sub-bottom depth of $459 \mathrm{~m}$. Recovery of the cored material was excellent $(87.3 \%$, see Table 1) and provides a good record of the lithostratigraphy of the Lesser Antilles forearc accretionary prism (Fig. 4).

Two major tectonic units are present at Site 541, separated by a reverse fault at a sub-bottom depth of 276 $\mathrm{m}$. Tectonic Unit A is $\mathbf{2 7 6} \mathrm{m}$ thick and consists of Recent to upper Miocene sediments. Tectonic Unit B is $184 \mathrm{~m}$ thick and consists of middle Pliocene to lower Miocene sediments. A summary of the seven lithostratigraphic units cored at Site 541 is shown in Table 2. Carbonate percentages measured downhole at Site 541 were determined with the shipboard carbonate bomb (Fig. 4).

The sediments of Tectonic Unit A can be divided into four distinct, conformable lithologic units based on macroscopic core descriptions, smear slide analyses, and carbonate bomb data from the cored interval.

Lithologic Unit 1 is a relatively uniform, 65-m-thick, lower upper Pleistocene to lower Pleistocene nannofossil mud with common ash layers and disseminated ash particles that has been highly deformed by drilling. The upper $40 \mathrm{~m}$ of the unit is olive gray $(5 \mathrm{Y} 5 / 3)$ in color, gradually changing to grayish brown (10YR $5 / 2)$ in the lower $25 \mathrm{~m}$ of the unit. The ash beds are predominantly dark grayish brown (10YR 3/2) to dark gray (10YR 6/1) in color.

Lithologic Unit 2 is a 70-m-thick, lower Pleistocene to upper Pliocene, bioturbated marly nannofossil ooze or marly foraminiferal ooze that has fewer discrete ash layers and a higher calcium carbonate content than is characteristic of Unit 1. It is lighter in color than Unit 1, ranging from light olive gray $(5 \mathrm{Y} 6 / 2)$ to olive gray $(5 \mathrm{Y}$ $5 / 2$ ). There are only two major ash deposits in Unit 2, both closely spaced in Core 12 . Although this unit has

Table 2. Lithologic units, Site 541.

\begin{tabular}{|c|c|c|c|}
\hline Unit & Lithology & $\begin{array}{l}\text { Core range } \\
\text { (core-section, } \\
\mathrm{cm} \text { level) }\end{array}$ & $\begin{array}{c}\text { Depth } \\
\text { below } \\
\text { seafloor } \\
\text { (m) }\end{array}$ \\
\hline 1 & $\begin{array}{l}\text { Nannofossil mud with common } \\
\text { ash layers }\end{array}$ & 1 to 8 & $0-65$ \\
\hline 2 & $\begin{array}{l}\text { Marly nannofossil ooze and } \\
\text { marly foraminifer ooze with } \\
\text { rare ash layers }\end{array}$ & 9 to 15 & $65-135$ \\
\hline 3 & Nannofossil mud with ash layers & 16 to $24-3,50$ & $135-215$ \\
\hline 4 & Mud & $24-3,50$ to $30-6$ & $215-276$ \\
\hline 5 & Nannofossil mud with ash layers & $30-6$ to 37 & $276-340$ \\
\hline 6 & Mudstone & 37 to $47-2,50$ & $340-430$ \\
\hline 7 & Radiolarian mudstone & $47-2,50$ to 50 & $430-459$ \\
\hline
\end{tabular}


been moderately to very deformed by drilling, faint bedding planes indicate that layering is horizontal. Coarsegrained, foraminifer-bearing gravity flow deposits 2 to $4 \mathrm{~cm}$ thick characterize the lower portions of this unit (Cores 13-15).

Lithologic Unit 3 is an 80-m-thick, upper Pliocene to upper Miocene nannofossil mud that contains common ash layers and disseminated ash particles. It has been moderately deformed by drilling. The mud ranges' from gray $(5 Y 6 / 1)$ to olive gray $(5 Y 5 / 2)$ in color and contains faint, dispersed ash mottles in bioturbated intervals. The clay content of the mud increases systematically downsection, as expressed by the generally darker shades of gray characteristic of the lower cores of Unit 3 . The ash layers range from dark olive gray $(5 Y 3 / 2)$ to dark gray (5Y 4/1) to black in color. Bases of these ash beds dip as much as $40^{\circ}$ from horizontal.

Lithologic Unit 4 is $60 \mathrm{~m}$ thick and is differentiated from the overlying sediment by a distinctly lower percentage of calcareous components. It is an upper Miocene, gray $(5 Y 5 / 1)$ to greenish gray $(5 G Y 5 / 1)$ mud with medium light gray burrows and mottles filled with redistributed altered ash. Drilling laminations are found throughout the section. The lower $25 \mathrm{~m}$ of Unit 4 contain several layers of olive gray (5Y 5/2) marly nannofossil ooze, perhaps due to fluctuating levels of the CCD associated with sea-level changes in the late Miocene. The mud is internally deformed and is characterized by variably developed slickensided fracture surfaces throughout the section. This internal deformation is associated with movement along the reverse fault that separates Unit 4 from the underlying Unit 5 of Tectonic Unit B.

The sediments of Tectonic Unit B can be divided into three distinct lithologic units based on macroscopic core descriptions, smear-slide analyses, and carbonate-bomb data from the cored interval. The boundaries between these units are somewhat arbitrarily defined.

Lithologic Unit 5 is a 65 -m-thick, upper Pliocene to upper Miocene, bioturbated nannofossil mud with thin ash layers and dispersed ash particles. A major fault at $276 \mathrm{~m}$ sub-bottom defines the top of this unit. The nannofossil mud ranges from light gray $(5 \mathrm{Y} 6 / 1)$ to gray $(5 \mathrm{Y}$ $5 / 1)$ to olive gray $(5 Y 5 / 2)$ in the top portion of the unit, gradually changing to a darker grayish brown (10YR $5 / 2$ ) downsection. The color change results from an increased clay content toward the base of the unit. The ash layers range from dark gray (5Y 4/1) to black in color. Bedding dips up to $40^{\circ}$ from horizontal. The age and the lithology of Unit 5 is comparable with those of Unit 3 of Tectonic Unit A.

Lithologic Unit 6 is a 90-m-thick, brecciated, intensely fractured, upper Miocene to middle(?) Miocene mudstone with infrequent ash layers and dispersed ash particles. It is differentiated from Unit 5 by a lower percentage of calcareous components. The mudstone ranges from light gray $(2.5 Y 5-6 / 2)$ to olive gray $(5 Y 5 / 2)$ in color and consists of internally fractured drilling "biscuits" (coherent lumps of mudstone) in a matrix of smaller, extensively sheared fragments of similar lithology. These biscuits are commonly bioturbated, with larg- er biscuits having burrows filled with dark gray (5GY $4 / 1$ ) mudstone. The lower $50 \mathrm{~m}$ of this unit contain biscuits of considerable color variation, indicating a mixing of different lithologies. This heterogeneity could be either an artifact of caving between cores or a fault zone fabric. There are several thin layers of nannofossil and foraminifer chalk distributed throughout this unit, suggesting that the level of the CCD fluctuated during its deposition. The age and the lithology of Unit 6 are comparable with those of Unit 4.

Lithologic Unit 7 is a 30 -m-thick, bioturbated, brecciated and highly sheared, light yellowish brown (10YR 6/4), middle Miocene(?) to lower Miocene radiolarian mudstone. The upper part of this unit (Core 47, Section 2 through Core 50, Section 1) also contains lumps and highly sheared zones of light olive brown (2.5Y 5/4) and greenish gray (5Y 5/1) bioturbated mudstones. These color variations indicate that several rock types have been mixed in this section of the hole. This could be the fabric of a fault zone, but hole conditions indicate a lot of caving between cores, so some of the observed mixing and heterogeneity of rock types may be artificial.

The vast majority of the sediments cored at Site 541 show no evidence of having been deposited by current action, but instead seem to have been accumulated by pelagic-hemipelagic settling. The ash beds do not appear to have been redeposited as turbidites, so they probably settled to the seafloor following volcanic eruptions on the Lesser Antilles Island arc. The thin, foraminifer-rich beds at the base of Unit 2 lack distinct grading and lamination, but are probably gravity flow deposits. An alternative explanation is that the level of the CCD fluctuated as oceanographic conditions changed, and deposition of foraminifer-rich beds occurred at times when the local CCD was depressed. This alternative is less likely, however, as such fluctuations are gradual and would not likely produce thin, well-defined foraminiferrich layers.

The environment of deposition of sediments cored at Site 541 was in quiet, deep water adjacent to the Lesser Antilles island arc. Although it is true that terrigenous turbidites were not found in the cored section, this absence may be due to location of the site on a topographic high rather than to great distance from any terrigenous source. Common ash beds and disseminated ash particles in the cores indicate a substantial input of volcanic material from the Lesser Antilles island arc.

Comparison of the ages, thicknesses, and lithologies of Tectonic Units A and B and the distribution of ash layers in Lithologic Units 3 and 5 (see the section on Volcanic Ash, this chapter) suggest that Lithologic Units 3 and 4 above the major fault are lithologically correlative with Lithologic Units 5 and 6 below the fault. In other words, Lithologic Units 5 and 6 represent a repeated section of Lithologic Units 3 and 4. Units 5 and 6 were emplaced beneath Units 3 and 4 by movement along the fault that separates Tectonic Units A and B.

It is uncertain whether Lithologic Unit 7 should be considered a part of Tectonic Unit B or designated as the top of another, deeper Tectonic Unit C, inasmuch as evidence for shear in Unit 7 is abundant and could indi- 


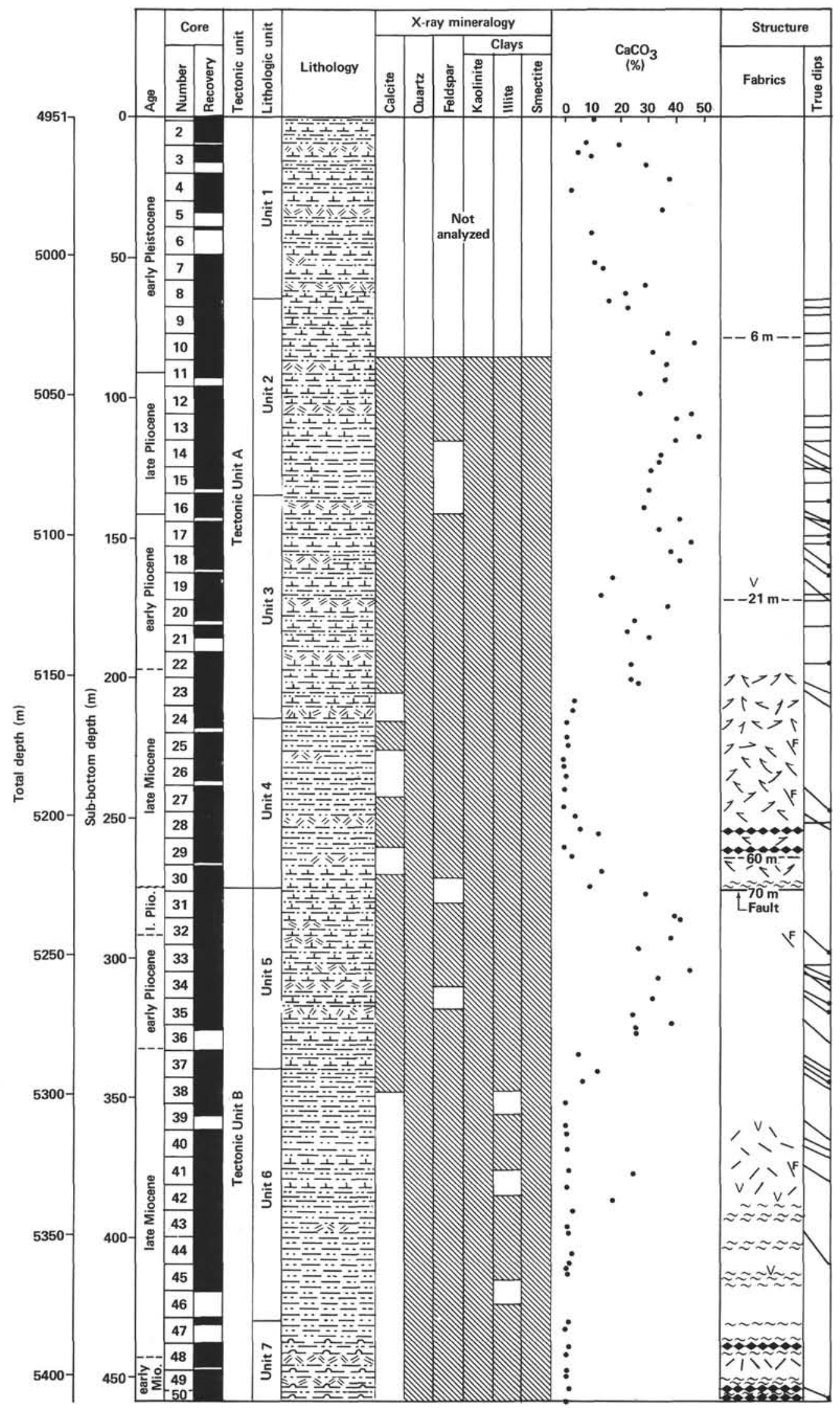

Figure 4. Summary lithology, sediment composition, structure, physical properties, and seismic stratigraphy, Site 541. (In X-Ray Mineralogy columns, blackened areas simply indicate presence. In Structure-Fabrics column, displacements are shown in meters.) 


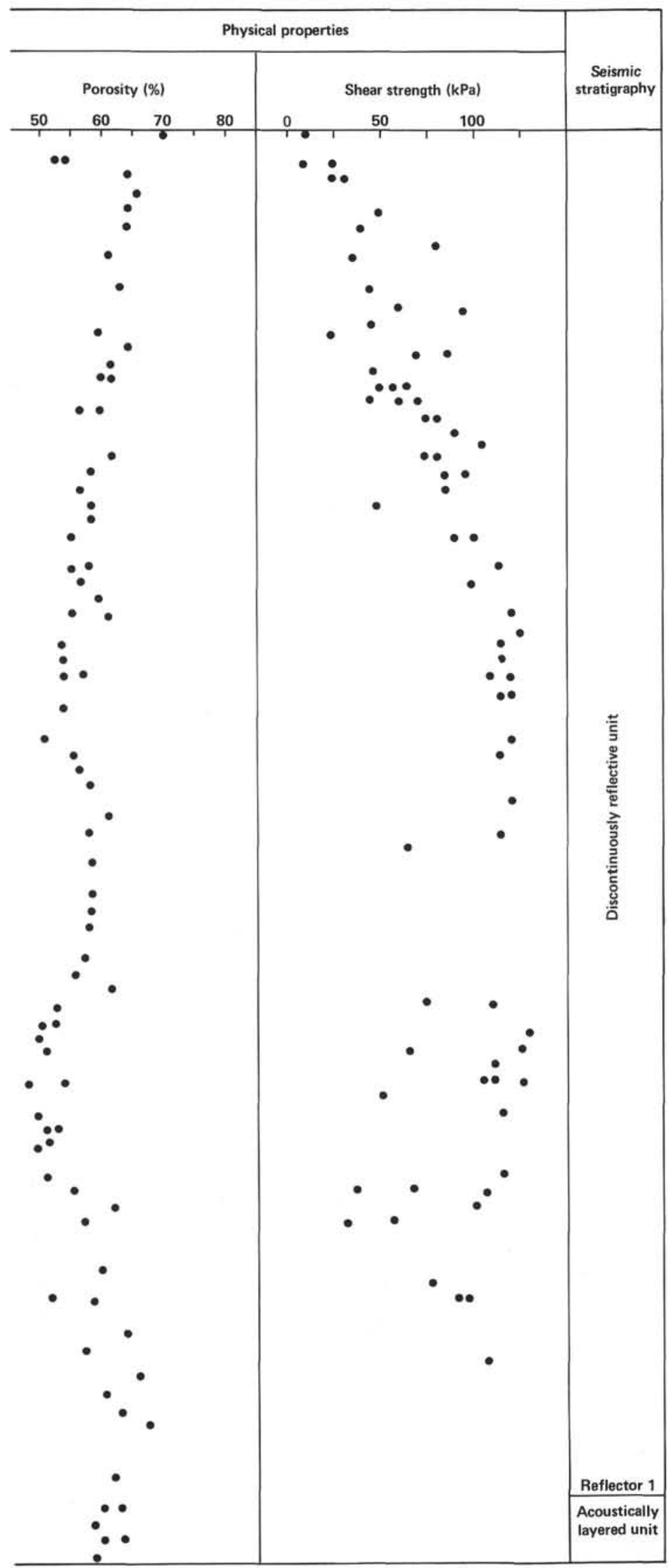

Legend

Lithology

드롤 Marly nannofossil… foraminifer ooze

Nannofossil mud

$\because-7$ Mud-mudstone

Radiolarian mudstone

”N

X-ray mineralogy
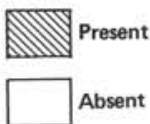

Structure

Fabrics

7 Centimeter-scale slickensides

ح Scaly foliation

II Fractures

V Vein

structure

$\ldots$ Stratal

disruption

F Small faults

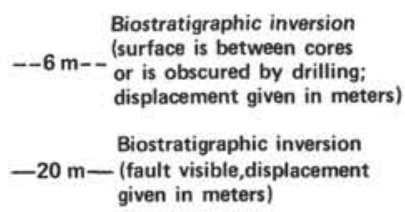

True dips

$\checkmark$ Right-way up

Tops unknown

Figure 4. (Continued). 
cate another fault. Geophysical profiles indicate that drilling at Site 541 may have just penetrated Reflector 1, in which case Unit 7 may represent the topmost lithology of the sedimentary section below that reflector.

\section{Bioturbation}

Probably the entire section is bioturbated, but burrowing is much more pronounced in the lithified muds of the lower tectonic unit. Bioturbation was first noted in Core 8, but no burrows could be identified due to intense drilling disturbance. The first burrowed ash bed occurs in Core 10, Section 3. Gray ash beds generally have bioturbated contacts, with gray ash carried down into olive gray mud below, and olive gray mud from above carried down into the ash bed. These occurrences provide way-up evidence. Burrow mottling occurs from Cores 10 to 18 .

The first recognizable Chondrites appears in Core 19 and is accompanied by larger (up to 5-mm diameter) cylindrical burrows mostly oblique to bedding. Throughout the section, Chondrites burrows are 1 to $2 \mathrm{~mm}$ in diameter. Core 21 contains Chondrites, Planolites, rarer Cylindrichnus, and a possible Zoophycus. Burrow mottling was noted in Cores 22 to 35 , but few ichnogenera were identified.

Core 36 was the first to be sawed in half rather than cut, and the sawed surfaces expose burrows extremely well. Planolites is abundant, and Cylindrichnus, Chondrites, and composite burrows also occur. A few vertical burrows resemble Teichichnus in shape and size but lack a meniscus fill. Cores 37 and 38 are mottled; 39 is too soupy to see burrows. Cores 40 to 45 have a well-preserved burrow assemblage as follows:

$$
\begin{array}{ll}
\text { Planolites } & \text { - abundant } \\
\text { Chondrites } & \text { - abundant } \\
\text { Zoophycus } & \text { - common } \\
\text { Planolites/Chondrites } & \text { - fairly common } \\
\text { (composite large) } & \\
\text { Cylindrichnus } & \text { - rare }
\end{array}
$$

in addition to abundant nondescript near-cylindrical burrows.

The yellow brown mudstone in Core 47 contains only a few indistinct Chondrites burrows.

All these burrows have been previously described from many DSDP cores. They are made by deposit feeders that thoroughly rework the sediment and destroy original bedding. However, where traces of bedding remain in cores (e.g., ash beds) and also in outcrops, many burrows tend to be either flattened parallel to bedding (e.g., Planolites) or to occur in bedding-parallel rows (Chondrites and Planolites). This fact is important for structural measurements.

Zoophycus burrows extend across cores at a low angle to bedding (see Ekdale, 1974). It was noted at this site that the meniscus fill of Zoophycus is not always symmetrical about the center but tends to be offset with a long limb and a short limb (Fig. 5). The long limb is downsection. In heavily burrowed, tectonically disturbed sequences this could be the only method to detect the way up of the strata.

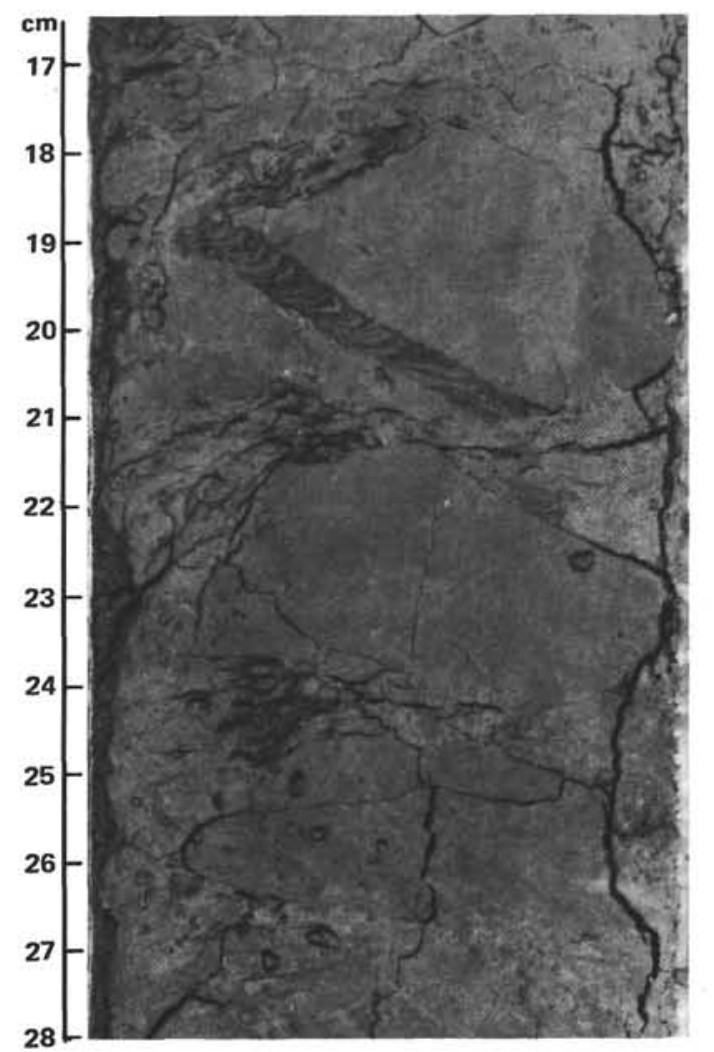

Figure 5. Zoophycus burrow with asymmetric meniscus fill (Sample $541-40-5,17-28 \mathrm{~cm}$ ). (The larger limb of the asymmetric fill is downsection.)

The intense bioturbation at this site, particularly in Cores 40 to 45 , indicates a slow sedimentation rate allowing time for complete reworking. All the ichnogenera occur in a wide depth range, so the assemblage gives no definite indication of water depth.

\section{X-Ray Mineralogy}

Sixty-five samples from Cores 11 to 50 were analyzed using the shipboard X-ray diffractometer. Samples were prepared on glass slides in the same way as smear slides, then dried on a desiccating oven for at least one half hour. Each sample (one per core, plus some distinctive layers such as ashes) was X-rayed twice (oriented dry sample from $2 \theta=3^{\circ}$ to $35^{\circ}$, and glycolated, from $2 \theta=$ $3^{\circ}$ to $15^{\circ}$ ). Minerals were identified by their characteristic peaks on the diffractogram (Carroll, 1970, table 12).

Minerals identified include quartz, alkali feldspar and plagioclase, calcite, and the clay minerals kaolinite, illite, and smectite. The shipboard diffractometer gives a pseudo-peak at $2 \theta=71 / 2^{\circ}$, with a blank glass slide as the sample. Results are summarized in Figure 4.

Quartz is present in all samples and shows no systematic increase or decrease down the hole. One or both feldspars are present, in most samples: their proportions appear to vary widely and unsystematically. There is very little feldspar from 115 to 200 and 270 to $320 \mathrm{~m}$ sub-bottom (except for an ash layer at $180 \mathrm{~m}$ ). Calcite, more accurately analyzed by the carbonate bomb meth- 
od, is present from 0 to 205 and 270 to $345 \mathrm{~m}$ sub-bottom. Of the clays, kaolinite is present in all samples. Illite is present down to $340 \mathrm{~m}$, where it decreases rather sharply (much lower peak height): this decrease corresponds to a downward increase in smectite peak height and sharpness. Of the distinctive lithologies, all the gray and black ashes have a high feldspar content and the feldspar peaks are very sharp. The bluish and greenish muds associated with the ashes are rather variable, some being feldspar-rich and others calcareous. There is little difference between gray brown and olive gray muds except that the latter may contain slightly less kaolinite: colors may result from chemical rather than mineralogical composition.

The smectite-rich interval below $380 \mathrm{~m}$ corresponds to the zone of pervasively sheared, scaly clays.

\section{Volcanic Ash}

The eastern slope of the Barbados Ridge is in an unusually favorable position for the preservation of ash beds derived by explosive volcanism from the Lesser Antilles arc. The sediments are almost entirely hemipelagic and lack obvious turbidites (although some redeposition of foraminifers has occurred-see the section on Paleoenvironment, this chapter); hence redeposition of ash has not occurred. Therefore, ash from individual eruptions, particularly the major eruptions, is well preserved, with bioturbation being the only disturbing sedimentological factor.

In Hole 541, recognition of volcanic ash in the upper few cores was complicated by intense core deformation during drilling. Not even the distinctive Roseau ash (e.g., Sparks et al., 1980) is recognizable in the the upper few meters of Core 2, where it should occur. Throughout most of the cores below the intensely disturbed upper few meters, major ash falls are readily apparent, although minor fine ash falls have been largely redistributed by burrowing organisms. In or near tectonic shear zones (Cores 25-30 and 40-50), additional disturbance of ash beds has undoubtedly resulted from faulting. All of these factors complicate interpretation of rates, frequency, and volume of explosive Lesser Antilles volcanism in the affected intervals. The least disturbed portions of the cores are from about 60 to $200 \mathrm{~m}$ below the seafloor (Cores 8-23) and 290 to $330 \mathrm{~m}$ below the seafloor (Cores $32-36$ ). Cores 8-23 represent a nearly stratigraphically uninterrupted sequence of marly calcareous oozes and clays ranging in age from Miocene to late Pliocene.

Ash beds in cores from Hole 541 are as much as $7 \mathrm{~cm}$ thick, but are clearly recognizable as ash beds even when only 1 to $2 \mathrm{~cm}$ thick. The thicker beds typically have sharp lower contacts and bioturbated upper contacts. All of these have a uniform grain-size distribution and no scour or internal bedding, hence are not turbidites. They are generally very dark gray, nearly black, in color, and some are rich in crystals (plagioclase, quartz, clinopyroxene, orthopyroxene, amphibole, and biotite, in order of decreasing abundance). This reflects the marked density sorting between crystals and glass that occurs in the atmosphere before the materials are deposited, with crystals settling faster than glass (Carey and Sigurdsson, 1980). Thinner beds can be either black or gray in color, with gray colors possibly resulting from a high concentration of leucocratic minerals in the ash, high $\mathrm{SiO}_{2}$ content of glass, or mixing with adjacent hemipelagic sediments. Very thin beds tend to have been dispersed up and down the cores for tens of centimeters by burrowing organisms. Many of these can still be recognized by the specks of almost pure ash in the burrow traces. Much of the glass in the ashes of all the cores has been extensively altered to clay minerals (illite and smectite, as revealed by X-ray diffractograms). In smear slides, the glass appears charged with moderately birefringent clays and iron hydroxides.

In all, there are 119 ash beds in the Hole 541 cores, of which 29 are major ash falls more than $2 \mathrm{~cm}$ thick. The upper 18 of these major ash beds range in age from late Miocene to Quaternary. The remainder occur below the distinct reverse fault in Core 30, and of these, 10 repeat major ash beds in the upper 18. In all then, 19 intact major ash falls appear to have been sampled. There are two dominant intervals of major ash-producing eruptions, one in the early Pliocene, and one in the late Pleistocene. Miocene and late Pliocene activity was more subdued.

The unusually high recovery throughout most of Hole 541 allows an interesting comparison to be made of the ash stratigraphy in age-equivalent strata above and below the fault in Core 30. Shear deformation appears to be minimal in the carbonate-rich segments of the hole, whereas it is extensive in clays and mudstones. In Cores 18 and 33 there occur two closely spaced ash falls, separated by fewer than $10 \mathrm{~cm}$ of hemipelagic carbonate ooze. Assuming that these are identical ash beds, comparison of core photos shows that near the pair, there are no fewer than 7 other major ash beds that occur at precisely the same depths in both groups of cores (see Natland, this volume). Cores 19 and 36 are markedly more enriched in clays than higher cores, but occur at almost exactly the same depth below the ash-bed pair both above and below the fault. For about $30 \mathrm{~m}$ or so, evidently, precisely correlative sequences from above and below the fault can be matched. Below this, however, in the clay-rich materials, faulting and shear deformation occur in both sequences, making it impossible to correlate ash beds. The differences in stratigraphy of these two clay-rich intervals occur because one or both of them contain faults.

\section{STRUCTURAL GEOLOGY}

The most conspicuous structure documented at Site 541 is a reverse fault at $276 \mathrm{~m}$ (Core 30) along which Miocene mud has been emplaced structurally above Pliocene nannofossiliferous mud. More pervasive, smallerscale deformational features are progressively developed in the $75 \mathrm{~m}$ of section immediately above this fault. Three stratigraphic inversions also occur above the fault. The Pliocene section immediately below this fault is gently dipping but otherwise undeformed. Approximately $100 \mathrm{~m}$ above the base of the hole, fracturing and penetrative shearing are again important and probably formed 
in or adjacent to another major fault zone. In this section of the Site 541 report, structural features are described in detail, proceeding from the top to the bottom of the hole. Observations are depicted graphically in Figure 4.

Horizontal layers that had not been reoriented by drilling were first noted in Core 8, below $59 \mathrm{~m}$ (sub-bottom depth). The first dipping layers were measured in Core 14; they have true dips of about $20^{\circ}$. From this point until the onset of internal fracture and flow in Core 23, alternating sections of mud and ooze 5 to $15 \mathrm{~m}$ thick are characterized by either horizontal attitudes or layers dipping on average $20^{\circ}$, but as much as $40^{\circ}$. In several cases, attitudes were obtained on right-way-up ash layers with sharp bottoms and bioturbated tops. Note that dips do not increase progressively downhole as would be the case if tilting had occurred during deposition. The alternation of horizontal and dipping layers indicate instead that some restricted stratigraphic intervals are either tilted or gently folded, perhaps due to gravity-driven slumping or small displacements along décollements.

The first hint of more pervasive deformation occurs in a few $10-\mathrm{cm}$ intervals in Cores 23 and 24, but most of Cores 25 to 29 and the upper $130 \mathrm{~cm}$ of Core 30 are characterized by incipient to thorough internal disruption. Bioturbation structures (burrowing, mottling) are undistorted locally, but generally they have been obliterated. Cores are pervaded by slickensided, polished surfaces that can be broken out of drilling biscuits on a scale of $1 \mathrm{~cm}$ or so. These are interpreted as slip surfaces, accommodating and distributing small $(<<1 \mathrm{~mm})$ displacements throughout the section, but the surfaces appear not to have any preferred orientation. They are definitely less penetrative and oriented than "scaly" foliation, which is developed for about $20 \mathrm{~cm}$ above the fault in Section 6 of Core 30. Scaly mudstone is common in Cores 42 to 50 and is more fully described later. A 7-cm-long sharp fault, dipping $60^{\circ}$, with striations pitching $80^{\circ}$ on its polished surface, occurs in Core 25 , Section 5. The deformation and distortion in Cores 25 to 30 is described best as mesoscopic plastic flow accommodated in part along mesoscopically visible discontinuities ( $=$ polished surfaces). This flow has also resulted in stratal disruption, because some layers of distinctly colored mud were broken up, or disharmonically folded and swirled, sometime prior to the development of drilling laminations. Other layers, such as in Core 30, Section 6, apparently were juxtaposed along steeply dipping faults. The stratal disruption was obviously complex, but its nature is obscure because disrupted layers have been subsequently rotated along horizontal drilling fractures. We believe all of this internal deformation is related to the major fault discussed next.

This fault, emplacing Miocene structurally above Pliocene, is visible in Core 30, Section 6, from 122 to 143 $\mathrm{cm}$. Pervasively sheared, scaly, dark olive gray Miocene mud is separated from lighter gray Pliocene nannofossil-rich mud by a black-stained zone up to $5 \mathrm{~mm}$ thick that represents the actual fault surface. Offset nannofossil zones suggest $70 \mathrm{~m}$ of throw across the fault. The in situ orientation of the fault is difficult to determine because it has been reoriented drastically by rotations along drilling laminations, but its appearance in several biscuits over the interval mentioned suggests that it is either moderately to steeply dipping or perhaps folded or imbricated in situ. In any case, we sampled only a miniscule part of the fault and can only guess its actual orientation. It is important to note, however, that whatever its attitude, reverse dip slip must have occurred along it to emplace gently dipping older strata over younger.

In addition to the major fault at $276 \mathrm{~m}$, nannoplankton biostratigraphy indicates repeated sections near the base of Core 9, at the base of Core 19, and possibly within Core 29 , although the actual physical features responsible for these inversions (reverse faults, small slumps) were not observed in the cores. Two ash beds in Core 18 may be equivalent to ash beds in Core 20 , and a paleomagnetic reversal event is repeated in Cores 18 and 20 (see the section on Paleomagnetics, this chapter). There is also a change in dip, corresponding with this stratigraphic inversion, from about $40^{\circ}$ in Cores 18 and 19 to horizontal in Cores 20 to 22. Although the vertical offset across the fault at $276 \mathrm{~m}$ is only $70 \mathrm{~m}$, similar nannofossil assemblages occur in Cores 23 and 38 (205 and $345 \mathrm{~m}$ ), suggesting a total of about $130 \mathrm{~m}$ of throw. Thus the fault at $263 \mathrm{~m}$ apparently accommodates about $60 \mathrm{~m}$ of throw.

Aside from a few centimeter-scale, randomly oriented polished surfaces and a sharp steeply dipping fault in the first section of Pliocene mud below the fault at $276 \mathrm{~m}$, the sediments appear to be internally undeformed in contrast to sediments above the fault. However, the section from Cores 31 to 41 is all gently to moderately dipping; 16 attitudes ( 5 definitely right-wayup) average $25^{\circ}$ but range as high as $45^{\circ}$. A sharp, $50^{\circ}$ fault with striations pitching 65 to $75^{\circ}$ cuts across Core 32 , Section 6. Beginning in Core 40 , interval deformation is again evident and is expressed as fracturing in biscuits of coherent mudstone. Breccia is locally developed between some biscuits, probably having formed from drilling-induced disruption of fractured mudstone. The intensity of fracturing is variable in Cores 40,41 , and 42 . Judging from the fine preservation of burrows, displacements along the fractures were negligible.

Core 42, Section 5 marks the first appearance of penetratively deformed, foliated, scaly mudstone. This scaliness is the mesoscopic expression of slip along innumerable closely spaced subparallel surfaces. Typical samples of affected mudstone can be disaggregated into small polished chips. The fabric of scaly mudstone in these cores strongly resembles deformed, or "sheared," mudstones and serpentinites in on-land fault zones, and there was general agreement on board that the prevalence of this feature from Cores 42 to 50 indicates that we had penetrated another major fault zone. The polished surfaces are strongly oriented and impart a definite foliation to mudstone within drilling biscuits, but the orientation of the foliation generally varies from biscuit to biscuit, possibly due to rotation during drilling. We estimate that horizontal attitudes are most abundant, especially in Cores 48 to 50 . Typically, scaly mud- 
stone occurs in 10- to 20 -cm-thick zones separating intervals comprising biscuits of coherent or fractured burrowed mudstone, but some scaly zones are as much as $1 \mathrm{~m}$ thick. Some zones include lens-shaped inclusions, augen, or wispy streaks of mudstone or ash that are colored differently from the scaly matrix and thus are presumably tectonic inclusions recording modest stratal disruption and mixing in shear zones.

Some sections of Cores 49 to 50 also contain intervals comprising angular fragments of different lithologies surrounded by soupy drilling mud and breccia. Their fabric is so different from the foliated intervals that we interpret them as cavings that collected in the hole as the drill string was run up and down to prevent sticking. Some of the foliated and fractured zones undoubtedly were further disturbed by drilling, as suggested by swirling patterns in Cores 49 and 50 .

One other small-scale structure was documented at Site 541. "Vein structure," or "veins," as defined on Leg 67 , refers to dark 1-mm-thick planar or curviplanar discontinuities generally spaced about 1 to $5 \mathrm{~mm}$ apart on cut surfaces of cores. We noted very rare veins in biscuits in Cores 19, 40, 41 and 45. They appear to be oriented either vertically or horizontally. They differ from veins described on Leg 67 (Cowan, 1982), and "spaced cleavage" described on Leg 66 (Lundberg and Moore, 1982), in that individual components of sets are not subparallel but rather anastomose around a common "zone axis." The net effect is that the mud is segmented into roughly cylindrical, irregular rods, 1 to $3 \mathrm{~mm}$ in diameter, parallel to the zone axis, rather than thin planar or curviplanar panels. The significance of these structures is unknown, pending further investigation.

In summary, we feel that we penetrated two major zones of deformation at Site 541. One of them formed above a major fault zone that repeats the stratigraphic section. We did not detect any stratigraphic inversion or repetition in the lower deformed zone, but much of the mudstone is barren of fossils. Smectite is decidedly more abundant in the internally deformed sediments in Cores 25 to 30 and 42 to 50 (see the Lithology section, this chapter), which possibly causes the localization of deformation.

\section{BIOSTRATIGRAPHY}

The biostratigraphy described herein is based on shipboard investigations. For more complete summaries, see Bergen (nannofossils-this volume) and Renz (radiolarians-this volume).

\section{Nannofossils}

A biostratigraphic summary of Site 541 nannofossils, radiolarians, and foraminifers is plotted with depth, age, and paleomagnetics in Figure 6 .

Nannofossil-bearing sediments at Site 541 range in age from late Miocene (CN9a) to early late Pleistocene. Pliocene sediments generally contain common and moderately preserved calcareous nannofossils. Miocene sediments are either barren or contain relatively few and often poorly preserved floras.
Four stratigraphic repetitions of section are recognized at Site 541. The largest of these is in Core 30, Section 6, where an upper Miocene mud (CN9a) overlies an upper Pliocene nannofossil mud (CN12a). Two smaller repetitions of section occur within the larger repeated unit. The first of these is in upper Miocene muds above Sample 541-29-4, 75-76 cm, where Amaurolithus primus, $A$. delicatus, Discoaster surculus, and $D$. quinqueramus disappear. $D$. berggrenii then enters in Sample $541-28, C C$, followed by $D$. surculus and $D$. quinqueramus in the top half of Core 28. The amauroliths are not found again until the base of Core 24 . The second, small repetition occurs between Sample 541-20-1, 45-46 $\mathrm{cm}$ and Section 541-19,CC. At this break, sediments from the Sphenolithus neoabies Subzone (CN11a) are found below those of Ceratolithus acutus Subzone (CN10b).

A final repetition occurs in lower Pleistocene sediments from Core 9. Cyclococcolithina macintyrei, which is last seen in Sample 541-10-3, 75-76 cm, is found again in Core 9, Sections 5 through 2. In addition, a succession of Gephyrocapsa species seen in Core 10 is repeated in the top five sections of Core 9 and the bottom of Core 8 . This repetition involves approximately $6 \mathrm{~m}$ of section.

There are two places in Hole 541 where section is missing. The first is between Samples 541-37-1, 35-36 $\mathrm{cm}(\mathrm{CN} 10 \mathrm{~b})$ and $541-36, \mathrm{CC}(\mathrm{CN} 9 \mathrm{~b})$, where the Triquetrorhabdulus rugosus Subzone (CN10a) is missing. This hiatus is not seen uphole. A second hiatus is located in the upper part of Core 13. Here, only Sample 541-13-1, $75-76 \mathrm{~cm}$ is from the D. pentaradiatus Subzone (CN12c).

Core 1 contains the only upper Pleistocene, nannofossil-bearing sediments in the Leg 78A sites. Gephyrocapsa oceanica and Ceratolithus cristatus occur in this core, but not Pseudoemiliania lacunosa or Emiliania huxleyi. It is possible that the absence of $E$. huxleyi is due to deposition below the compensation depth of that species.

Samples 541-2-1, 70-72 cm through 541-11-3, 131$132 \mathrm{~cm}$ contain $P$. lacunosa but have no discoasters. This whole interval is placed in the lower Pleistocene. The Pliocene/Pleistocene boundary is placed at the last common occurrence of $D$. brouweri and agrees with the foraminifers. The occurrence of Cyclococcolithina macintyrei (up to Sample 541-10-3, 75-76 cm and in Core 9, Sections 2 to 5) places these samples in the Cyclococcolithina macintyrei Zone of Gartner (1977).

Samples 541-11-4, 8-9 cm through 541-16-4, 13-14 cm are assigned to the upper Pliocene, on the basis of the last occurrences of $D$. brouweri and Reticulofenestra pseudoumbilica. Sphenolithus neoabies, whose last occurrence is used in conjunction with that of $R$. pseudoumbilica, disappears after Sample 541-16-3, 13-14 cm. The upper Pliocene is divided up as follows:

1) Sample $541-11-4,8-9 \mathrm{~cm}$ to Section $541-12, \mathrm{CC}-$ Calcidiscus macintyrei Subzone (CN12d);

2) Sample 541-13-1, 30-31 cm-Discoaster pentaradiatus Subzone (CN12c);

3) Samples $541-13-2,30-31 \mathrm{~cm}$ to $541-13-5,30-31$ $\mathrm{cm}-$ Discoaster surculus Subzone (CN12b); and 


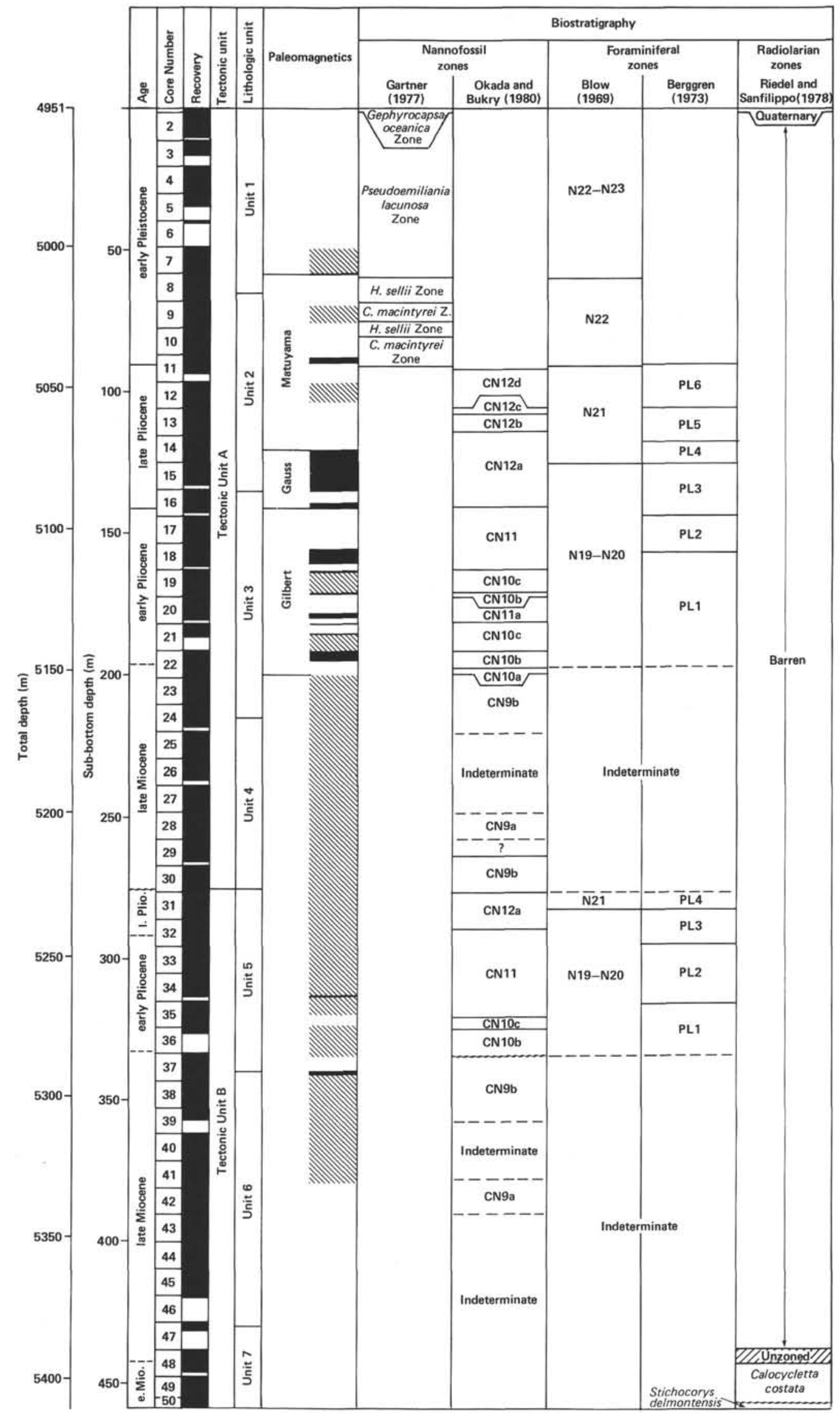

Figure 6. Summary biostratigraphy and magnetostratigraphy, Site 541. (Polarity normal intervals are black, polarity reversed intervals are white, and polarity uncertain intervals [or intervals with no data] are diagonally striped.) 
4) Samples $541-13-6,30-31 \mathrm{~cm}$ to $541-16-4,13-14$ $\mathrm{cm}-$ Discoaster tamalis Subzone (CN12a).

Sample 541-16-5, 13-14 cm through Sample 541-18$6,43-44 \mathrm{~cm}$ are assigned to the Reticulofenestra pseudoumbilica Zone (CN11). $R$. pseudoumbilica, Sphenolithus abies, and $S$. neoabies are found throughout this interval. Discoaster asymmetricus becomes common by Sample 541-17-2, 40-41 cm, and this marks the beginning of its acme.

Samples 541-18,CC through 541-19-5, 60-61 cm are placed in the Ceratolithus rugosus Subzone $(\mathrm{CN} 10 \mathrm{c})$, based on the presence of Amaurolithus tricorniculatus and absence of C. acutus. C. acutus is present in Sample $541-19-6,79-80 \mathrm{~cm}$ through Section 541-19,CC. This interval is placed in the Ceratolithus acutus Subzone (CN10b).

Core 20, Section 1 through Core 22, Section 2 contain approximately $21 \mathrm{~m}$ of section seen above Section $541-19$,CC. Samples 541-20-1, 45-46 cm through 54120-7, 4-5 cm contain $R$. pseudoumbilica and $S$. neoabies but not $A$. tricorniculatus and $D$. asymmetricus. This interval is assigned to the Sphenolithus neoabies Subzone (CN11a). Sections 541-20,CC to 541-21,CC contain A. tricorniculatus and are in the Ceratolithus rugosus Subzone (CN10c). The occurrence of C. acutus from Samples 541-22-1, 22-23 cm to 541-22-4, 22-23 $\mathrm{cm}$ indicates that this section is from the Ceratolithus acutus Subzone (CN10b). Samples 541-22-5, 22-23 cm and 541-22-6, 22-23 cm do not have $C$. acutus and $D$. quinqueramus and are placed in the Triquetrorhabdulus rugosus Subzone (CN10a). Sections 541-22, CC to 541$24, \mathrm{CC}$ all contain $D$. quinqueramus. $A$. primus and $A$. delicatus are in only some of these samples because of poor preservation. This interval is assigned to the Amaurolithus primus Subzone (CN9b) of the late Miocene.

Cores 25 through 27 are barren except for sparse assemblages in Section 541-27,CC. Core 28 contains $D$. berggrenii throughout, and no amauroliths. It is assigned to the Discoaster berggrenii Subzone (CN9a). The top three sections of Core 29 are barren except for the occurrence of numerous discoasters in Sample 541$29-2,75-76 \mathrm{~cm}$. This sample is probably older than the Discoaster berggrenii Subzone (CN9a), but lacks any marker species. Samples 541-29-4, 75-76 cm to 541-30$6,130-131 \mathrm{~cm}$ contain $D$. surculus, $D$. quinqueramus, $A$. primus, $A$. delicatus, but not $D$. berggrenii. This section is from the Amaurolithus primus Subzone (CN9b) and is younger than Core 28 .

A major stratigraphic inversion occurs between Samples $541-30-6,130-131 \mathrm{~cm}$, and $541-30-6,135-136 \mathrm{~cm}$. Samples $541-30-6,135-136 \mathrm{~cm}$ to $541-33-2,58-59 \mathrm{~cm}$ are assigned to the late Pliocene Discoaster tamalis Subzone $(\mathrm{CN} 12 \mathrm{a})$ on the basis of occurrence of $D$. tamalis and absence of $R$. pseudoumbilica. S. abies and $S$. neoabies have their last occurrences in Sample 541-32-2, 69-70 cm and Sample 541-32-1, 45-46 cm, respectively.

Samples $541-33-3,58-59 \mathrm{~cm}$ to $541-35-3,69-70 \mathrm{~cm}$ contain $R$. pseudoumbilica and no $A$. tricorniculatus. This indicates that this section is in the $R$. pseudoumbilica Subzone (CN11). The beginning of the acme of $D$. asymmetricus can be placed in Core 33, Section 6. Sample 541-35-4, 64-65 cm to Section 541-35, CC are placed in the Ceratolithus rugosus Subzone (CN10c), based on the presence of $A$. tricorniculatus and the absence of $C$. acutus. All samples from Core 36 are assigned to the Ceratolithus acutus Subzone (CN10b), based on the occurrence of that species alone. A hiatus is present below this as $D$. quinqueramus, $D$. surculus, and $A$. primus are found from Samples 541-37-1, 35-36 cm to 541-39$3,21-22 \mathrm{~cm}$. This interval is placed in the Amaurolithus primus Subzone (CN9b). Barren intervals are common in Cores 38 and 39. Cores 40 to 41 , Section 2 are totally barren.

Samples $541-41-4,34-35 \mathrm{~cm}$ to $541-42-5,69-70 \mathrm{~cm}$ usually contain $D$. berggrenii or $D$. surculus. No amauroliths are found in this section, so it is placed in the Discoaster berggrenii Subzone (CN9a). The occurrence of nannofossils in this interval may suggest a small repetition of section above Sample 541-42-4, $85-86 \mathrm{~cm}$, but this repetition is hard to be sure of because of poor assemblages. Section 541-42,CC contains the last nannofossils of any kind. Cores 43 to 50 are barren.

\section{Radiolarians}

Siliceous microfossils consist of only radiolarians and sponge spicules. No diatoms or silicoflagellates are seen. In Core 1 (Sections 1 and core catcher), sponge spicules are few and broken. Radiolarians are very rare with fine, thin-walled skeletons indicating considerable dissolution.

Cores 2 through 46 are barren.

In Section $541-47, C C$, very few and very badly preserved radiolarian specimens occur. No speciation is possible. In Cores 48 to 50 radiolarians are very rare to abundant, occurring in moderately well preserved (with little dissolution but common breakage), diverse assemblages. Orosphaerid fragments are common. Using the zonation of Riedel and Sanfilippo (1978), emend. Sanfilippo and Riedel (in press), radiolarians range from the Calocycletta costata Zone to the Stichocorys delmontensis Zone of the early Miocene.

Samples 541-48-5, 105-107 cm through 541-50-1, $120-122 \mathrm{~cm}$ are assigned to the Calocycletta costata Zone. The following species occur (except in Samples 541-49-1, 10-12 cm through 541-49-3, 35-37 cm, where specimens are poorly preserved):

$$
\begin{array}{ll}
\text { Calocycletta costata } & \text { Stichocorys wolffii } \\
\text { Calocycletta virginis } & \text { Cyrtocapsella cornuta } \\
\text { Stichocorys delmontensis } & \text { Dorcadospyris dentata }
\end{array}
$$

Lychnocanoma elongata is absent.

Samples 541-50-3, 12-14 cm through Section 541$50, \mathrm{CC}$ are assigned to the Stichocorys delmontensis Zone due to the appearance of $L$. elongata and Dorcadospyris ateuchus and the disappearance of Calocycletta costata and S. wolffii. Theocyrtis annosa is absent. The following species dominate the assemblage:
Calocycletta virginis Cyrtocapsella cornuta Cyrtocapsella tetrapera
Dorcadospyris ateuchus Lychnocanoma elongata Stichocorys delmontensis 
Specimens of $S$. delmontensis appear almost identical with previous specimens of $S$. wolffii, differing only in a slightly more porous ( $>6$ pores/visible half) thorax.

The Stichocorys wolffii Zone itself is absent, perhaps due to poor recovery in Core $50(39 \%)$ and the resulting hiatus between Sections 1 and 3.

\section{Foraminifers}

Drilling at Site 541 provided sediments that are rich in planktonic foraminifers from the upper part of the Miocene to the Quaternary. Most of the sediments from the middle Miocene through most of the upper Miocene are barren of foraminifers. Two tectonic units (Units A and B) are recognized at Site 541. Tectonic Unit A overlies Tectonic Unit B and is separated from it by a reverse fault. Tectonic Unit A is approximately $276 \mathrm{~m}$ thick and consists of upper Miocene to Quaternary sediments. Tectonic Unit B is approximately $184 \mathrm{~m}$ thick and consists of lower Miocene to lower Pliocene sediments. Planktonic foraminifers are present only in the upper $189.5 \mathrm{~m}$ of Tectonic Unit A and in the upper $69 \mathrm{~m}$ of Tectonic Unit B.

Samples 541-1-1, 60-62 cm through 541-8-3, 68-70 $\mathrm{cm}$ are assigned to the Quaternary, Zones N22 to N23 of Blow (1969). Globorotalia (G.) truncatulinoides truncatulinoides (d'Orbigny), Sphaeroidinella dehiscens dehiscens (Parker and Jones), Globigerinoides ruber (d'Orbigny), G. sacculifer (Brady), and Neogloboquadrina dutertrei (d'Orbigny) are some of the dominant forms found throughout this interval. The sediments from Samples $541-8-4,39-41 \mathrm{~cm}$ to $541-11-3,131-133 \mathrm{~cm}$ are assigned to Zone N22 on the basis of the occurrence of Globigerinoides obliquus obliquus Bolli, Globorotalia (T.) tosaensis Takayanagi and Saito, and $G$. (G.) truncatulinoides truncatulinoides. The first occurrence of $G$. (T.) tosaensis occurs in Section 541-10,CC.

The samples from $541-11-2,67-71 \mathrm{~cm}$ to $541-11-3$, $131-133 \mathrm{~cm}$ are assigned to Zone N22 on the occurrence of $G$. (G.) truncatulinoides truncatulinoides. The first downhole occurrence (extinction datum) of Globigerinoides obliquus extremus Bolli and Bermuda is recorded in Sample 541-11-2, 67-71 cm. The extinction datum of $G$. obliquus extremus marks the top of Zone PL6 of Berggren (1973); Zone PL6 marks the top of the upper Pliocene, as reported by Berggren (1973). However, Blow (1969) places the Pliocene/Pleistocene boundary immediately below Zone N22. The placement of the Pliocene below Sample 541-11-3, 131-133 cm is in agreement with the nannofossil evidence (Bergen, this volume).

The interval from Core 11, Section 4 to Sample 541$14-7,35-37 \mathrm{~cm}$ is assigned to the upper Pliocene Zone N21. Diagnostic foraminifers within this interval are $G$. obliquus extremus, Globorotalia (T) tosaensis, $G$. (G.) miocenica Palmer, G. (G.) multicamerata Cushman and Jarvis, Globoquadrina altispira altispira Cushman and Jarvis, and G. altispira globosa Bolli. The extinction datum of Globorotalia $(G$.) miocenica (above Sample 54113-1, 70-72 cm) marks the top of Zone PL5 of Berggren. The top of Berggren's Zone PL4 is placed above Sample 541-14-2, 74-76 cm on the first downhole occur- rence of $G$. (G.) multicamerata and Globoquadrina altispira altispira.

Sediments assignable to the basal zone (Zone PL3 of Berggren, i.e., N19 to N20 of Blow) of the upper Pliocene are seen from Section 541-14,CC to Sample 541-16-5, 75-77 cm. Sphaeroidinella dehiscens dehiscens and Sphaeroidinellopsis subdehiscens paenedehiscens Blow are found within this interval.

The lower/upper Pliocene boundary is placed below Sample 541-16-5, 75-77 cm and above Sample 541-16-6, $75-77 \mathrm{~cm}$. The extinction datum of Globorotalia $(G$.) margaritae Bolli and Bermudez above Sample 541-16-6, 75-77 $\mathrm{cm}$ defines the top of the lower Pliocene Zone PL2 of Berggren. The placement of the top of the lower Pliocene on the basis of the nannofossil evidence is at Sample 541-16-5, 13-14 cm.

The section from Sample 541-16-6, 75-77 cm to Sample $541-18-2,70-72 \mathrm{~cm}$ is assigned to that part of Zone N19 of Blow below the $G$. (G.) margaritae extinction datum.

Sediments from Sample 541-18-3, 70-72 cm to Section 541-22,CC contain specimens of the foraminifer Globigerina nepenthes Todd and Sphaeroidinellopsis subdehiscens paenedehiscens. They are assignable to that part of Zone N19 (i.e., PL1 of Berggren) that occurs below the extinction datum of $G$. nepenthes.

The boundary between the upper Miocene and the lower Pliocene cannot be determined at this site with the available foraminiferal evidence. However, on the basis of the nannofossil evidence (Bergen, this volume) the Miocene/Pliocene boundary occurs at the base of Core 22 , Section 4 . The sediments from Cores 23 to 24 are assigned to the upper Miocene. The samples from Core 25 to Sample 541-30-6, $57-59 \mathrm{~cm}$ are barren of foraminifers or contain very sparse occurrences of foraminifers. This interval is no older than late Miocene.

The interval from Samples 541-30-7, 57-59 cm (top of Tectonic Unit B) to $541-31-2,70-72 \mathrm{~cm}$ is assignable to the upper Pliocene Zone N21 of Blow (i.e., PL4 of Berggren) because of the occurrence of Globorotalia (G.) multicamerata and Globoquadrina altispira altispira.

The interval from Samples 541-31-3, 70-72 $\mathrm{cm}$ to $541-32-4,70-72 \mathrm{~cm}$ is assignable to Zone N19 to N20 (i.e., PL3 of Berggren). Specimens of Sphaeroidinellopsis subdehiscens paenedehiscens and Sphaeroidinella dehiscens dehiscens are present throughout.

The lower/upper Pliocene boundary is placed above Sample 541-32-5, $85-87 \mathrm{~cm}$, where rare specimens of Globorotalia $(G$.) margaritae are found. The interval from Sample $541-32-5,85-87 \mathrm{~cm}$ to Core 34 is assigned to that part of Zone N19 (i.e., PL2 of Berggren) below the extinction of $G$. $(G$.) margaritae.

The boundary of the lower Pliocene Zones PL1/PL2 of Berggren is placed above Section 541-34,CC. Globigerina nepenthes is common in Section 541-34,CC. Its extinction marks the top of Zone PL1.

The interval below Section 541-34,CC to Sample 541$37-4,70-72 \mathrm{~cm}$ is interpreted as upper Miocene to lower Pliocene. These sediments contain a sparse foraminiferal assemblage dominated by G. nepenthes and Sphae- 
roidinellopsis subdehiscens paenedehiscens. The first definite upper Miocene sediments occur at the base of Core 36 on the basis of the nannofossil evidence (Bergen, this volume).

The sediments from Sample $541-37-5,68-70 \mathrm{~cm}$ to Section 541-42,CC are barren of foraminifers or contain a sparse occurrence of foraminifers.

The sediments below Section 541-42,CC are barren of foraminifers.

\section{PALEOENVIRONMENT}

The following environmental analysis is based mainly on the occurrence and preservation of planktonic foraminifers. Calcareous nannofossils and smear slides also provided additional data. According to Wright (this volume), the calcite compensation depth (CCD) at Site 541 is around a depth of about $5200 \mathrm{~m}$. The lysocline (depth of increasing dissolution) of planktonic foraminifers occurs at the estimated level of 4800 to $4850 \mathrm{~m}$ (Berger, 1979). Criteria for estimating the depth of deposition in relationship to the CCD level are presence above and absence below (1) surface dwellers (spinose species), (2) thin-shelled juveniles, and (3) thin-shelled (transparent) adult specimens that calcify mainly in deeper water. Criteria for dissolution effects are (1) pore widening (surface dwellers), (2) dissolved keel regions of globorotalid forms, and (3) isolated chambers or chamber pieces (Berger, 1968). According to data from recent tropical to subtropical environments (Parker and Berger, 1971; Thunell and Honjo, 1981), planktonic foraminifers can be grouped as follows:

\begin{tabular}{|c|c|}
\hline Less resistant & More resistant \\
\hline obigerina bullo & Orbulina uni \\
\hline G. falconensis & Globorotalia truncatulinoides \\
\hline G. aequilateralis & and related species \\
\hline Orbulina universa & Globigerinoides conglobatus \\
\hline (thin shells) & Neogloboquadrina dutertrei and \\
\hline $\begin{array}{l}\text { Globigerinoides ruber } \\
\text { pink and white }\end{array}$ & $\begin{array}{l}\text { related species } \\
\text { Pulleniatina obliquiloculata }\end{array}$ \\
\hline G. sacculifer & Globorotalia crassaformis \\
\hline $\begin{array}{l}\text { Globorotalia menardii } \\
\text { (keeled globorota- } \\
\text { lids, thin shelled) }\end{array}$ & $\begin{array}{l}\text { G. menardii (thick shelled) and } \\
\text { related species } \\
\text { G. tumida }\end{array}$ \\
\hline $\begin{array}{l}\text { Juveniles of most } \\
\text { species }\end{array}$ & $\begin{array}{l}\text { Globigerina nepenthes } \\
\text { Sphaeroidinella dehiscens and } \\
\text { related species }\end{array}$ \\
\hline
\end{tabular}

Most species of the less resistant to dissolution group are surface dwellers (upper $50 \mathrm{~m}$ of the water column) or species that may migrate as deep as $400 \mathrm{~m}$ for reproduction. For example, $O$. universa reproduces normally in shallow water (upper $150 \mathrm{~m}$ ), but some of the existing population may migrate to deeper water for reproduction while they are still calcifying and thus develop thicker shells. Hardly any dissolution takes place during settlement to the lysocline (Berger, 1970). Below the lysocline, differential dissolution of the foraminifers causes assemblages of low diversity of enriched thick-shelled specimens. "Assemblages" deposited close to the CCD are nearly monospecific, consisting of $S$. dehiscens $(S$. paenedehiscens) and its fragments. Sometimes keel fragments and other indistinguishable pieces are observable.
Those samples are enriched in the more resistant benthic foraminifers.

\section{Tectonic Unit A}

Most samples from Site 541 containing calcareous fossils were deposited at or below the lysocline. Samples from Cores 1 and 2 show slight dissolution of all species in a cold-water influenced assemblage (e.g., Globigerina bulloides, Globorotalia inflata, G. truncatulinoides). However, the less resistant shelled Globigerinoides ruber are still present. The robustness of their shells highly depends on the amount of calcite they secrete just prior to reproduction (Bé, 1980). A tectonically displaced section (Sample 541-4-1, 50-70 cm) of the Pliocene characterizes a spike of a badly dissolved assemblage. A spike at the base of Core 2 seems to be caused by gravity-flow deposits. The sample contains abundant quartz grains and a mixture of rather well and poorly preserved foraminifers. The sediments immediately below contain a rather well preserved assemblage. The tropical to subtropical assemblage in Core 3 shows slightly more dissolution. Chambers and chamber fragments are common; isolated keels are absent, and G. ruber has lost its pinkish color (pigment has been dissolved). Similar examples of transported material by means of gravity flow can be seen in Core 4, Section 3 to Core 6 and the core catcher of Core 4. In contrast to Core 2, these samples contain more thick-shelled specimens that appear to be concentrated by differential dissolution (e.g., Sphaeroidinella dehiscens or thick-shelled Orbulina universa). Core 4, Sections 5 and 6 contain a rather well preserved tropical assemblage that seems to be deposited in situ. Increasing dissolution is obviously seen in Cores 5 and 6 . A certain cold-water faunistic influence is observed in Core 5, Section 3, as indicated by some specimens of Globigerina bulloides, Globorotalia inflata, and small forms of Neogloboquadrina cf. pachyderma, whereas Section 541-6,CC exhibits only a few shell fragments. Thus the sediment has been deposited below the CCD.

Decreasing dissolution occurs in Cores 7 and 8 toward the end of the lower part of the Pleistocene and is followed by a sequence of cores containing rather well preserved tropical foraminiferal assemblages. The rapid decrease of dissolution in Cores 7 and 8 coincides with the boundary between lithologic Units 1 and 2 . The best preservation is seen in Cores 9 through 11, indicating sedimentation above or at the lysocline level. More detailed studies reveal a fluctuating CCD relative to the seafloor and coinciding with glacial or interglacial phases (see Hemleben, this volume). A spike below the Pleistocene/Pliocene boundary appears again to be due to gravity-flow deposits indicated by a rather large amount of fragments in the fine fraction $(>63 \mu \mathrm{m})$ and quartz grains. Core 13, Section 5 through Core 14, Section 6 show rather well preserved assemblages of a warm water (tropical) environment. Beginning with Core 17, Section 2 , dissolution increases slowly with drilling depth but is interrupted by several gravity-flow deposits showing generally better preservation. Core 23 is characterized by rapidly increasing dissolution and Core 24 reaches the 
CCD, which coincides with the boundary of Lithologic Units 3 and 4 . Core 25 through Core 30 , Section 6 are mostly barren of planktonic foraminifers and contain only fish bone debris and some shark teeth. Thus sedimentation took place below or at the level of the CCD. Core 28, Section 4 through Section 541-28,CC contain shell fragments and some highly resistant species such as Globigerina nepenthes. Most samples showing none or only rare fragments of planktonic foraminifers still contain some benthic shells. This clearly shows (1) the greater resistance of benthic foraminifers to dissolution, and (2) the level of sedimentation being close to the CCD. Whether the sharp increase of dissolution is influenced by the rising CCD, as Berger (1977) has suggested, or whether it is due to subsidence cannot be decided here because we need more data. In addition, the poor preservation in Lithologic Unit 3 may be influenced by bioturbation (see the section on Bioturbation, this chapter).

\section{Tectonic Unit B}

The changes in fossil preservation in sediments in Tectonic Unit B cannot be directly compared to its equivalent unit in Tectonic Unit A. The preservation in Unit B is poor in comparison to that in Unit A.

This difference may be influenced by bioturbation and compaction and by minor tectonic movements. Collapsed specimens occur more often than in Tectonic Unit A. Assemblages of Cores 31 through 34 are rather wellpreserved, but the juveniles and thin-shelled specimens of most species are absent. However, Core 34, Section 2 shows an exceptional well-preserved assemblage of tropical species. Within Core 37, Section 1 the "foraminiferal CCD" has been reached. Core 39 through Core 42, Section 6 are deposited close to-either slightly above or below-the CCD, as documented by the presence or absence, respectively, of fragments and the occurrence of a few benthic foraminifers. Cores 42, Section 7 through 50 are barren of calcareous fossils and are thus deposited below the CCD. This becomes more evident as radiolarians appear in the core catcher of Core 47. Comparing Cores 22 through 30 of Unit A with Cores 37 through 42 of Unit B, it appears that the latter core sequence may have been deposited slightly deeper with respect to the CCD.

Few benthic foraminifers occur in most samples but have not been studied in detail. However, all observed specimens are deep-water (abyssal) species and normally better preserved than the planktonic foraminifers. This phenomenon was noted by Parker and Berger (1971) and Schnitker (1979) on Leg 48. Shallow-water species are only observed in one gravity-flow deposit (Cores 4-6). This observation indicates that the source of the gravity-flow deposits is not from a continental or island arc slope. These sediments may have originated from the upper part of the Barbados Rise.

In considering the depth position of the CCD several different factors must be taken into account: (1) uplift or subsidence, (2) changes in the water mass system (e.g., current system), (3) climatic changes, and (4) current transport of calcareous particles below the CCD.
However, comparing abundances of tropical and subtropical faunal composition (e.g., occurrence of Globorotalia menardii versus G. truncatulinoides), excluding gravity-flow deposits and tectonically displaced sediments, shows that the CCD fluctuated during the Quaternary, reflecting the glacial and interglacial phases. Carbonate bomb data, calcareous nannofossils, and foraminiferal abundances in the cores support the results that indicate a trend toward a rising CCD during the Miocene.

\section{PORE-FLUID CHEMISTRY}

Eleven samples were taken for pore-fluid chemistry at Site 541. Three additional samples were obtained with the in situ samples. The data are listed in Gieskes et al. (this volume), where they are plotted versus depth and summarized. The second in situ sample did not succeed in displacing the fresh water that is normally kept in the sampler core prior to sampling, hence is somewhat diluted, giving reductions in salinity and chlorinity. The major trends of the data with increasing depths are (1) a drop in alkalinity, (2) erratic salinity values despite monotonically diminishing chlorinity, and (3) a marked decrease in $\mathrm{Mg}^{2+}$ and a complementary increase in $\mathrm{Ca}^{2+}$. The changes in alkalinity, $\mathrm{Mg}^{2+}$, and $\mathrm{Ca}^{2+}$ result from exchange of $\mathrm{Ca}^{2+}$ in volcanic glass in the sediments with $\mathrm{Mg}^{2+}$ to form clay minerals, reactions which consume alkalinity. Other data (heat flow, physical properties, fluid pressure measurements) at both Sites 541 and 542 indicate that pore fluids may migrate along fractures and faults in the sediments from the major shear zone, or décollement, reached at Site 541. Some of the porefluid gradients at Site 541, therefore, may have been influenced by tectonically induced pore-fluid migration.

\section{ORGANIC GEOCHEMISTRY}

In view of the oil production on Barbados Island to the south, the hydrocarbon geochemistry of Leg 78A sites was observed with much interest and considerable caution. Total organic carbon content of Hole 541 sediments was very low, decreasing from about $0.24 \%$ in the shallowest cores to about $0.06 \%$ at total depth of about $453 \mathrm{~m}$. Hydrocarbon gases were dispersed at background levels in the sediments. Concentrations of $\mathrm{C}_{1}$ to $\mathrm{C}_{6} \mathrm{hy}-$ drocarbons were estimated at 10 to 700 standard volumes of gas per $10^{9}$ volumes of sediment, increasing regularly with increasing depth of burial.

In general, the low organic carbon content reflects poor organic matter productivity and preservation in the deep sea environment. Low hydrocarbon content reflects absence of hydrocarbon precursors deposited and preserved with the sediments.

\section{PHYSICAL PROPERTIES PROCEDURES}

Sonic velocity, wet-bulk density, porosity, water content (percent wet weight), shear strength, and thermal conductivity were determined (Table 3 ).

\section{Compressional Acoustic Velocity}

Velocities were measured using the Hamilton Frame device (Boyce, 1976). In the upper part of the hole, soft 
Table 3. Summary of physical properties for Site 541.

\begin{tabular}{|c|c|c|c|c|c|c|c|c|c|c|c|c|c|}
\hline \multirow{4}{*}{$\begin{array}{c}\text { Sample } \\
\text { (core-section, } \\
\text { interval in } \mathrm{cm} \text { ) }\end{array}$} & \multirow{4}{*}{$\begin{array}{l}\text { Sub-bottom } \\
\text { depth } \\
\text { (m) }\end{array}$} & \multicolumn{6}{|c|}{ 2-min. GRAPE } & \multirow{2}{*}{\multicolumn{3}{|c|}{ Gravimetric }} & \multirow{4}{*}{$\begin{array}{c}\text { Acoustic } \\
\text { impedance } \\
\left(\times 10^{5} \mathrm{~g} / \mathrm{cm}^{2} \mathrm{~s}\right) \\
\underset{\mathrm{V}^{\mathrm{a}}}{ }\end{array}$} & \multirow{4}{*}{$\begin{array}{l}\text { Shear } \\
\text { strength } \\
(\mathrm{kPa})\end{array}$} & \\
\hline & & & & & & & & & & & & & \\
\hline & & $(\mathrm{km}$ & & & & (\%) & & $\begin{array}{l}\text { Wet-bulk } \\
\text { density }\end{array}$ & Porosity & Water & & & $\begin{array}{l}\text { conductivity } \\
{\left[\times 10^{-3} \text { (cal/ }\right.}\end{array}$ \\
\hline & & $\mathrm{H}^{\mathrm{a}}$ & $v^{a}$ & $\mathrm{H}^{\mathrm{a}}$ & $v^{a}$ & $\mathrm{H}^{\mathrm{a}}$ & $v^{a}$ & $\left(\mathrm{~g} / \mathrm{cm}^{3}\right)$ & $(\%)$ & $(\%)$ & & & \\
\hline $1-1,29-31$ & 0.3 & & & & & & & & & & & 11.53 & \\
\hline $1-1,49-51$ & 1.5 & 1.491 & & 1.35 & & 80.6 & & 1.42 & 69.5 & 50.0 & 2.12 & & \\
\hline $2-5,48-51$ & 7.5 & 1.482 & & 1.21 & & 89.0 & & 1.41 & 77.9 & 56.5 & 2.09 & & \\
\hline $2-5,86-89$ & 7.9 & & & & & & & & & & & 11.53 & \\
\hline $2-5,100-101$ & 8.0 & & & & & & & & & & & & 2.213 \\
\hline $\begin{array}{l}2-6,71-74 \\
2-6,96-98\end{array}$ & $\begin{array}{l}9.2 \\
9.5\end{array}$ & 1.492 & & 1.32 & & 82.4 & & 1.41 & 75.5 & 54.7 & 2.10 & 24.71 & \\
\hline $3-1,83-86$ & 11.4 & 1.506 & & 1.59 & & 66.3 & & 1.51 & 70.8 & 48.2 & 2.27 & & \\
\hline $3-3,56-59$ & 14 & & & & & & & & & & & 29.24 & \\
\hline $3-4,68-71$ & 15.6 & 1.537 & & 1.71 & & 59.1 & & 1.70 & 64.6 & 38.9 & 2.61 & & \\
\hline $3-4,81-84$ & 15.8 & & & & & & & & & & & 26.3 & \\
\hline $4-1,69-72$ & 20.7 & 1.533 & & 1.69 & & 60.3 & & 1.68 & 65.8 & 40.2 & 2.58 & & \\
\hline $4-4,93-96$ & 25.5 & 1.496 & & 1.59 & & 66.3 & & 1.61 & 64.0 & 40.6 & 2.41 & & 3.475 \\
\hline $\begin{array}{l}4-4,110 \\
4-4,123-126\end{array}$ & $\begin{array}{l}25.5 \\
25.7\end{array}$ & & & & & & & & & & & 47.7 & $3.4 / 5$ \\
\hline $4-6,84-87$ & 28.3 & & & & & & & & & & & 39.53 & \\
\hline $5-2,7-10$ & 31 & 1.559 & & 1.73 & & 57.9 & & 1.63 & 64.1 & 40.2 & 2.54 & & \\
\hline $5-3,70-72$ & 33.2 & & & & & & & & & & & 78.24 & \\
\hline $6-1,63-65$ & 39.6 & & & & & & & & & & & 37.47 & \\
\hline $6-1,68-70$ & 39.7 & 1.537 & & 1.66 & & 62.1 & & 1.66 & 60.9 & 37.6 & 2.55 & & \\
\hline $7-2,109-112$ & 51 & 1.514 & 1.541 & 1.72 & & 58.5 & & 1.67 & 63.2 & 38.9 & 2.57 & & \\
\hline $7-3,53-56$ & 52 & 1.535 & 1.536 & 1.58 & & 66.9 & & 1.68 & 62.1 & 37.9 & 2.56 & & \\
\hline $\begin{array}{l}7-3,82-86 \\
7-3,117\end{array}$ & $\begin{array}{l}52.3 \\
52.5\end{array}$ & & & & & & & & & & & 42.83 & 3.119 \\
\hline $7-6,86-89$ & 56.9 & & & & & & & & & & & 60.12 & \\
\hline $8-1,69-71$ & 58.7 & 1.516 & 1.536 & 1.72 & & 58.5 & & 1.70 & 61.1 & 36.8 & 2.61 & & \\
\hline $8-1,79-82$ & 58.8 & & & & & & & & & & & 44.47 & \\
\hline $8-4,76-79$ & 63.3 & & & & & & & & & & & 27.17 & \\
\hline $\begin{array}{l}8-5,42-46 \\
8-7,45-48\end{array}$ & $\begin{array}{l}64.5 \\
67.5\end{array}$ & 1.554 & 1.535 & 1.72 & & 58.5 & & 1.71 & 59.6 & 35.7 & 2.62 & 87.30 & \\
\hline $8-7,49-53$ & 67.5 & 1.509 & 1.528 & 1.66 & & 62.1 & & 1.65 & 63.3 & 39.4 & 2.52 & & \\
\hline $9-2,53-56$ & 69.5 & & & & & & & & & & & 72.48 & \\
\hline $9-4,56-59$ & 72.6 & & & & & & & & & & & 46.04 & \\
\hline $9-6,89-91$ & 75.9 & 1.535 & 1.626 & 1.72 & & 58.5 & & 1.71 & 60.3 & 36.0 & 2.78 & & \\
\hline $10-1,100-102$ & 78.0 & & & & & & & & & & & 53.53 & \\
\hline $10-2,79-82$ & 79.3 & 1.566 & 1.598 & 1.69 & & 60.3 & & 1.72 & 59.6 & 35.6 & 2.75 & & 3287 \\
\hline $\begin{array}{l}10-3,111 \\
10-3,117-118\end{array}$ & $\begin{array}{l}81.1 \\
81.2\end{array}$ & & & & & & & & & & & 49.83 & 3.287 \\
\hline $10-4,50-53$ & 82 & 1.550 & 1.539 & 1.75 & & 56.7 & & 1.69 & 61.2 & 37.0 & 2.60 & & \\
\hline $10-4,60-63$ & 82.1 & & & & & & & & & & & 64.24 & \\
\hline $10-6,129-131$ & 85.8 & & & & & & & & & & & 70.83 & \\
\hline $10-7,16-19$ & 86.2 & & & & & & & & & & & 45.71 & \\
\hline $11-1,90-93$ & 87.4 & & & & & & & & & & & 57.65 & \\
\hline $11-1,99-102$ & 87.5 & 1.562 & 1.568 & 1.76 & & 56.1 & & 1.71 & 60.2 & 36.0 & 2.68 & & \\
\hline $11-4,54-57$ & 91.5 & 1.591 & 1.598 & 1.79 & & 54.3 & & 1.77 & 57.1 & 33.0 & 2.83 & & \\
\hline $\begin{array}{l}11-4 ; 74-77 \\
11-4 ; 11-113\end{array}$ & 91.7 & & & & & & & & & & & $\begin{array}{l}72.89 \\
80.30\end{array}$ & \\
\hline $12-1,110-113$ & 97.1 & & & & & & & & & & & 90.60 & \\
\hline $12-1,118-122$ & 97.2 & 1.561 & 1.581 & 1.85 & & 50.8 & & 1.79 & 56.3 & 32.1 & 2.83 & & \\
\hline $12-1,133$ & 97.3 & & & & & & & & & & & & 3.924 \\
\hline $12-2,25-28$ & 97.8 & & & & & & & & & & & 107.07 & \\
\hline $12-7,12-15$ & 105.1 & 1.601 & 1.596 & 1.83 & & 51.9 & & 1.76 & 57.3 & 33.4 & 2.81 & & \\
\hline $12-7,19-22$ & 105.2 & & & & & & & & & & & 76.59 & \\
\hline $\begin{array}{l}13-1,89-92 \\
13-1,118-121\end{array}$ & $\begin{array}{l}106.4 \\
106.6\end{array}$ & 1.592 & 1.618 & 1.71 & & 59.1 & & 1.69 & 61.7 & 37.4 & 2.73 & 81.95 & \\
\hline $13-3,123-125$ & 109.7 & & & & & & & & & & & 93.07 & \\
\hline $13-5,41-44$ & 111.9 & 1.598 & 1.608 & 1.86 & & 50.1 & & 1.77 & 57.8 & 33.4 & 2.85 & & \\
\hline $13-5,91-94$ & 112.4 & & & & & & & & & & & 83.18 & \\
\hline $13-7,25-28$ & 114.7 & 1.661 & 1.596 & 1.85 & & 50.7 & & 1.78 & 56.8 & 32.6 & 2.84 & & \\
\hline $\begin{array}{l}14-1,87-90 \\
14-3,40-43\end{array}$ & $\begin{array}{l}115.9 \\
118.4\end{array}$ & 1.556 & 1.551 & 1.02 & 1.88 & 49.0 & & 1.78 & 57.4 & 33.0 & 2.76 & 84.01 & \\
\hline $14-5,70-73$ & 121.7 & 1.559 & 1.574 & 1.91 & 2.05 & 47.2 & 38.8 & 1.77 & 57.7 & 33.4 & 2.79 & & \\
\hline $14-5,97-100$ & 122 & & & & & & & & & & & 51.06 & \\
\hline $\begin{array}{l}15-1,80-83 \\
15-3,71-74\end{array}$ & $\begin{array}{l}125.3 \\
128.2\end{array}$ & 1.541 & 1.539 & 1.86 & 1.81 & 50.2 & 53.1 & 1.74 & 58.6 & 34.4 & 2.68 & 90.60 & \\
\hline $15-5,41-44$ & 130.9 & 1.581 & 1.575 & 1.81 & 1.86 & 53.1 & 50.2 & 1.80 & 55.4 & 31.5 & 2.84 & 90.60 & \\
\hline $15-5,74-77$ & 131.2 & & & & & & & & & & & 98.83 & \\
\hline $15-2,110$ & 136.6 & & & & & & & & & & & & 3.287 \\
\hline $16-3,58-60$ & 137.6 & 1.581 & 1.589 & 1.43 & 1.83 & 75.8 & 51.9 & 1.81 & 55.1 & 31.2 & 2.88 & & \\
\hline $16-3,68-71$ & 137.7 & & & & & & & & & & & $>128.83$ & \\
\hline $16-5,100-103$ & 141 & & & & & & & & & & & 116.95 & \\
\hline $16-6,50-52$ & 142 & 1.585 & 1.568 & 1.83 & 1.80 & 51.9 & 53.7 & 1.77 & 57.3 & 33.2 & 2.78 & & \\
\hline $17-2,35-38$ & 145.4 & 1.581 & 1.569 & 1.77 & 1.81 & 55.5 & 53.1 & 1.79 & 56.1 & 32.1 & 2.81 & & \\
\hline $17-2,44-47$ & 145.5 & & & & & & & & & & & 102.13 & \\
\hline $17-4,68-71$ & 148.7 & & & & & & & & & & & $>125.19$ & \\
\hline $17-5,85-88$ & 150.4 & 1.617 & 1.563 & & & & & 1.73 & 59.0 & 35.0 & 2.70 & & \\
\hline $\begin{array}{l}18-1,97-100 \\
18-1,108-111\end{array}$ & $\begin{array}{l}154 \\
154.1\end{array}$ & 1.572 & 1.545 & 1.89 & 1.72 & 48.4 & 58.5 & 1.68 & 61.6 & 37.6 & 2.60 & 121.89 & \\
\hline
\end{tabular}


Table 3. (Continued).

\begin{tabular}{|c|c|c|c|c|c|c|c|c|c|c|c|c|c|}
\hline \multirow{4}{*}{$\begin{array}{c}\text { Sample } \\
\text { (core-section, } \\
\text { interval in } \mathrm{cm} \text { ) }\end{array}$} & \multirow{4}{*}{$\begin{array}{l}\text { Sub-bottom } \\
\text { depth } \\
\text { (m) }\end{array}$} & \multicolumn{6}{|c|}{ 2-min. GRAPE } & \multirow{2}{*}{\multicolumn{3}{|c|}{ Gravimetric }} & \multirow{4}{*}{$\begin{array}{c}\text { Acoustic } \\
\text { impedance } \\
\left(\times 10^{5} \mathrm{~g} / \mathrm{cm}^{2} \mathrm{~s}\right) \\
\mathrm{V}^{\mathrm{a}}\end{array}$} & \multirow{4}{*}{$\begin{array}{c}\text { Shear } \\
\text { strength } \\
(\mathrm{kPa})\end{array}$} & \\
\hline & & & & Wet- & bulk & & & & & & & & hermal \\
\hline & & & & & & $(\%)$ & & $\begin{array}{c}\text { Wet-bulk } \\
\text { density }\end{array}$ & Porosity & Water & & & $\begin{array}{l}\text { conductivity } \\
{\left[\times 10^{-3} \text { (cal/ }\right.}\end{array}$ \\
\hline & & $\mathrm{H}^{\mathrm{a}}$ & $v^{a}$ & $\mathbf{H}^{\mathrm{a}}$ & $v^{a}$ & $\mathrm{H}^{\mathrm{a}}$ & $\mathrm{v}^{\mathrm{a}}$ & $\left(\mathrm{g} / \mathrm{cm}^{3}\right)$ & (\%) & $(\%)$ & & & $\mathrm{cm} \cdot \mathrm{s} \cdot \mathrm{deg})]$ \\
\hline $18-3,113-116$ & 157.1 & & & & & & & & & & & $>122.72$ & \\
\hline $18-3,122-126$ & 157.2 & 1.594 & 1.602 & 1.78 & 1.82 & 54.9 & 52.5 & 1.81 & 54.6 & 38.9 & 2.90 & & \\
\hline $18-5,106-109$ & 160.1 & & & & & & & & & & & 126.01 & \\
\hline $19-1,83-85$ & 163.3 & & & & & & & & & & & 116.95 & \\
\hline $19-1,89-92$ & 163.4 & 1.577 & 1.593 & 1.87 & 1.80 & 49.6 & 53.7 & 1.84 & 53.5 & 29.8 & 2.93 & & \\
\hline $19-3,41-44$ & $\begin{array}{l}165.9 \\
169.1\end{array}$ & & & & & & & & & & & $>118.60$ & \\
\hline $19-5,56-59$ & $\begin{array}{l}169.1 \\
169.2\end{array}$ & 1.589 & 1.610 & 1.68 & 1.78 & 60.9 & 54.9 & 185 & & & 298 & $>126.01$ & \\
\hline $\begin{array}{l}19-5,64-67 \\
19-6,90-93\end{array}$ & $\begin{array}{l}169.2 \\
170.9\end{array}$ & & & & 1.78 & 60.9 & 54.9 & 1.85 & 53.0 & 29.3 & 2.98 & 115.30 & \\
\hline $20-1,62-64$ & 172.6 & & & & & & & & & & & 108.72 & \\
\hline $20-1,76-79$ & 172.8 & 1.661 & 1.662 & 1.72 & 1.75 & 58.5 & 56.7 & 1.77 & 57.1 & 33.0 & 2.94 & & \\
\hline $20-4,33-36$ & 176.9 & & & & & & & & & & & 120.25 & \\
\hline $20-4,39-43$ & 176.9 & 1.618 & 1.625 & 1.93 & 1.86 & 46.0 & 50.2 & 1.85 & 53.5 & 29.7 & 3.01 & & \\
\hline $20-6,28$ & 179.8 & & & & & & & & & & & & 2.896 \\
\hline $20-7,8-11$ & 181.1 & & & & & & & & & & & 116.95 & \\
\hline $\begin{array}{l}21-1,67-70 \\
21-1,72-76\end{array}$ & $\begin{array}{l}182.2 \\
182.2\end{array}$ & 1.608 & 1.627 & 1.89 & 1.86 & 48.4 & 50.2 & 1.86 & 52.3 & 28.7 & 3.03 & 119.42 & \\
\hline $21-2,46-49$ & 183.5 & & & & & & & 1.00 & (1) & 20.6 & (.0 & $>127.66$ & \\
\hline $21-2,51-54$ & 183.5 & 1.629 & 1.632 & 1.60 & 1.76 & 65.7 & 56.1 & 1.84 & 53.8 & 30.0 & 3.00 & & \\
\hline $21, \mathrm{CC}$ & 191 & & & & & & & & & & & & $>116.54$ \\
\hline $22-2,21-24$ & 192.7 & 1.604 & 1.618 & 1.48 & 1.93 & 72.8 & 46.0 & 1.90 & 50.7 & 27.4 & 3.07 & & \\
\hline $22-2,28-30$ & $\begin{array}{l}192.8 \\
194.5\end{array}$ & & & & & & & & & & & $>121.89$ & \\
\hline $22-3,49-52$ & $\begin{array}{l}194.5 \\
199.4\end{array}$ & 1.633 & 1.624 & 1.95 & 1.86 & 44.8 & 50.2 & & & & & 118.60 & \\
\hline 22-6, 91-94 & $\begin{array}{l}199.4 \\
199.7\end{array}$ & & & & & 44.8 & 50.2 & 1.86 & 52.2 & 28.7 & 3.02 & & \\
\hline $\begin{array}{l}22-6,119-122 \\
22-7,21-24\end{array}$ & $\begin{array}{l}199.7 \\
200.2\end{array}$ & & & & & & & & & & & $>112.83$ & \\
\hline $\begin{array}{l}22-7,21-24 \\
23-1,47-50\end{array}$ & $\begin{array}{l}200.2 \\
201 .\end{array}$ & 1.605 & 1.583 & 2.00 & 1.83 & 41.8 & 51.9 & 1.83 & 54.6 & 30.6 & 2.90 & $>150.42$ & \\
\hline $23-1,87-90$ & 201.4 & & & & & & & & & & & 115.30 & \\
\hline $23-1,70-73$ & 204.2 & & & & & & & & & & & $>109.54$ & \\
\hline $23-5,52-55$ & 207. & 1.600 & 1.602 & 1.63 & 1.84 & 61.9 & 51.3 & 1.79 & 57.0 & 32.6 & 2.87 & & \\
\hline $\begin{array}{l}23-5,61-63 \\
24-1,52-55\end{array}$ & $\begin{array}{l}207.1 \\
210.5\end{array}$ & & & & & & & & & & & $>122.72$ & \\
\hline $\begin{array}{l}24-1,52-55 \\
24-1,69-72\end{array}$ & $\begin{array}{l}210.5 \\
210.7\end{array}$ & 1.620 & 1.624 & 1.93 & 1.49 & 46.0 & 72.2 & 1.78 & 57.6 & 33.1 & 2.89 & $>126.83$ & \\
\hline $24-1,80$ & 210.8 & & & & & & & & & & & & 2.896 \\
\hline $24-4,58-60$ & 215.1 & & & & & & & & & & & $>111.19$ & \\
\hline $24-4,66-69$ & $\begin{array}{l}215.2 \\
216.8\end{array}$ & 1.674 & 1.680 & 1.79 & 1.95 & 54.3 & 44.8 & 1.86 & 54.4 & 29.9 & 3.12 & & \\
\hline & $\begin{array}{l}216.8 \\
220.5\end{array}$ & 1.565 & 1.589 & 1.61 & & & & & & & & 121.89 & \\
\hline $\begin{array}{l}25-1,101-104 \\
25-1,107-110\end{array}$ & $\begin{array}{l}220.5 \\
220.6\end{array}$ & & & 1.01 & 1.65 & 65.1 & 62.7 & 1.71 & 61.4 & 36.7 & 2.72 & & \\
\hline & 223. & 1.639 & 1.627 & 1.54 & 1.62 & 69.3 & 64.5 & 1.79 & 57.4 & 32.9 & 2.91 & $>122.72$ & \\
\hline $25-3,64-67$ & 223.1 & & & & & & & & & & & $>114.07$ & \\
\hline $25-7,18-21$ & 226.7 & & & & & & & & & & & 116.13 & \\
\hline $25-7,28-31$ & 226.8 & 1.609 & 1.621 & 1.81 & 1.77 & 53.1 & 55.5 & 1.76 & 58.5 & 33.9 & 2.85 & & \\
\hline $26-2,36-39$ & 230.9 & & & & & & & & & & & 65.89 & \\
\hline $26-2,78-80$ & 231.3 & 1.539 & & & & & & 1.62 & 65.0 & 41.1 & 2.53 & & \\
\hline $26-2,78-80$ & 231.3 & 1.561 & & & & & & 1.62 & 65.0 & 41.1 & 2.53 & & \\
\hline $26-2,78-80$ & 231.3 & & 1.562 & 1.66 & 1.63 & 62.1 & 63.9 & 1.62 & 65.0 & 41.1 & 2.53 & & \\
\hline $26-4,25-28$ & 233.8 & & & & & & & & & & & $>118.60$ & \\
\hline $26-4,68-70$ & 234.2 & 1.629 & & 1.84 & 1.64 & 51.3 & 63.3 & 1.79 & 57.7 & 33.1 & 2.84 & & \\
\hline $26-4,68-70$ & 234.2 & 1.625 & & 1.84 & 1.64 & 51.3 & 63.3 & 1.79 & 57.7 & 33.1 & 2.84 & & \\
\hline $26-4,68-70$ & 234.2 & & 1.584 & 1.84 & 1.64 & 51.3 & 63.3 & 1.79 & 57.7 & 33.1 & 2.84 & & \\
\hline $27-1,107-110$ & 239.6 & 1.606 & & 1.45 & 1.46 & 74.6 & 74.0 & 1.53 & 47.1 & 31.7 & 2.52 & & \\
\hline $27-1,107-110$ & 239.6 & 1.639 & & 1.45 & 1.46 & 74.6 & 74.0 & 1.53 & 47.1 & 31.7 & 2.52 & & \\
\hline $\begin{array}{l}27-2,119-122 \\
27-5,60-63\end{array}$ & $\begin{array}{l}241.2 \\
245.1\end{array}$ & 1.632 & 1.598 & 1.82 & 1.86 & 52.5 & & 1.78 & 58.0 & 33.4 & 2.84 & $>112.01$ & \\
\hline $\begin{array}{l}27-5,60-63 \\
27-5,86-89\end{array}$ & $\begin{array}{l}245.1 \\
245.4\end{array}$ & & & & & 32.3 & 50.2 & 1.78 & 30.0 & 33.4 & 2.04 & $>108.72$ & \\
\hline $28-1,90-93$ & 248.9 & 1.578 & 1.591 & 1.80 & 1.82 & 53.7 & 52.5 & 1.77 & 58.4 & 33.7 & 2.82 & & \\
\hline $28-2,86-86$ & 250.4 & & & & & & & & & & & $>120.25$ & \\
\hline $28-4,34-37$ & 252.9 & 1.627 & 1.598 & 1.79 & 1.77 & 54.3 & 55.5 & 1.77 & 58.1 & 33.6 & 2.83 & & \\
\hline $28-5,88-91$ & 254.9 & & & & & & & & & & & $>107.06$ & \\
\hline $\begin{array}{l}28-5,108-111 \\
29-2,30-33\end{array}$ & $\begin{array}{l}255.1 \\
259.3\end{array}$ & 1.665 & 1.691 & 1.90 & 1.95 & 47.8 & 44.8 & $\begin{array}{l}1.88 \\
1.75\end{array}$ & $\begin{array}{l}52.3 \\
62.0\end{array}$ & $\begin{array}{l}28.4 \\
36.2\end{array}$ & $\begin{array}{l}3.18 \\
2.87\end{array}$ & & \\
\hline $\begin{array}{l}29-2,30-33 \\
29-2,36-39\end{array}$ & $\begin{array}{l}259.3 \\
259.4\end{array}$ & 1.627 & 1.638 & 1.82 & & 52.5 & & 1.75 & 62.0 & 36.2 & 2.87 & $>107.07$ & \\
\hline $29-4,110-113$ & 263.1 & 1.557 & 1.691 & 1.82 & 1.82 & 52.5 & 52.5 & 1.80 & 56.2 & 32.0 & 3.04 & & \\
\hline $29-4,138-141$ & 263.4 & & & & & & & & & & & $>108.72$ & \\
\hline $29-6,14-17$ & 265.2 & & & & & & & & & & & $>112.01$ & \\
\hline $\begin{array}{l}30-1,86-90 \\
30-2,75-79\end{array}$ & $\begin{array}{l}267.9 \\
269.3\end{array}$ & $\begin{array}{l}1.545 \\
1.574\end{array}$ & 1.618 & 1.93 & 1.95 & 46.0 & 44.8 & 1.83 & 55.6 & 31.1 & 2.96 & & \\
\hline $30-2,79$ & 269.3 & 1.514 & 1.010 & & & & & & & & & & 2.764 \\
\hline $30-2,84-87$ & 269.4 & & & & & & & & & & & $>115.72$ & \\
\hline $30-5,103-107$ & 274. & 1.586 & 1.583 & 1.83 & 1.73 & 51.9 & 57.9 & 1.74 & 60.6 & 35.6 & 2.75 & & \\
\hline $30-5,129-131$ & 274.3 & & & & & & & & & & & $>103.77$ & \\
\hline $30-7,36-39$ & 276.4 & & & & & & & & & & & $>116.54$ & \\
\hline $31-1,125-127$ & 277.8 & & & & & & & & & & & 112.01 & \\
\hline $31-1,130-133$ & 277.8 & 1.609 & 1.575 & 1.91 & 1.86 & 47.2 & 49.8 & 1.86 & 52.2 & 28.7 & 2.93 & & \\
\hline $\begin{array}{l}31-3,119-121 \\
31-5,98-100\end{array}$ & $\begin{array}{l}280.7 \\
283.5\end{array}$ & & & & & & & & & & & $\begin{array}{r}75.55 \\
>103.77\end{array}$ & \\
\hline
\end{tabular}


Table 3. (Continued).

\begin{tabular}{|c|c|c|c|c|c|c|c|c|c|c|c|c|c|}
\hline \multirow{4}{*}{$\begin{array}{c}\text { Sample } \\
\text { (core-section, } \\
\text { interval in } \mathrm{cm} \text { ) }\end{array}$} & \multirow{4}{*}{$\begin{array}{l}\text { Sub-bottom } \\
\text { depth } \\
\text { (m) }\end{array}$} & \multicolumn{6}{|c|}{ 2-min. GRAPE } & \multirow{2}{*}{\multicolumn{3}{|c|}{ Gravimetric }} & \multirow{4}{*}{$\begin{array}{c}\text { Acoustic } \\
\text { impedance } \\
\left(\times 10^{5} \mathrm{~g} / \mathrm{cm}^{2} \mathrm{~s}\right) \\
\mathrm{V}^{\mathrm{a}}\end{array}$} & \multirow{4}{*}{$\begin{array}{l}\text { Shear } \\
\text { strength } \\
(\mathrm{kPa})\end{array}$} & \\
\hline & & & & & & & & & & & & & Thermal \\
\hline & & $\begin{array}{l}\text { velo } \\
(\mathrm{km}\end{array}$ & & & & $\begin{array}{l}\text { Poros } \\
(\%)\end{array}$ & & $\begin{array}{l}\text { Wet-bulk - } \\
\text { density }\end{array}$ & Porosity & Water & & & $\begin{array}{l}\text { conductivity } \\
{\left[\times 10^{-3}(\mathrm{cal} /\right.}\end{array}$ \\
\hline & & $\mathrm{H}^{\mathrm{a}}$ & $\mathrm{v}^{\mathrm{a}}$ & $\mathrm{H}^{\mathrm{a}}$ & $\mathrm{v}^{\mathrm{a}}$ & $\mathrm{H}^{\mathrm{a}}$ & $\mathrm{v}^{\mathrm{a}}$ & $\left(\mathrm{g} / \mathrm{cm}^{3}\right)$ & $(\%)$ & $(\%)$ & & & $\mathrm{cm} \cdot \mathrm{s} \cdot \mathrm{deg})]$ \\
\hline $31-6,111-114$ & 285.1 & 1.629 & 1.642 & 1.92 & 1.90 & 46.6 & 47.8 & 1.88 & 50.6 & 27.5 & 3.09 & & \\
\hline $31-6,135-138$ & 285.4 & & & & & & & & & & & $>115.30$ & \\
\hline $32-1,52-55$ & 286.5 & 1.636 & 1.650 & 1.82 & 1.88 & 52.5 & 49.0 & 1.87 & 51.4 & 28.2 & 3.09 & & \\
\hline $32-1,60-63$ & 286.6 & & & & & & & & & & & $>125.19$ & \\
\hline $32-3,106-109$ & 290.1 & & & & & & & & & & & $>116.13$ & \\
\hline $32-5,28-31$ & 292.3 & & & & & & & & & & & 130.95 & \\
\hline $32-5,34-37$ & 292.4 & 1.661 & 1.654 & 1.92 & 1.93 & 46.6 & 46.0 & 1.91 & 48.9 & 26.2 & 3.16 & & \\
\hline $32-6,102-105$ & 294.5 & & & & & & & & & & & 65.89 & \\
\hline $33-1,98-101$ & 296.5 & & & & & & & & & & & 122.72 & \\
\hline $33-1,104-107$ & 296.5 & 1.661 & 1.671 & & & & & 1.91 & 50.0 & 26.8 & 3.19 & & \\
\hline $33-4,82-85$ & 300.8 & & & & & & & & & & & 110.36 & \\
\hline $33-6,106-109$ & 304.1 & & & & & & & & & & & 124.36 & \\
\hline $33-7,23-26$ & 304.7 & & & & & & & & & & & 112.01 & \\
\hline $33-7,31-34$ & 304.7 & 1.716 & 1.727 & 1.85 & 1.95 & 50.7 & 44.8 & 1.92 & 48.2 & 25.7 & 3.32 & Non & \\
\hline $34-2,75-77$ & 307.3 & & & & & & & & & & & 107.07 & \\
\hline $34-2,82-86$ & 307.4 & 1.626 & 1.614 & 1.86 & 1.89 & 50.1 & 48.4 & 1.84 & 53.3 & 29.7 & 2.97 & & \\
\hline $34-2,95$ & 307.5 & & & & & & & & & & & & 2.100 \\
\hline $34-4,103-105$ & 310.5 & & & & & & & & & & & 47.77 & \\
\hline $34-6,108-112$ & 313.6 & 1.673 & 1.675 & 1.96 & 1.98 & 44.2 & 43.0 & 1.92 & 48.8 & 26.0 & 3.22 & & \\
\hline $34-6,115-118$ & 313.7 & & & & & & & & & & & $>121.89$ & \\
\hline $35-1,99-101$ & 315.5 & & & & & & & & & & & 113.66 & \\
\hline $35-4,97-99$ & 320. & & & & & & & & & & & $>121.89$ & \\
\hline $35-4,103-106$ & 320. & 1.655 & 1.625 & 1.90 & 1.90 & 47.8 & & 1.87 & 52.1 & 28.6 & 3.04 & & \\
\hline $35-6,25-28$ & 322.3 & & & & & & & & & & & $>112.83$ & \\
\hline $35-6,33-36$ & 322.3 & 1.651 & 1.638 & 1.78 & 1.95 & 54.9 & 44.8 & 1.89 & 50.4 & 27.2 & 3.10 & & \\
\hline $35-7,39-41$ & 323.9 & & & & & & & & & & & 113.66 & \\
\hline $36-1,40-45$ & 324.4 & 1.691 & 1.657 & 1.87 & 1.89 & 49.6 & 48.4 & 1.92 & 49.1 & 26.2 & 3.14 & & \\
\hline $36-2,29-34$ & 325.8 & 1.694 & 1.690 & 1.90 & 1.93 & 47.8 & 46.0 & 1.89 & 49.9 & 27.0 & 3.19 & & \\
\hline $37-1,125$ & 334.7 & & & & & & & & & & & & 3.287 \\
\hline $37-1,133-135$ & 334.8 & & & & & & & & & & & $>113.66$ & \\
\hline $37-2,138-142$ & 334.9 & 1.700 & 1.692 & 2.12 & 1.98 & 34.6 & 43.0 & 1.97 & 50.6 & 26.3 & 3.33 & & \\
\hline $37-4,81-83$ & 337.8 & & & & & & & & & & & 36.24 & \\
\hline $37-5,89-93$ & 340.4 & 1.610 & 1.604 & 1.83 & 1.87 & 51.9 & 49.6 & 1.82 & 55.1 & 31.0 & 2.92 & & \\
\hline $37-5,93-96$ & 340.5 & & & & & & & & & & & 65.89 & \\
\hline $37-6,81-84$ & 341.8 & & & & & & & & & & & 105.42 & \\
\hline $38-1,84-87$ & 543.9 & 1.633 & 1.650 & 1.66 & 1.74 & 62.1 & 57.3 & 1.74 & 60.6 & 35.7 & 2.87 & & \\
\hline $38-1,103-106$ & 344.0 & & & & & & & & & & & 98.83 & \\
\hline $38-6,36-39$ & 350.9 & & & & & & & & & & & 28.00 & \\
\hline $38-6,82-85$ & 351.3 & & & & & & & & & & & 56.0 & \\
\hline $38-7,5-8$ & 352. & 1.662 & 1.639 & 1.85 & 1.88 & 50.7 & 49.0 & 1.82 & 57.0 & 32.0 & 2.98 & & \\
\hline $39-5,49-52$ & 359. & 1.638 & 1.628 & 1.73 & 1.77 & 57.9 & 55.5 & 1.73 & 61.7 & 36.6 & 2.82 & & \\
\hline $40-1,40-43$ & 362.4 & 1.678 & 1.708 & 1.62 & 1.77 & 64.5 & 55.5 & 1.72 & 61.2 & 36.4 & 2.94 & & \\
\hline $40-4,65-68$ & 367.2 & 1.686 & 1.662 & 1.89 & 1.88 & 48.4 & 49.0 & 1.78 & 59.2 & 34.1 & 2.96 & & \\
\hline $40-6,50-53$ & 370. & & & & & & & & & & & 75.77 & \\
\hline $41-1,107-110$ & 372.6 & & & & & & & & & & & 88.95 & \\
\hline $41-3,90-95$ & 375.4 & 1.635 & 1.647 & 1.86 & 1.86 & 50.1 & & 1.77 & 58.2 & 33.7 & 2.92 & & \\
\hline $41-4,28-31$ & 376.3 & & & & & & & & & & & 93.89 & \\
\hline $41-4,36-39$ & 376.4 & 1.669 & 1.671 & 1.94 & 1.96 & 45.4 & 44.2 & 1.89 & 50.0 & 27.1 & 3.16 & & \\
\hline $42-1,12-16$ & 381.1 & 1.623 & 1.663 & 1.77 & 1.86 & 55.5 & 50.1 & 1.76 & 60.0 & 35.0 & 2.93 & & \\
\hline $42-4,72-78$ & 386.3 & 1.685 & 1.689 & 1.79 & 1.76 & 54.3 & 56.1 & 1.71 & 62.0 & 37.1 & 2.89 & & \\
\hline $42-7,10$ & 390.3 & & & & & & & & & & & & 2.966 \\
\hline $42-7,33$ & 390.3 & & & & & & & & & & & & 3.200 \\
\hline $43-1,107-112$ & 391.6 & 1.670 & 1.682 & 1.85 & 1.79 & 50.7 & 54.3 & 1.82 & 55.8 & 31.4 & 3.06 & & \\
\hline $43-2,58-61$ & 392.6 & & & & & & & & & & & 105.42 & \\
\hline $43-4,18-24$ & 395.2 & 1.628 & & & & & & 1.74 & 59.8 & 35.2 & 2.83 & & \\
\hline $43-5,99-103$ & 397.5 & 1.645 & 1.689 & 1.59 & 1.68 & 66.3 & 60.9 & 1.65 & 65.4 & 40.6 & 2.79 & & \\
\hline $44-4,123-128$ & 405.8 & 1.719 & 1.691 & 1.91 & 1.92 & 47.2 & 46.6 & 1.79 & 59.8 & 34.1 & 3.03 & & \\
\hline $44-7,17-20$ & 409.2 & 1.638 & 1.622 & 1.79 & 1.74 & 54.3 & 57.3 & 1.70 & 63.0 & 38.0 & 2.76 & & \\
\hline $45-1,136-140$ & 410.9 & 1.705 & 1.663 & 1.74 & 1.81 & 57.3 & 53.1 & 1.71 & 63.1 & 37.9 & 2.84 & & \\
\hline $45-3,42-48$ & 412.9 & 1.664 & 1.702 & 1.75 & 1.73 & 56.7 & 57.9 & 1.66 & 66.4 & 41.0 & 2.83 & & \\
\hline $47-1,32-36$ & 428.8 & 1.668 & 1.688 & 1.81 & 1.80 & 53.1 & 53.7 & 1.74 & 60.7 & 35.8 & 2.94 & & \\
\hline $47-2,131-135$ & 431.3 & 1.594 & 1.595 & 1.72 & 1.61 & 58.5 & 65.1 & 1.67 & 61.6 & 37.7 & 2.66 & & \\
\hline $48-1,105-109$ & 439.1 & 1.661 & 1.622 & 1.74 & 1.78 & 57.3 & 54.9 & 1.69 & 63.0 & 38.2 & 2.74 & & \\
\hline $48-3,63-67$ & 441.7 & 1.654 & 1.613 & 1.80 & 1.91 & 53.7 & 47.2 & 1.76 & 59.2 & 34.6 & 2.84 & & \\
\hline $48-5,113$ & 445.1 & & & & & & & & & & & & 2.875 \\
\hline $48-6,121-125$ & 446.7 & 1.701 & 1.635 & 1.75 & 1.79 & 56.7 & 54.3 & 1.75 & 57.9 & 34.0 & 2.86 & & \\
\hline $49-1,84-87$ & 448.3 & 1.702 & 1.674 & 1.81 & 1.79 & 53.1 & 54.3 & 1.71 & 61.8 & 37.0 & 2.86 & & \\
\hline $49-4,2-5$ & 452.0 & 1.700 & 1.658 & 1.74 & 1.73 & 57.3 & 57.9 & 1.73 & 59.0 & 35.0 & 2.87 & & \\
\hline $50-1,67-70$ & 457.7 & 1.663 & 1.651 & 1.71 & 1.72 & 59.1 & 58.5 & 1.72 & 58.2 & 34.7 & 2.84 & & \\
\hline
\end{tabular}

Note: Some shear strength measurements exceeded instrumentation limits and are indicated by a greater than ( $>$ ) symbol. These values are not plotted in any figures and the values are considered below failure strength of the material.

${ }^{\mathrm{H}} \mathrm{H}=$ horizontal, $\mathrm{V}=$ vertical. 
sedimentary sections were cored with a 1-in. plastic sampling tube, the cylindrical axis of which is perpendicular to the surface of the split core (presumably parallel to bedding in the hole). Velocity measurements on soft sediment were attempted only in a direction parallel to the mini-cylinder core axis. More consolidated samples were cut into cubes from the split cores in such a way that one pair of faces on the cube are parallel to the core axis and the other pair of cube faces are perpendicular to the core axis. The orientation of the cubic sample to the core axis will be denoted as "perpendicular" and "parallel" (implicitly, to the geologic formation in the hole), respectively, hereafter. Ultrasonic velocity measurements were made through both orientations of the cubic samples.

The accuracy of the velocity measurements was calibrated using three standards provided on the ship. Eleven test measurements were run on each standard: lucite, brass, and aluminum blocks. Errors for each test run were $1.0,0.8$, and $0.2 \%$, respectively. The maximum error in the Hamilton Frame system itself is estimated to be $1.5 \%$. This figure is probably not applicable to samples that do not have completely parallel surfaces or a sufficiently large ratio of length to thickness, as is probably true for most hand-trimmed samples. The accuracy and reproducibility of the velocity measurements is approximately $2 \%$.

\section{Gravimetric Data: Wet-Bulk Density, Porosity, and Water Content}

Gravimetric data, as well as gamma-ray (GRAPE) density measurements and carbonate content, were determined for all the samples tested for sonic velocities. The density data were obtained by weighing water-saturated samples. Porosity and water content were then calculated by weighing these samples after dehydrating at $110^{\circ} \mathrm{C}$ in an oven.

\section{Gamma-Ray Technique (2-minute GRAPE)}

The 2-minute gamma-ray technique (GRAPE) was also used to determine the corrected wet-bulk density of individual consolidated samples. From the corrected wetbulk density, the true wet-bulk density and porosity were calculated (based upon certain assumptions on the grain density of quartz and the corrected grain densities determined from the gravimetric measurements). Also, continuous GRAPE measurements for all of the recovered cores at Site 541 were performed immediately after recovery except for Cores 23 to 37, when the GRAPE machine was inoperative.

\section{Shear Strength}

Shear strength of semiconsolidated sediment in split sections of the cores was measured using a Wykeham Farrance Vane Shear Frame (model 23500, serial 861) and a Lebow Torque Sensor (model 1102-50, serial 1081) supplied by the U.S. Geological Survey. Shear strength measurements were recorded on an analog strip-chart recorder (Soltec model S-4201, serial 60158). Samples (e.g., Section 541-10,CC) were collected from the site of each shear strength measurement for later analyses of water and carbonate content.

\section{Thermal Conductivity}

Thermal conductivity of selected sedimentary cores was measured by using a needle probe (serial no. 27, DSDP). The thermal conductivity $\kappa$ was calculated by the following formula:

Needle Probe (no. 27) $\kappa=\frac{\left(0.8774 \times 10^{-3}\right)\left[\ln \left(t_{2} / t_{1}\right)\right]}{T_{2}-T_{1}(\mathrm{cal} / \mathrm{cm} \cdot \mathrm{s} \cdot \mathrm{deg})}$

where $t$ and $T$ are time and temperature, respectively. Recovered cores were allowed to equilibrate to the ambient room temperature for at least $\mathbf{4 h r}$. (often as long as $12 \mathrm{hr}$.).

\section{PHYSICAL PROPERTIES RESULTS}

All the results of physical property measurements on cores from Site 541 are listed in Tables 3 and 4 and shown diagramatically in Figures 7 to 10.

\section{Sonic Velocities}

On the average, two ultrasonic measurements were made on samples from each core (Table 3). One distinctive observation is that the variation in compressional velocity throughout the entire hole is extremely uniform and quite small (Fig. 7). The slowest velocity, measured near the top of the hole at a sub-bottom depth of $7.5 \mathrm{~m}$, is $1.482 \mathrm{~km} / \mathrm{s}$ (Table 3). The fastest velocity, measured in the lower part of the hole at a sub-bottom depth of $305 \mathrm{~m}$, is $1.727 \mathrm{~km} / \mathrm{s}$. Thus the maximum difference in velocity throughout the drilled section is one $245 \mathrm{~m} / \mathrm{s}$ $(0.245 \mathrm{~km} / \mathrm{s})$ or about $16.5 \%$. As can be seen in Figure 7 , the increase in velocity down the hole is very slight, very gradual, and linear.

To investigate further the rather monotonous increase in velocity with depth for Site 541, the vertical components of the sonic velocities were converted to acoustic impedance (denoted $z$ hereafter), defined as:

$$
z=\rho \cdot V_{\mathrm{p}} \text { or (density } \times \text { vertical velocity) }
$$

Because acoustic impedance varies with both density and velocity and because the velocity increased very gradually down the hole, we hoped to find impedance variation corresponding to density variations. However, as can be seen in Figure 8, the density values of the samples are distributed in a narrow and limited range. Thus the computed impedance values listed in Table 3 and shown on Figure 7 mimic the trend of the sonic velocity and density values. The impedance values increase gradually with depth, except for a slight decrease below a sub-bottom depth of $340 \mathrm{~m}$, which corresponds to a slight decrease in density at the same depth (see section below).

In order to describe the variation in velocity with depth, we calculated mean velocities for given depth increments as well as for the entire hole, as shown in Table 4. As this table shows, the average velocities paral- 


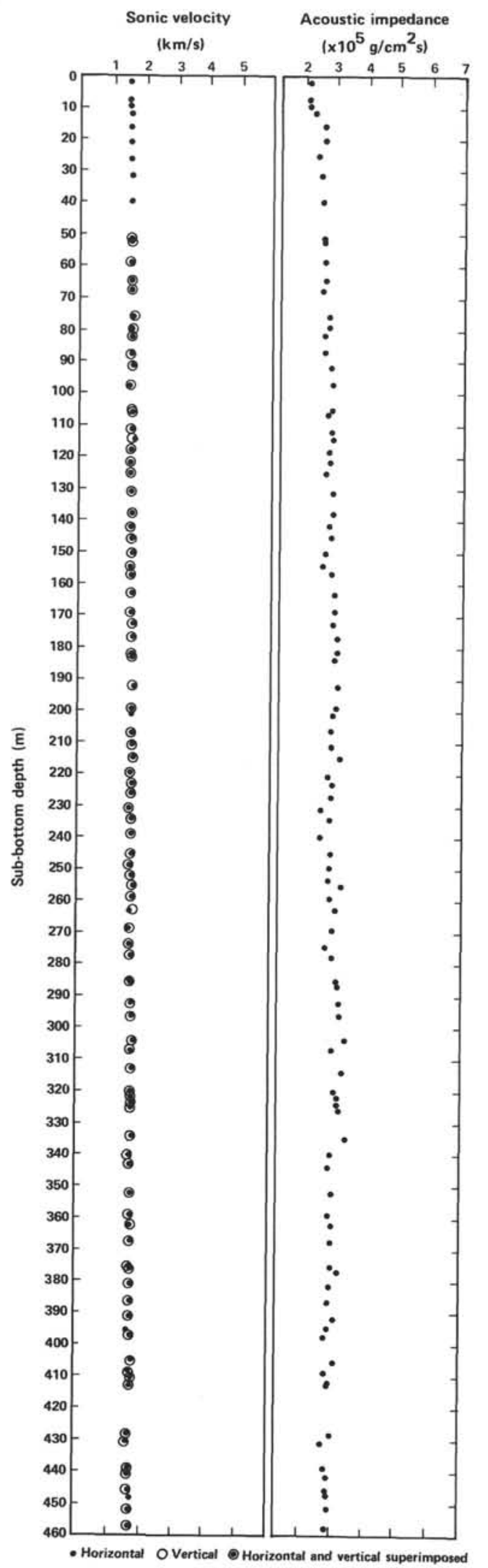

Figure 7. Plot of acoustic impedance and sonic velocity versus depth at Site 541. (Sonic velocities are calculated from recovered core samples and are not corrected to in situ values. Acoustic impedance values are also not corrected to in situ values.) lel and perpendicular to the cores for the entire hole are virtually indistinguishable. This relationship suggests that core material from the site is acoustically isotropic.

In order to test whether samples from Site 541 are indeed acoustically isotropic, we computed relative anisotropy for each core sample from the relationship:

$$
\text { Anisotropy } A_{\mathrm{n}}(\%)=100 \times\left(V_{\|}-V_{\perp}\right) /\left(V_{\|}+V_{\perp}\right)
$$

The results of these calculations are shown in Table 5 . For all 88 computations, the average anisotropy, $\overline{\mathrm{A}}_{\mathrm{n}}$, is $-0.05 \%$ with a standard deviation of $0.94 \%$, which is statistically insignificant. If we exclude the last six calculations for Cores 48, 49, and 50, then the average anisotropy is $-0.14 \%$ with a standard deviation of $0.90 \%$, again a rather insignificant figure. If we now examine the six measurements for Cores 48 to 50, we find the average anisotropy is $+1.15 \%$ with a standard deviation of $0.54 \%$. This last figure of $+1.15 \%$, albeit derived from a small population of 6 , may be significant when correlated with lithologic and seismic reflection data from Site 541.

At a sub-bottom depth of $438 \mathrm{~m}$ at Site 541, the bit encountered a radiolarian-bearing, yellowish brown mudstone of the late early Miocene. These were the oldest beds as well as the only beds containing radiolarians recovered at Site 541. Although these beds do not differ significantly in terms of their velocity profile from the overlying sections, they are definitely anisotropic, unlike the rest of the hole.

To investigate further the acoustic and lithologic changes beginning at Core 48 , we corrected the average velocities measured in the laboratory to in situ velocities. To correct the laboratory velocity values to in situ, we used the approach favored by Boyce (1976). According to Boyce, when sedimentary samples are brought from the subsurface to the ship, both the original in situ overburden pressure $(p)$ and temperature $(T)$ of the sample are changed to those of the laboratory. Using the empirical law given by Boyce (1976), correction factors used for obtaining in situ velocities are as follows:

1) $5 \%$ increase for sediment samples with porosities between $30 \%$ and $60 \%$;

2) $3 \%$ increase for sediment samples with porosities between $20 \%$ and $30 \%$;

3) no increase for porosities below $20 \%$.

The average vertical velocity for Site 541 , corrected for in situ conditions, is $1.693 \mathrm{~km} / \mathrm{s}$ and was used in constructing the synthetic seismic-reflection profile shown in Figure 9. As this figure shows, there is an excellent correlation between a reflector observed on profile A1D across Site 541 (Figure 3) and the predicted lithologic change at a sub-bottom depth of $438 \mathrm{~m}$ (Core 48). Thus, to conclude, the section drilled at Site 541 is acoustically monotonous except for an anisotropic and lithologic boundary at a sub-bottom depth of $438 \mathrm{~m}$ (Core 48), a boundary where the oldest sedimentary section in the hole was recovered and a boundary that appears to correspond to a major reflection event on line A1D across the drilling site. 


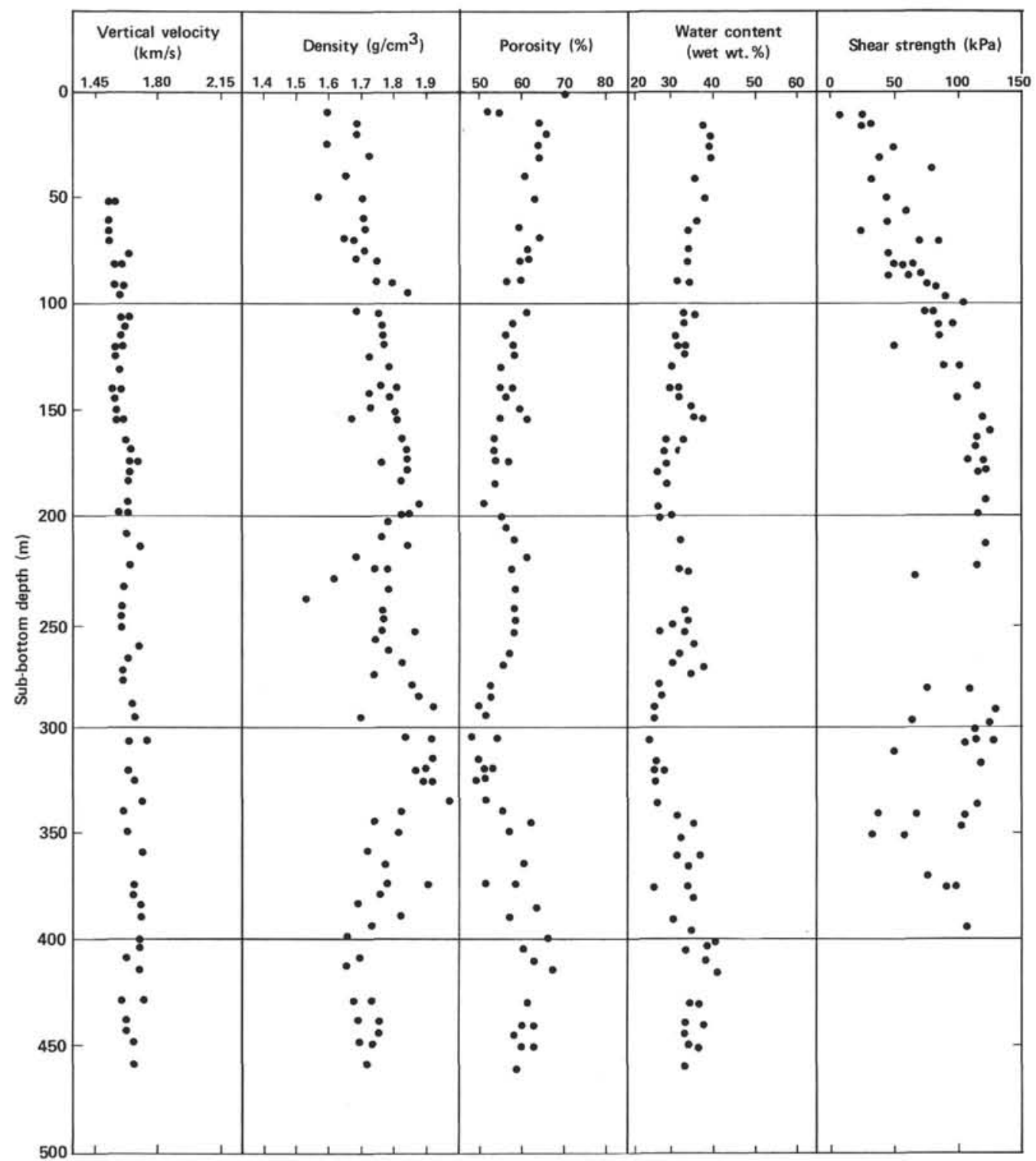

Figure 8. Plot of water content (wet wt. $\%$ ), porosity $(\%)$, density $\left(\mathrm{g} / \mathrm{cm}^{3}\right)$, vertical velocity $(\mathrm{km} / \mathrm{s})$, and shear strength $(\mathrm{kPa})$ values versus depth at Site 541 .

Table 4. Average sonic velocities, Site 541.

\begin{tabular}{cccccccc}
\hline & $\begin{array}{c}\text { Depth } \\
\text { range } \\
\mathrm{m}\end{array}$ & $\begin{array}{c}\bar{V}_{\|} \\
(\mathrm{km} / \mathrm{s})\end{array}$ & $\mathrm{S}$ & $\mathrm{N}$ & $\begin{array}{c}\bar{V}_{\perp}{ }^{\mathrm{a}} \\
(\mathrm{km} / \mathrm{s})\end{array}$ & $\mathrm{S}$ & $\mathrm{N}$ \\
\hline & $0-100$ & 1.527 & 0.040 & 20 & 1.541 & 0.039 & 20 \\
& $100-200$ & 1.597 & 0.031 & 22 & 1.595 & 0.032 & 22 \\
& $200-300$ & 1.611 & 0.037 & 27 & 1.623 & 0.038 & 23 \\
& $300-400$ & 1.661 & 0.029 & 21 & 1.663 & 0.032 & 20 \\
& $300-500$ & 1.672 & 0.035 & 12 & 1.655 & 0.033 & 12 \\
Total & $0-459$ & 1.610 & 0.508 & 102 & 1.612 & 0.056 & 97 \\
\hline
\end{tabular}

Note: $\overline{\boldsymbol{V}}_{\|}=$average velocity presumed parallel to bedding and perpendicular to the core; $\bar{V}_{\perp}=$ average velocity presumed perpendicular to bedding and parallel to the core; $\mathrm{S}=$ standard deviation; and $\mathrm{N}=$ number of samples.

a Includes values of $V_{\perp}$ in the upper $70 \mathrm{~m}$ of semiconsolidated material, where $V_{\|}$is assumed to be equal to $\mathrm{V}_{\perp}$.

\section{Porosity, Density, and Water Content}

Porosity and density data were measured from selected core samples that were also analyzed for their acoustical properties using the Hamilton Frame device. Porosity and density analyses were made using gamma-ray techniques (2-min. GRAPE) and by gravimetric weighing. The difference between both methods is generally less than $5 \%$, which is small enough to allow the use of the gamma-ray technique instead of gravimetric measurements for quick calculations. However, the gammaray method is based upon certain assumptions, and if these prerequisites were not satisfied, we found large deviations from the gravimetric data. The gravimetric results are used exclusively in the figure plots and subsequent calculations such as acoustic impedance.

Plots of water content, porosity, and density are shown in Figure 8. As noted earlier, density increases 
Table 5. Calculated anisotropy values for individual core samples from Hole 541 (see text for derivation).

\begin{tabular}{|c|c|c|c|c|c|}
\hline $\begin{array}{c}\text { Sample } \\
\text { (interval in } \mathrm{cm} \text { ) }\end{array}$ & $\begin{array}{l}\text { Sub-bottom } \\
\text { depth } \\
\text { (m) }\end{array}$ & $\begin{array}{c}\text { Anisotropy } \\
(\%)\end{array}$ & $\begin{array}{c}\text { Sample } \\
\text { (interval in cm) }\end{array}$ & $\begin{array}{l}\text { Sub-bottom } \\
\text { depth } \\
\text { (m) }\end{array}$ & $\begin{array}{c}\text { Anisotropy } \\
(\%)\end{array}$ \\
\hline $7-2,109-112$ & 51 & -0.88 & $28-1,90-93$ & 249 & -0.41 \\
\hline $7-3,53-56$ & 52 & -0.03 & $28-4,34-37$ & 253 & -0.90 \\
\hline $8-1,69-71$ & 59 & -0.66 & $28-5,108-111$ & 255 & -0.77 \\
\hline $8-5,42-46$ & 65 & 0.62 & $29-2,30-33$ & 259 & -0.34 \\
\hline $8-7,49-53$ & 68 & -0.63 & $29-4,110-113$ & 263 & -4.13 \\
\hline $9-6,89-91$ & 76 & -2.90 & $30-2,75-79$ & 269 & -1.38 \\
\hline $10-2,79-82$ & 79 & -1.01 & $30-5,103-107$ & 274 & 0.09 \\
\hline $10-4,50-53$ & 82 & 0.36 & $31-1,130-133$ & 278 & 1.07 \\
\hline $11-1,99-102$ & 88 & -0.15 & $31-6,111-114$ & 285 & -0.40 \\
\hline $11-4,54-57$ & 92 & -0.22 & $32-1,52-55$ & 287 & -0.43 \\
\hline $12-1,118-122$ & 97 & -0.64 & $32-5,34-37$ & 292 & 0.21 \\
\hline $12-7,12-15$ & 105 & 0.16 & $33-1,104-107$ & 297 & -0.30 \\
\hline $13-1,89-92$ & 106 & -2.15 & $33-7,31-34$ & 305 & -0.32 \\
\hline $13-5,41-44$ & 112 & -0.31 & $34-2,87-86$ & 307 & 0.37 \\
\hline $13-7,25-28$ & 115 & 2.00 & $34-6,108-112$ & 314 & -0.06 \\
\hline $14-3,40-43$ & 118 & 0.16 & $35-4,103-106$ & 320 & 0.91 \\
\hline $14-5,70-73$ & 122 & -0.48 & $35-6,33-36$ & 322 & 0.40 \\
\hline $15-1,80-83$ & 125 & 0.06 & $36-1,40-45$ & 324 & 1.02 \\
\hline $15-5,41-44$ & 131 & 0.19 & $36-2,29-34$ & 326 & 0.12 \\
\hline $16-3,58-60$ & 138 & -0.25 & $37-1,138-142$ & 335 & 0.24 \\
\hline $16-6,50-52$ & 142 & 0.54 & $37-5,89-93$ & 340 & 0.19 \\
\hline $17-2,35-38$ & 145 & 0.38 & $38-1,84-87$ & 344 & -0.52 \\
\hline $17-5,85-88$ & 150 & 1.70 & $38-1,5-8$ & 352 & 0.70 \\
\hline $18-1,108-111$ & 154 & 0.87 & $39-5,49-52$ & 359 & 0.31 \\
\hline $18-3,122-126$ & 157 & -0.25 & $40-1,40-43$ & 362 & -0.89 \\
\hline $19-1,89-92$ & 163 & -0.50 & $40-4,65-68$ & 367 & 0.72 \\
\hline $19-5,64-67$ & 169 & -0.66 & $41-3,90-95$ & 375 & -0.37 \\
\hline $20-1,76-79$ & 173 & -0.03 & $41-4,36-39$ & 376 & -0.06 \\
\hline $20-4,39-43$ & 177 & -1.36 & $42-1,12-16$ & 381 & -1.22 \\
\hline $21-1,72-76$ & 182 & -0.59 & $42-4,72-78$ & 386 & -0.12 \\
\hline $21-2,51-54$ & 184 & -0.09 & $43-1,107-112$ & 392 & -0.36 \\
\hline $22-2,21-24$ & 193 & -0.43 & $43-5,99-103$ & 398 & -1.32 \\
\hline $22-6,91-94$ & 199 & -0.89 & $44-4,123-128$ & 406 & 0.82 \\
\hline $23-1,47-50$ & 201 & 0.69 & $44-7,17-20$ & 409 & 0.49 \\
\hline $23-5,52-55$ & 207 & -0.06 & $45-1,136-140$ & 411 & 1.25 \\
\hline $24-1,69-72$ & 211 & -0.12 & $45-3,42-48$ & 413 & -1.13 \\
\hline $24-4,66-69$ & 215 & -0.18 & $47-1,32-36$ & 429 & -0.60 \\
\hline $25-1,101-104$ & 221 & -0.76 & $47-2,131-135$ & 431 & -0.03 \\
\hline $25-3,54-57$ & 223 & 0.37 & $48-1,105-109$ & 439 & 1.19 \\
\hline $25-7,28-31$ & 227 & -0.37 & $48-3,63-67$ & 442 & 1,26 \\
\hline $26-2,78-80$ & 231 & -0.03 & $48-6,121-125$ & 447 & 1.98 \\
\hline $26-4,68-70$ & 234 & 1.28 & $49-1,84-87$ & 448 & 0.83 \\
\hline $27-1,107-110$ & 240 & -0.18 & $49-4,2-5$ & 452 & 1.25 \\
\hline $27-5,60-63$ & 245 & 1.05 & $50-1,67-70$ & 458 & 0.36 \\
\hline
\end{tabular}

gradually with depth until a sub-bottom depth of about $340 \mathrm{~m}$, where the density decreases from $1.97 \mathrm{gm} / \mathrm{cm}^{3}$ to $1.74 \mathrm{gm} / \mathrm{cm}^{3}$ (a $12 \%$ decrease). Below $340 \mathrm{~m}$ sub-bottom the average density is nearly constant, about 1.75 $\mathrm{gm} / \mathrm{cm}^{3}$, to the bottom of the hole.

The porosity and water content of samples from Site 541 decrease rapidly from near the seafloor to a subbottom depth about $15 \mathrm{~m}$, and then the values decrease gradually to a depth near $150 \mathrm{~m}$. At around 150 to $160 \mathrm{~m}$ below the seafloor, the porosity and water content exhibit a sharp increase and then sudden decrease, which may correspond to the Pliocene/Miocene boundary encountered in the hole at this depth. Below $160 \mathrm{~m}$ to the bottom of the hole, both the porosity and water content exhibit a cyclic increase and decrease in values over two cycles with a wave length of 120 to $140 \mathrm{~m}$. This repetitious sinusoidal fluctuation in the two values may correspond to the stratigraphic repetition of Pliocene and Miocene sedimentary sequences across a major thrust fault near 276 meters sub-bottom (see the Lithology section, this chapter).

\section{Shear Strength}

Shear strength was measured for all but the lower few cores; the values are listed in Table 3 and are shown in Figures 4 and 8 . Shear-strength measurements increase rapidly from the seafloor to a sub-bottom depth of

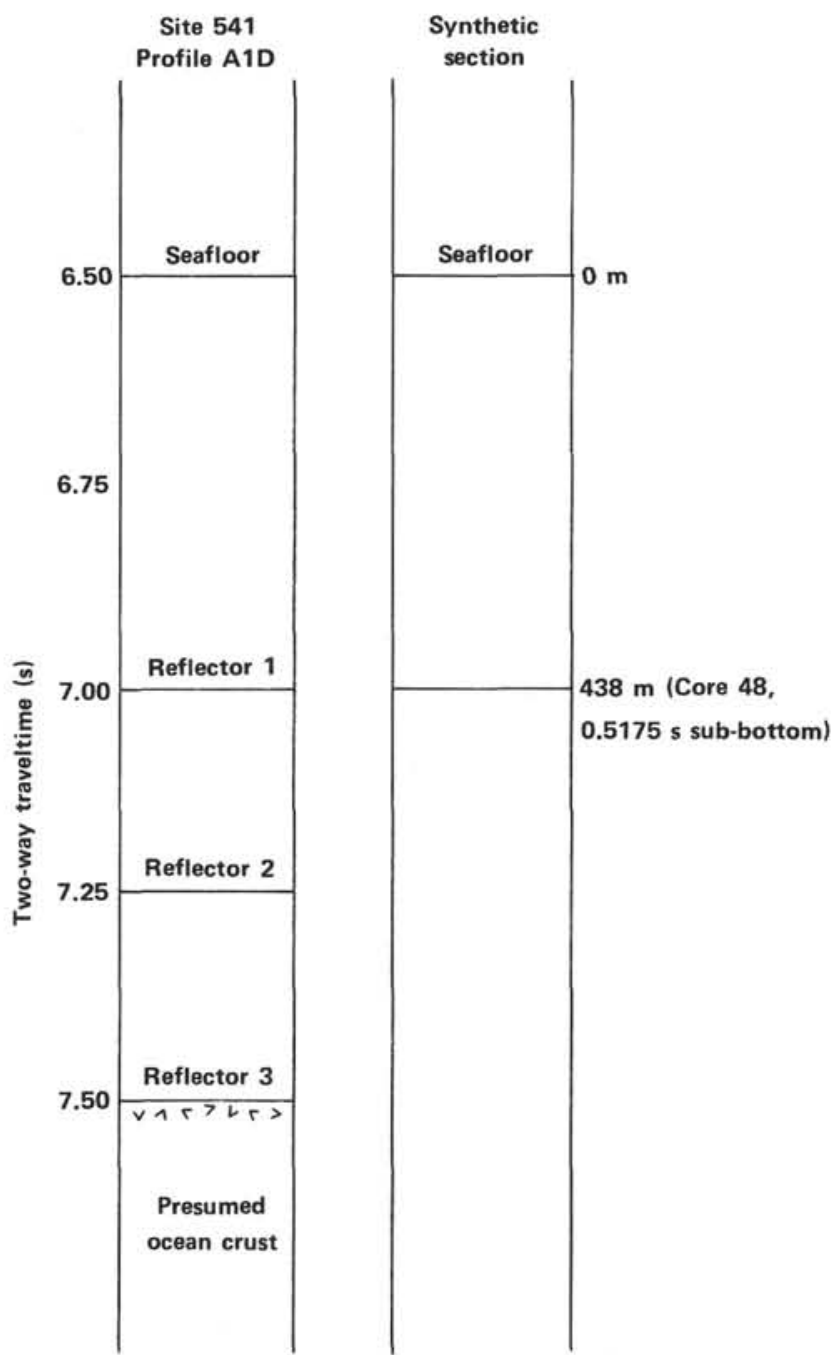

Figure 9. Interpretive seismic stratigraphy of Site 541 derived from seismic reflection profile A1D across the site compared to a synthetic profile based on physical properties of core samples from the site. (See text for explanation.)

about $140 \mathrm{~m}$, although there is a great deal of scatter in the data from the upper cores (probably due to drilling disturbance). From 140 to $320 \mathrm{~m}$ shear-strength values are constant or decrease slightly. Below $280 \mathrm{~m}$ and a major reverse fault, the values are scattered but generally low. Note that the sudden change in shear-strength behavior occurs at a sub-bottom depth of $140 \mathrm{~m}$, close to the boundary between the Pliocene and Miocene sedimentary sections. The fairly uniform values of shear strength from 140 to $320 \mathrm{~m}$ suggest that the cored strata in this interval have reached a maximum strength, perhaps due to consolidation from either overburden pressure or tectonic deformation or both.

\section{Thermal Conductivity}

A total of 14 conductivity measurements were made throughout the hole at Site 541. These values were used in conjunction with temperature readings measured by probe and logging techniques to calculate heat flow (see the Temperature Measurements section, this chapter; 
and Davis et al., this volume). The conductivity of the semiconsolidated sedimentary strata with relatively high porosity (i.e., high water content) is low, around 2 to 3 $\times 10^{-3} \mathrm{cal} / \mathrm{cm} \cdot \mathrm{s} \cdot \operatorname{deg}$. Near the Pleistocene/Pliocene boundary, conductivity values increase to a maximum reading of $3.924 \times 10^{-3} \mathrm{cal} / \mathrm{cm} \cdot \mathrm{s} \cdot \mathrm{deg}$. Values below this depth decrease slightly and average around $3.0 \times$ $10^{-3} \mathrm{cal} / \mathrm{cm} \cdot \mathrm{s} \cdot \mathrm{deg}$ to the bottom of the hole. One interesting low value of $2.100 \times 10^{-3} \mathrm{cal} / \mathrm{cm} \cdot \mathrm{s} \cdot \mathrm{deg} \mathrm{oc}-$ curs about $307.5 \mathrm{~m}$ sub-bottom, just below a major thrust contact in the drilled sequence.

\section{Continuous GRAPE (Gamma-Ray Measurement)}

All cores except 32 to 37 were logged through GRAPE, and an uncorrected density data file was compiled on board ship. Before quantitative estimates of core density can be made, these data must be corrected for core diameter variation, lithology changes, material surrounding the core, and core alignment. Also, core disturbance, which is considerable in the upper muddy cores, may strongly influence GRAPE density.

Immediate qualitative comparison of core density may be made from the raw GRAPE density logs in semiconsolidated material. For cores of equal diameter, direct comparisons of varying lithologies can be made and density difference approximated. Breaks in the cores can be qualitatively eliminated and density-lithology comparisons made by comparing raw GRAPE logs with archive section photographs. Unfortunately, significant changes in lithology were not apparent either during vis- ual inspection of the cores or in the density values from Site 541.

\section{Some Related Findings}

Figure 10 is a plot of porosity versus density measurements from cores taken at Site 541. Except for a few scattered points, most of the data plot as a linear function. Also shown is the empirically derived equation from DSDP relating density and porosity:

$$
\rho_{\mathrm{b}}=2.70-1.675 \phi(\mathrm{DSDP})
$$

where $\rho_{\mathrm{b}}=$ wet-bulk density of a sample and $\phi=$ porosity of a sample. As can be seen from the plot, the agreement is quite good between the observed data and the empirically derived relation. The implication, albeit speculative, is that the entire column of drilled strata is composed of mineralogically fairly uniform material without substantial change down the hole.

\section{Discussion}

The rather uniform nature of the physical properties measured at Site 541, including sonic velocities, densities, porosities, acoustic impedances, and so on, is rather surprising. Although lithologic and fossil data demonstrate that the site is underlain by repetitive stratigraphic sections in probable thrust contacts, the physical properties are remarkably uniform. If the hole at Site 541 did indeed penetrate an active convergence zone flanking the Lesser Antilles arc, then we are puzzled by

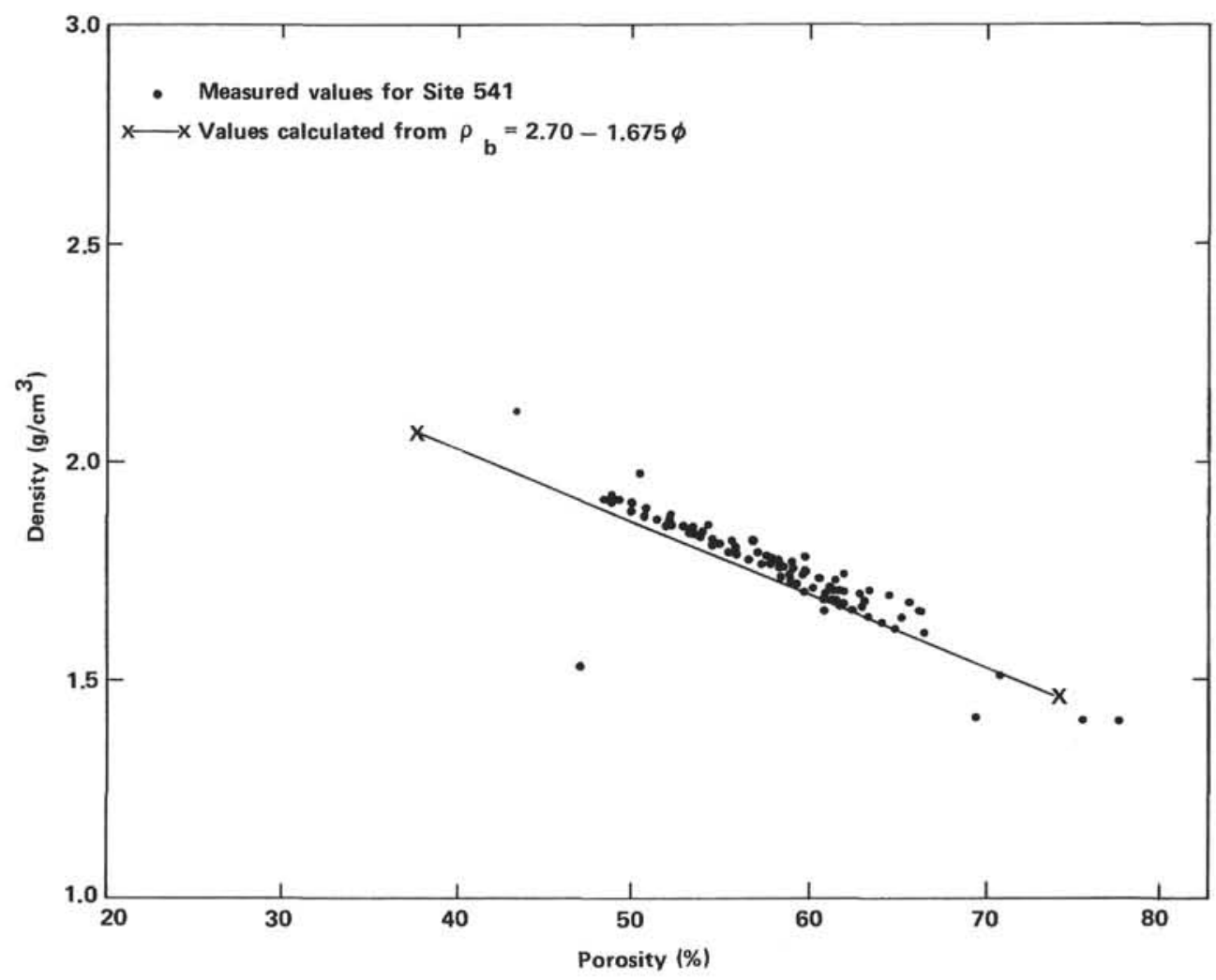

Figure 10. Plot of density versus porosity for core samples from Site 541. (See text for discussion.) 
the lack of significant breaks in the physical properties of the cored material.

Perhaps the explanation for the uniform behavior of strata in what is thought to be a highly tectonized subduction zone lies in the in situ, interstitial pore fluids within the subduction complex. These fluids may be absorbing the tectonic "shock" of overburden pressure as well as lateral motion from the underthrusting Atlantic Plate. Mobilized, high-pressurized pore water may allow the sedimentary section to deform very uniformly with depth in the convergence zone, giving rise to the uniform physical properties measured in the recovered cores. Moreover, actual in situ variations may exist in the form of fracture porosity that would be impossible to measure on small shipboard samples.

\section{PALEOMAGNETICS}

Paleomagnetic sampling for Site 541 was carried out with two objectives: to help determine age by polarity stratigraphy; and to infer in situ structure with estimates of bed strikes. To avoid problems with drilling disturbance or rotation due to undetected tectonic tilting, samples were only taken at visible beds. Drilling and tectonic disturbance led to no samples being taken from the intervals 0 to $59 \mathrm{~m}, 209$ to $289 \mathrm{~m}$, and $341-376 \mathrm{~m}$. Generally the sample interval was 1 to $2 \mathrm{~m}$, with occasional gaps of several meters due to lack of recovery or the disturbed nature of the core. Because of the high sedimentation rate, this rather sparse sample interval was adequate for polarity stratigraphy over most of the hole.

In the less consolidated parts of the core, samples were taken by pressing at least one plastic cube $(2 \times 2$ $\times 1.5-\mathrm{cm}$ ) into each section. These cubes, scribed with arrows pointing upcore, were pried from the rest of the core. In the more consolidating regions, an upcore arrow was scribed directly on the core, and a sample of measurable size was sawn or drilled. The samples were measured on the shipboard Digico fluxgate spinner magnetometer, with alternating field demagnetization studies carried out using the Schoenstedt alternating-field demagnetizer. For some of the specimens, follow-up studies were done on the SCT (Superconducting Technology) two-axis cryogenic magnetometer with built-in alternating-field demagnetizer at Stanford University. For the shipboard measurements, the most straightforward procedure was to imagine an arrow on the top (upcore side) of each specimen pointing toward the upcore arrow scribed on the side of the sample. The hypothetical arrow corresponds to the fiducial line referred to in the Digico manual and allows the samples to be measured without using the time-consuming field or bedding corrections. The Digico convention defines the coordinate system for relative declinations: the direction normal to and away from the cut surface of the core is $0^{\circ}$, increasing clockwise looking downcore. In this coordinate system, the working half of the core is the "south" half. This same coordinate system was used to record strikes and dips of bedding for structural analysis. At each measurable bed, the core was sliced to give apparent dips in two different planes, defining the bedding plane.
The strike of the bed was taken to be the line in the bedding plane normal to the axis of the core. By convention, the strikes recorded are $90^{\circ}$ counterclockwise from the down-dip direction. The magnetization directions are corrected for bedding by rotating the direction about the strike line by the amount of the dip.

Figure 11 shows the stable inclinations for the upper $210 \mathrm{~m}$; refer to Wilson (this volume) for a complete presentation of the data. Site 541 latitude is $15^{\circ}$, which should be valid for the entire Neogene. This latitude predicts a di-pole inclination of $28^{\circ}$, which is far enough from horizontal for polarity interpretation, but shallow enough that some horizontal magnetizations should be expected from normal secular variation. Based on this information, a sample with a stable inclination greater than $+10^{\circ}$ was judged to be normal, and one with less than $-10^{\circ}$, reversed.

The interval from 59 to 200 m (Cores 8-22) worked quite well for polarity stratigraphy (see Wilson, this volume; and Fig. 6). The first sample $(59.4 \mathrm{~m})$ is normal, corresponding to either the oldest Brunhes $(0.7 \mathrm{Ma})$ or the Jaramillo event (0.91-0.97 Ma; ages are from Ness et al., 1980). Other recognizable markers are at 88 to $90 \mathrm{~m}$ (Core 11, Sections 2 and 3)-the Olduvai event (1.66-1.87 Ma); the Matuyama/Gauss transition (2.47 Ma) at $120.5 \mathrm{~m}$ (Core 14, Section 4); the Gauss/Gilbert

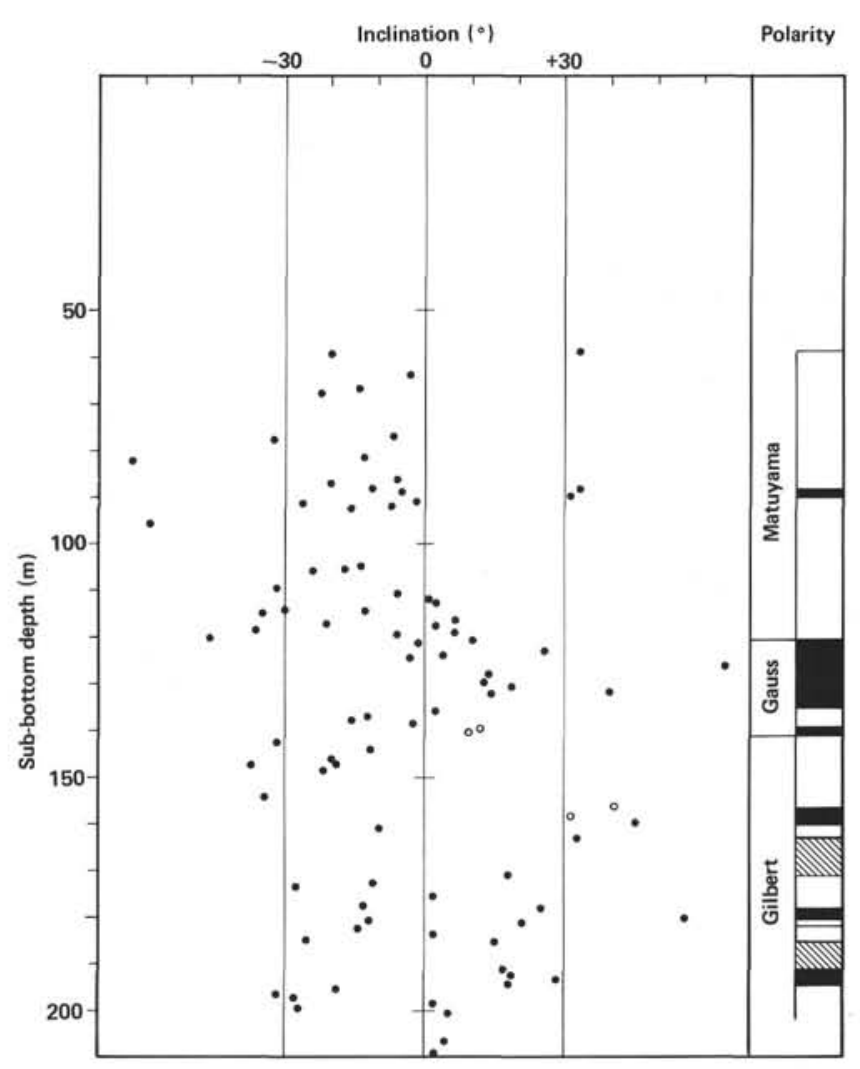

Figure 11. Stable magnetic inclination versus sub-bottom depth, and polarity interpretation. (Black areas indicate normal polarity; white areas show reversed polarity; cross-hatching shows polarity is uncertain or data are missing. Solid vertical lines at $+30^{\circ}$ and $-30^{\circ}$ give possible range of secular variation. Open circles represent data judged to be less reliable than that represented by filled circles.) 
transition (3.40 Ma) at $\sim 141 \mathrm{~m}$ (Core 16, Section 6); and the first normal event in the Gilbert epoch (3.86 Ma) at $156 \mathrm{~m}$ (Core 18, Section 3). If there is a fault at the base of Core 19, the polarity information would indicate about $20 \mathrm{~m}$ of repeated section, with the first normal event in the Gilbert occurring again at $178 \mathrm{~m}$ (Core 20 , Section 5). This correlation is consistent with the two thick ash beds in Core 18 (541-18-1, $140 \mathrm{~cm}$ and $541-18-2,135 \mathrm{~cm}$ ) being the equivalent to the two thick beds in Core 20 (541-20-1, $119 \mathrm{~cm}$ and $541-20-3,15 \mathrm{~cm})$. The polarity transition at $195 \mathrm{~m}$ (Core 22, Section 3) probably corresponds to the last normal event in the Gilbert (4.79 Ma).

The samples from 289 to $340 \mathrm{~m}$ (Cores 32-37) have a high percentage of horizontally magnetized samples, and our few confident polarity determinations are too far apart for polarity stratigraphy. The samples from 382 to $419 \mathrm{~m}$ (Cores $42-44$ ) at first looked promising. Fourteen of fifteen samples have inclinations between 21 and 38 (without tectonic correction), and all of these samples have very high intensities and show exceptional directional stability. However, applying the tectonic correction to the two samples from the overturned section in Core 43, Section 5 resulted in nearly horizontal magnetizations, strongly suggesting a postdeformational magnetization. This interpretation is supported by the failure to observe similar properties of intensity or stability in any samples that might be the same age at Site 543 . The most likely candidate for resetting the magnetization is thermal or chemical changes associated with the warm water observed at the bottom of the hole.

The interpretation of in situ structure provided interesting results. Of the samples collected at dipping beds, twelve have very stable direction, and eight of these have unambiguous polarity. For the samples with clear polarity, true north was assumed to be the declination direction for normal samples, and declination minus $180^{\circ}$ for reversed rocks. The apparent in situ strikes and downdip directions in Table 6 and Figure 12 are relative to this north. For any one sample, the uncertainty in this technique is estimated to be about $40^{\circ}$. The eight samples

Table 6. Structural interpretation based on paleomagnetic data for Hole 541 .

\begin{tabular}{|c|c|c|c|c|c|c|c|}
\hline \multirow{2}{*}{$\begin{array}{c}\text { Sample } \\
\text { (core-section, } \\
\text { cm level) }\end{array}$} & \multicolumn{2}{|c|}{$\begin{array}{l}\text { Bedding } \\
\text { (relative } \\
\text { to core) }\end{array}$} & \multicolumn{3}{|c|}{$\begin{array}{l}\text { Magnetization } \\
\text { (corrected) }\end{array}$} & \multicolumn{2}{|c|}{$\begin{array}{l}\text { Apparent } \\
\text { in situ }\end{array}$} \\
\hline & Strike & Dip & Incl. & Decl. & Polarity ${ }^{a}$ & Strike & $\begin{array}{l}\text { Down-dip } \\
\text { direction }\end{array}$ \\
\hline $18-1,39$ & $300^{\circ}$ & $20^{\circ}$ & $-17^{\circ}$ & $36^{\circ}$ & $\mathbf{R}$ & $84^{\circ}$ & $\mathrm{S}$ \\
\hline $18-5,133$ & $0^{\circ}$ & $20^{\circ}$ & $45^{\circ}$ & $162^{\circ}$ & $\mathrm{N}$ & $198^{\circ}$ & WNW \\
\hline $19-1,77$ & $130^{\circ}$ & $40^{\circ}$ & $32^{\circ}$ & $348^{\circ}$ & $\mathrm{N}$ & $142^{\circ}$ & sw \\
\hline $19-6,110$ & $0^{\circ}$ & $10^{\circ}$ & $18^{\circ}$ & $210^{\circ}$ & $\mathrm{N}$ & $150^{\circ}$ & SW \\
\hline $22-1,64$ & $150^{\circ}$ & $25^{\circ}$ & $17^{\circ}$ & $320^{\circ}$ & $\mathrm{N}$ & $190^{\circ}$ & W \\
\hline $32-3,29$ & $210^{\circ}$ & $45^{\circ}$ & $-30^{\circ}$ & $315^{\circ}$ & $\mathbf{R}$ & $75^{\circ}$ & SSE \\
\hline $37-3,81$ & $330^{\circ}$ & $25^{\circ}$ & $-37^{\circ}$ & $69^{\circ}$ & $\mathbf{R}$ & $81^{\circ}$ & S \\
\hline $37-5,78$ & $0^{\circ}$ & $15^{\circ}$ & $21^{\circ}$ & $188^{\circ}$ & $\mathrm{N}$ & $172^{\circ}$ & W \\
\hline \multicolumn{6}{|c|}{ Polarity ambiguous } & \multicolumn{2}{|c|}{ Strike $\left(0-180^{\circ}\right)$} \\
\hline $23-1,78$ & $310^{\circ}$ & $15^{\circ}$ & $5^{\circ}$ & $46^{\circ}$ & & $84^{\circ}$ & \\
\hline $23-5,78$ & $150^{\circ}$ & $40^{\circ}$ & $4^{\circ}$ & $317^{\circ}$ & & $13^{\circ}$ & \\
\hline $33-6,75$ & $50^{\circ}$ & $45^{\circ}$ & $-4^{\circ}$ & $157^{\circ}$ & & $13^{\circ}$ & \\
\hline $34-1,32$ & $60^{\circ}$ & $30^{\circ}$ & $-6^{\circ}$ & $76^{\circ}$ & & $164^{\circ}$ & \\
\hline
\end{tabular}

${ }^{a} \mathrm{R}=$ reversed, $\mathrm{N}=$ normal.

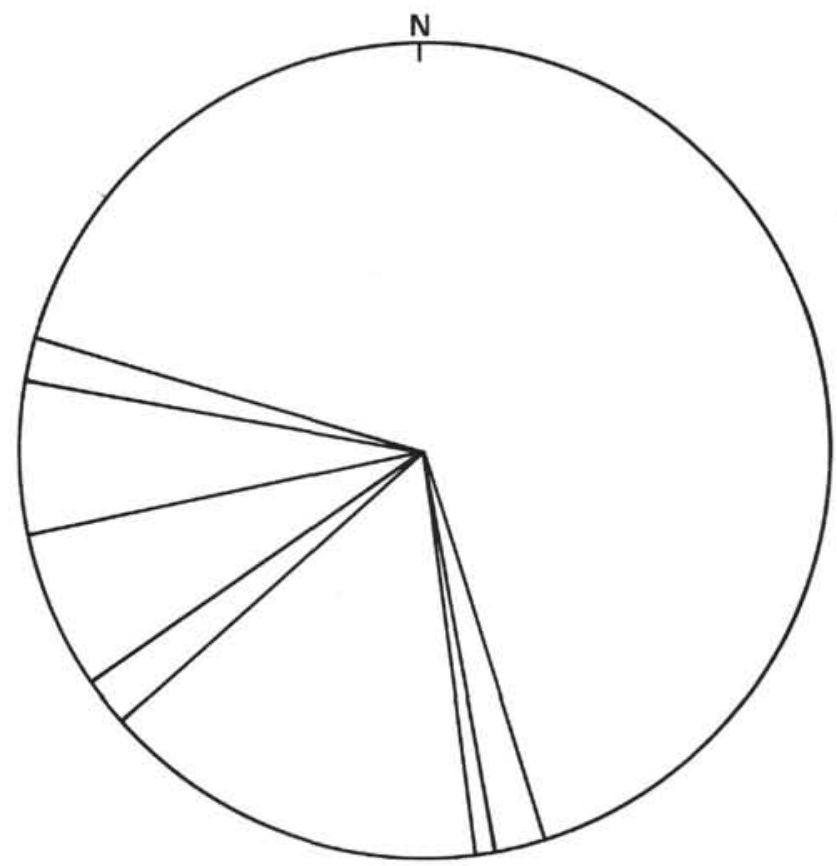

Figure 12. Projected down-dip directions for dipping beds (from Table 6).

with clear polarity scatter about dip directions to the southwest, and the samples with ambiguous polarity are not inconsistent with this. The best interpretation of these data seems to be that the regions of horizontal bedding are separated by bands of monoclinal folding.

\section{TEMPERATURE MEASUREMENTS}

Four temperature measurements were made at Site 541. Two were made in the mud at the bottom of the hole during pauses in the drilling process using the Tokyo T-probe (e.g., Uyeda and Horai, 1982), and two consisted of short excursions of the Gearhart-Owen logging tool past the end of the pipe. The high temperatures measured (roughly $15^{\circ} \mathrm{C}$ at less than $170 \mathrm{~m}$ subbottom) are consistent with rapid upward migration of warm water. For additional details, see Davis et al. (this volume).

\section{SEISMIC STRATIGRAPHY}

As described by Ngokwey et al. (this volume), Site 541 is near the intersection of lines A1D and A1E and the sequence recorded on the seismic reflection records consists of two seismic sequences:

1) $500 \mathrm{~m} / \mathrm{s}$ of acoustically discontinuously reflective character without any coherent reflectors;

2) $500 \mathrm{~m} / \mathrm{s}$ of an acoustically layered sequence resting on the deepest reflector (Reflector 3) that is presumed to be oceanic crust.

These two units are separated by a prominent reflector (Reflector 1), which can be followed in Figure 3 from beneath the Atlantic abyssal plain to the west for some $20 \mathrm{~km}$ beneath the eastern flank of the Barbados Ridge.

From 0 to $276 \mathrm{~m}$ (sub-bottom) the well-layered Pleistocene-Pliocene-upper Miocene sequence does not exhibit any major sharp lithologic boundaries that would 
yield impedance contrasts and resultant seismic reflections. The poor reflectivity of this section is due to the lack of significant changes in the physical properties.

At $276 \mathrm{~m}$ a sharp fault contact was penetrated that separates upper Miocene clays (above) from nannofossil-foraminifer oozes of the lower upper Pliocene (below). This tectonic-stratigraphic inversion is not observed in processed seismic reflection records. The lack of a reflection event at this boundary is probably due to the fact that we found no significant contrasts in velocity or density in the recovered cores from this depth. However, even though reverse faults were observed in Core 30 (near and on the contact itself), the fault discontinuity could be parallel to regional bedding, that is, relatively flat, and not appear as a significant reflector.

From $276 \mathrm{~m}$ to the total depth $(459 \mathrm{~m})$ drilled, the lithological changes are again very gradual; shearing, development of scaly foliation, and brecciation do not correspond to any major change in physical properties of the cores. From velocity calculations (Fig. 7), Reflector 1 , which seismically defines the bottom of the discontinuously reflective sequence, should coincide with the deformation zone at the base of the hole. Sheared yellowish brown radiolarian oozes encountered in this deformation zone (between 438 and $459 \mathrm{~m}$ ) may correspond to Reflector 1 and hence to the top of the underthrust sedimentary section. Reflector 1 also corresponds to the anisotropic fabric in the lowermost cores of Site 541 (see Physical Properties section, this chapter).

\section{SUMMARY AND CONCLUSIONS}

At Site 541 we cored $459 \mathrm{~m}$ and recovered seven lithologic units ranging in age from Quaternary to early Miocene. A major reverse fault occurs at $276 \mathrm{~m}$, as documented by repetition of units. Smaller-scale repetitions occur at 75 to $80 \mathrm{~m}, 172 \mathrm{~m}$, and $263 \mathrm{~m}$. Repetitions at $172 \mathrm{~m}, 263 \mathrm{~m}$, and $276 \mathrm{~m}$ are associated with stratal disruption and/or significant displacements, hence are probably of tectonic origin. The small $(\sim 6 \mathrm{~m})$ displacement and soft consistency of the sediments at 75 to $80 \mathrm{~m}$ possibly suggests slump origin of this repetition. A zone of stratal disruption at the base of the hole suggests proximity to a major fault.

Unit 1, of the Quaternary (Cores 1-8; 0-65 m), consists of nannofossil mud with common ash layers, whereas Unit 2 (Quaternary-lower Pliocene; Cores 9-15; 65-135 $\mathrm{m}$ ) is composed of marly nannofossil ooze and marly foraminiferal ooze with rare ash layers. Unit 3 (Cores $16-25$, Section 3, $50 \mathrm{~cm}$ ); 135-215 m; lower Plioceneupper Miocene), composed of nannofossil mud with ash layers, overlies mud of Unit 4 (Core 25, Section $3,50 \mathrm{~cm}$ to Core 30,Section 6, 215-276 m; upper Miocene), which in turn is faulted against the ashy nannofossil mud of Unit 5 (Core 30, Section 6-Core 37; 276-340 m; upper Pliocene-upper Miocene). Unit 6 (Cores 37-47, Section 2, $50 \mathrm{~cm} ; 340-340 \mathrm{~m}$ ), upper Miocene mudstone, is succeeded downsection by lower Miocene radiolarian mud of Unit 7 (Core 47, Section 2, $50 \mathrm{~cm}$ Core $50 ; 430-459 \mathrm{~m}$ ). Lithologic Units 1 to 4 make up Tectonic Unit A, which overlies Tectonic Unit B (Lithologic Units 5-7) along the major reverse fault at $276 \mathrm{~m}$.
Overall, the deposits cored at Site 541 accumulated in a hemipelagic to pelagic setting at a modest sedimentation rate (see the Accumulation Rates chapter, Wright, this volume), interrupted only by the occasional influx of ash beds and the downslope transport of foraminiferrich turbidites. The clay mineralogy, as determined by $\mathrm{X}$-ray diffraction, indicates mixed volcanic and continental terrigenous sources. The lack of terrigenous turbidites suggests that the section at Site 541 accumulated on a high, possibly the Tiburon Rise. Each Tectonic Unit A and B at Site 541 exhibits a downsection transition from a paleoenvironment at or near the lysocline in the Pliocene to one respectively at or below the CCD in the late Miocene. Time correlative rocks in Unit A accumulated in slightly shallower water than those in Unit B. Temporal variations in the CCD recorded in both units may principally stem from its Miocene shallowing (Berger, 1977), though independent vertical tectonic motions cannot be discounted.

The ash beds in cores from Site 541 provide an historical record of arc volcanism and a precise correlation tool. The temporal frequency of ash beds suggests a climax in eruptive activity in the early Pliocene, followed by a lull in the late Pliocene, culminating with a renewed burst of activity in the Quaternary. The repetition of a distinctive ash-bed sequence from Cores 18, 20, and 34 supports reverse faulting at 172 and 263 to $276 \mathrm{~m}$.

Small-scale structural fabrics occur at both the base of the hole and in association with the documented reverse faults at 263 and $276 \mathrm{~m}$. Inclined beds occur below $125 \mathrm{~m}$ with true dips of up to $45^{\circ}$. The stratal disruption and scaly fabrics characteristic of mudstones above the major reverse fault contrast with the general lack of pervasive fabrics in subjacent nannofossil mud. Fracturing, intense scaly foliation, and stratal disruption characterize cores that locally resemble fault gouge within $100 \mathrm{~m}$ of the base of Hole 451. This concentrated deformation zone may reflect proximity to a décollement separating offscraped and subducted rocks. High concentrations of smectite distinguish both this basal shear zone and the beds near the reverse fault at $172 \mathrm{~m}$, and a deformed zone above the major reverse fault at $276 \mathrm{~m}$.

Seismic reflection profiles through Site 541 reveal a discontinuously reflective unit overlying an acoustically layered sequence. Shipboard velocity measurements suggest penetration just through the discontinuously reflective unit. The sheared radiolarian mudstone below 450 $\mathrm{m}$ at Site 541 may correspond to a prominent reflector at the top of the acoustically layered sequence. Velocitydensity data reveal no impedance contrasts across the faults at 172 and $276 \mathrm{~m}$.

Extremely low levels of hydrocarbon gases (parts per billion) occur in cores from Site 541. Most samples show a full range of $C_{2}$ to $C_{6}$ hydrocarbons and $C_{1}: C_{2}$ ratios varying from 10 to $20: 1$, suggesting in situ thermogenic generation of the hydrocarbons. The rate of increase of $\mathrm{C}_{2}$ to $\mathrm{C}_{6}$ with depth suggests a moderate geothermal gradient. Similarly heat probe and downhole temperature logs indicate anomalously high temperatures at shallow depths.

Penetration of biostratigraphically defined reverse faults in a modern subduction zone is the most significant 
result of drilling at this site. Although the exact origin of this imbricated sequence remains in doubt, the basal transition to radiolarian mudstone favors oceanic origin and hence offscraping. Faulting must postdate the early late Pliocene, the age of the youngest rocks of the lower plate. The lack of a documented middle Miocene section at the base of the hole could be due to structural attenuation in the basal shear zone or a hiatus or a condensed section.

\section{REFERENCES}

Bé, A. W. H., 1980. Gametogenic calcification in a spinose planktonic foraminifer, Globigerinoides sacculifer (Brady). Mar. Micropaleontol., 5:283-310.

Berger, W. H., 1968. Planktonic foraminifera: selective solution and paleoclimatic interpretation. Deep-Sea Res., 15:31-43.

1970. Planktonic foraminifera: selective solution and the lysocline. Mar. Geol., 8:111-138.

1977. Carbon dioxide excursion and the deep-sea record: aspects of the problem. In Anderson, N. R., and Malahoff, A. (Eds.), The Fate of Fossil Fuel $\mathrm{CO}_{2}$ in the Oceans: New York (Plenum Press), pp. 505-542.

1979. Preservation of foraminifera. In Foraminiferal Ecology and Paleoecology, Soc. Econ. Paleontol. Mineral. Short Course, 6:105-155.

Berggren, W. A., 1973. The Pliocene time scale: calibration of planktonic foraminiferal and calcareous nannoplankton zones. Nature, 243:391-397.

Blow, W. H., 1969. Late middle Eocene to recent planktonic biotratigraphy. In Bronnimann, P., and Renz, H. H. (Eds.), Proc. First Int. Conf. Planktonic Microfossils, Geneva, 1967, 1:199-422.

Boyce, R. E., 1976. Definitions and laboratory techniques of compressional sound velocity parameters and wet-water content, wet bulk density and porosity parameters by gravimetric and gammaray attenuation techniques. In Schlanger, S., Jackson, E. D., et al., Init. Repts. DSDP, 33: Washington (U.S. Govt. Printing Office), 931-957.

Bukry, D., and Okada, H., 1980. Supplementary modification and introduction of code numbers to the low-latitude Coccolith biostratigraphic zonation. Mar. Micropaleontol. 5:321-325.

Carey, S. N., and Sigurdsson, H., 1980. The Roseau ash: deep-sea tephra deposits from a major eruption on Dominica, Lesser Antilles arc, J. Volcanol. Geotherm. Res., 7:67-86.
Carroll, D., 1970. Clay minerals: a guide to their X-ray identification. Geol. Soc. Am. Spec. Pap. 126.

Cowan, D. S., 1982. Origin of "vein structure" in slope sediments of the inner slope of the Middle America Trench off Guatemala. In Aubouin, J., von Huene, R., et al., Init. Repts. DSDP, 67: Washington (U.S. Govt. Printing Office), 645-650.

Ekdale, A. A., 1974. Geologic history of the abyssal benthos: evidence from trace fossils in Deep Sea Drilling Project cores (Ph.D. dissert.). Rice University, Houston, Texas.

Gartner, S., 1977. Calcareous nannofossil biostratigraphy and revised zonation of the Pleistocene. Mar. Micropaleontol., 2:1-25.

Gartner, S., and Bukry, D., 1975. Morphology and phylogeny of the Coccolithophycean family, Ceratolithacere. J. Res. U.S. Geol. Surv., 3:451-469.

Lundberg, N., and Moore, J. C., 1982. Structural features of the Middle America trench slope off southern Mexico, Deep Sea Drilling Project Leg 66. In Watkins, J. S., Moore, J. C., et al., Init. Repts. DSDP, 66: Washington (U.S. Govt. Printing Office), 793-814.

Ness, G., Levi, S., and Couch, R., 1980. Marine magnetic anomaly time scales for the Cenozoic and Late Cretaceous: a precis, critique, and synthesis. Rev. Geophys. Space Phys., 18:753-770.

Parker, F. L., and Berger, W. H., 1971. Faunal and solution patterns of planktonic foraminifera in surface sediments of the South-Pacific. Deep-Sea Res., 18:73-107.

Riedel, W. R., and Sanfilippo, A., 1978. Stratigraphy and evolution of tropical Cenozoic radiolarians. Micropaleontology, 23:61-69.

Sanfilippo, A., and Riedel, W. R., in press. Revision of the radiolarian genera Theocotyle, Theocotylissa, and Thyrsocyrtis. Micropaleontology.

Schnitker, D., 1979. Cenozoic deep water benthic foraminifers, Bay of Biscay. In Montadert, L., Roberts, D. G., et al., Init. Repts. DSDP, 48: Washington (U.S. Govt. Printing Office), 377-414.

Sparks, R. S. J., Sigurdsson, H., and Garey, S. N., 1980. The entrance of pyroclastic flows into the sea, I. Oceanographic and geologic evidence from Dominica, Lesser Antilles. J. Volcanol. Geotherm. Res., 7:87-96.

Thunell, R. C., and Honjo, S., 1981. Calcite dissolution and the modification of planktonic foraminiferal assemblages. Mar. Micropaleontol., 6:169-182.

Uyeda, S., and Horai, K., 1982. Heat flow measurements on Deep Sea Drilling Project Leg 60. In Hussong, D. M., Uyeda, S., et al., Init. Repts. DSDP, 60: Washington (U.S. Govt. Printing Office), 789-800. 


\begin{tabular}{|l|l|l|l|l|l|l|l|l|}
\hline SITE & 541 \\
\hline
\end{tabular}

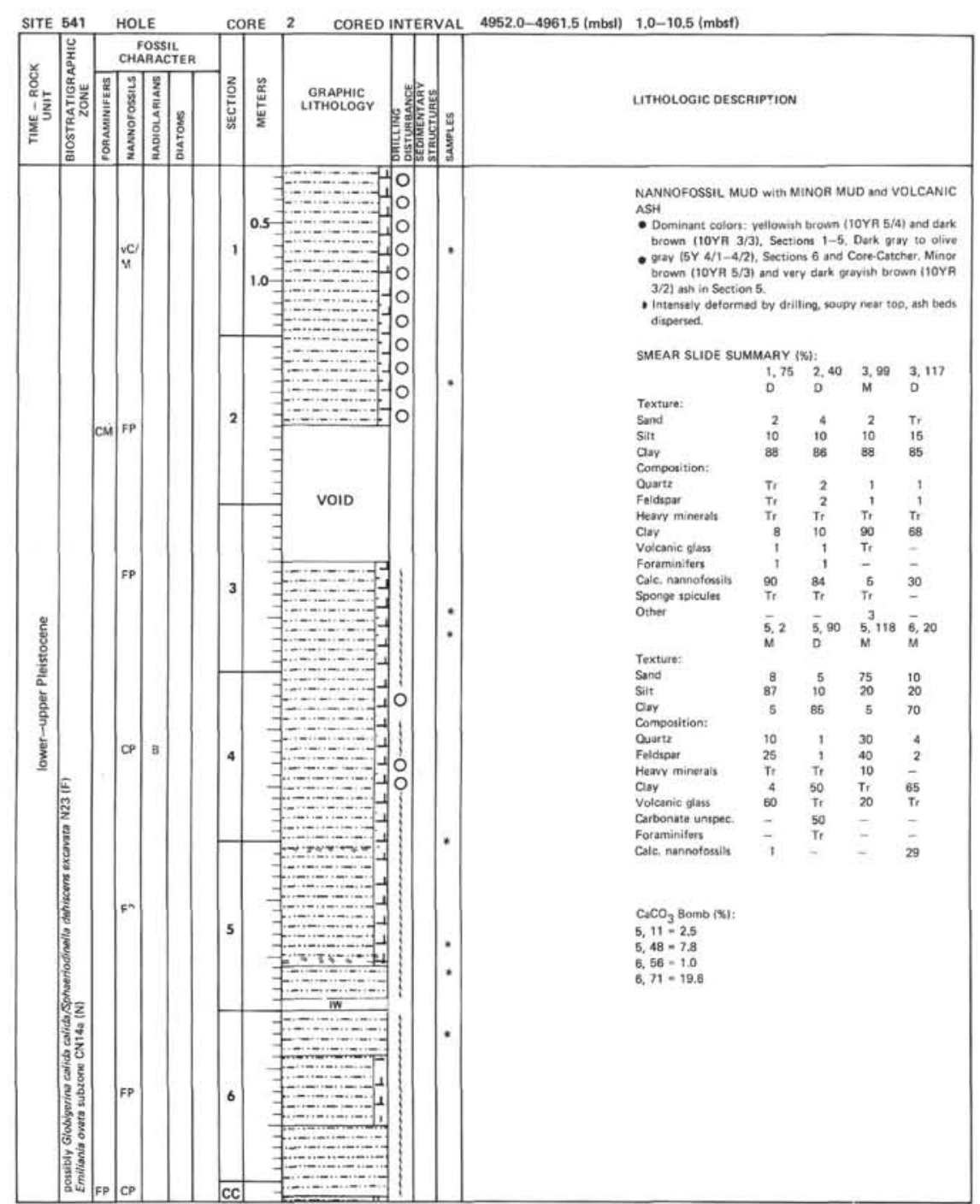

Information on core description sheets, for ALL sites, represents field notes taken aboard ship under time pressure. Some of this information has been refined in accord with postcruise findings, but production schedules prohibit definitive correlation of these sheets with subsequent findings. Thus the reader should be alerted to the occasional ambiguity or discrepancy. 

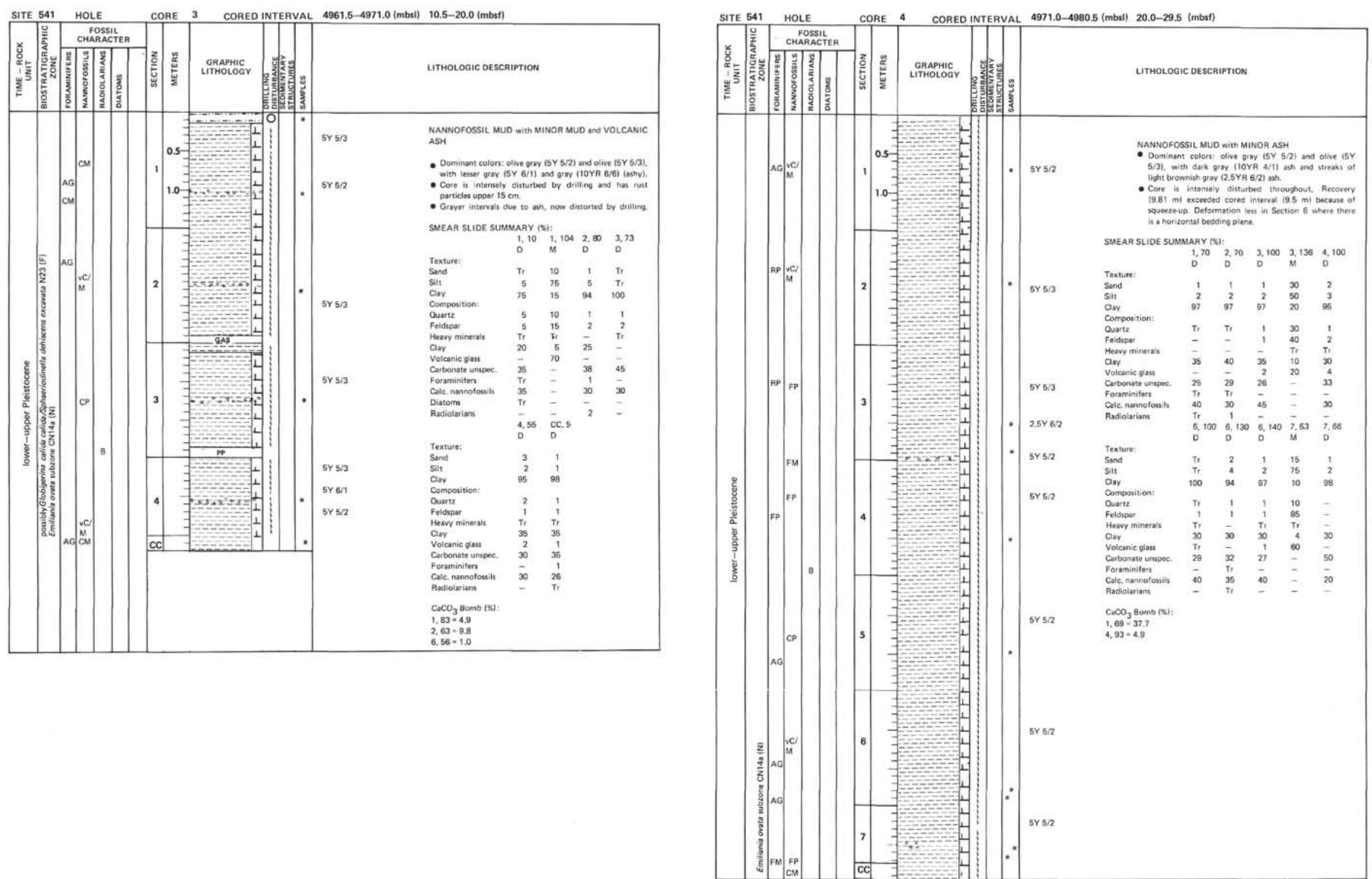

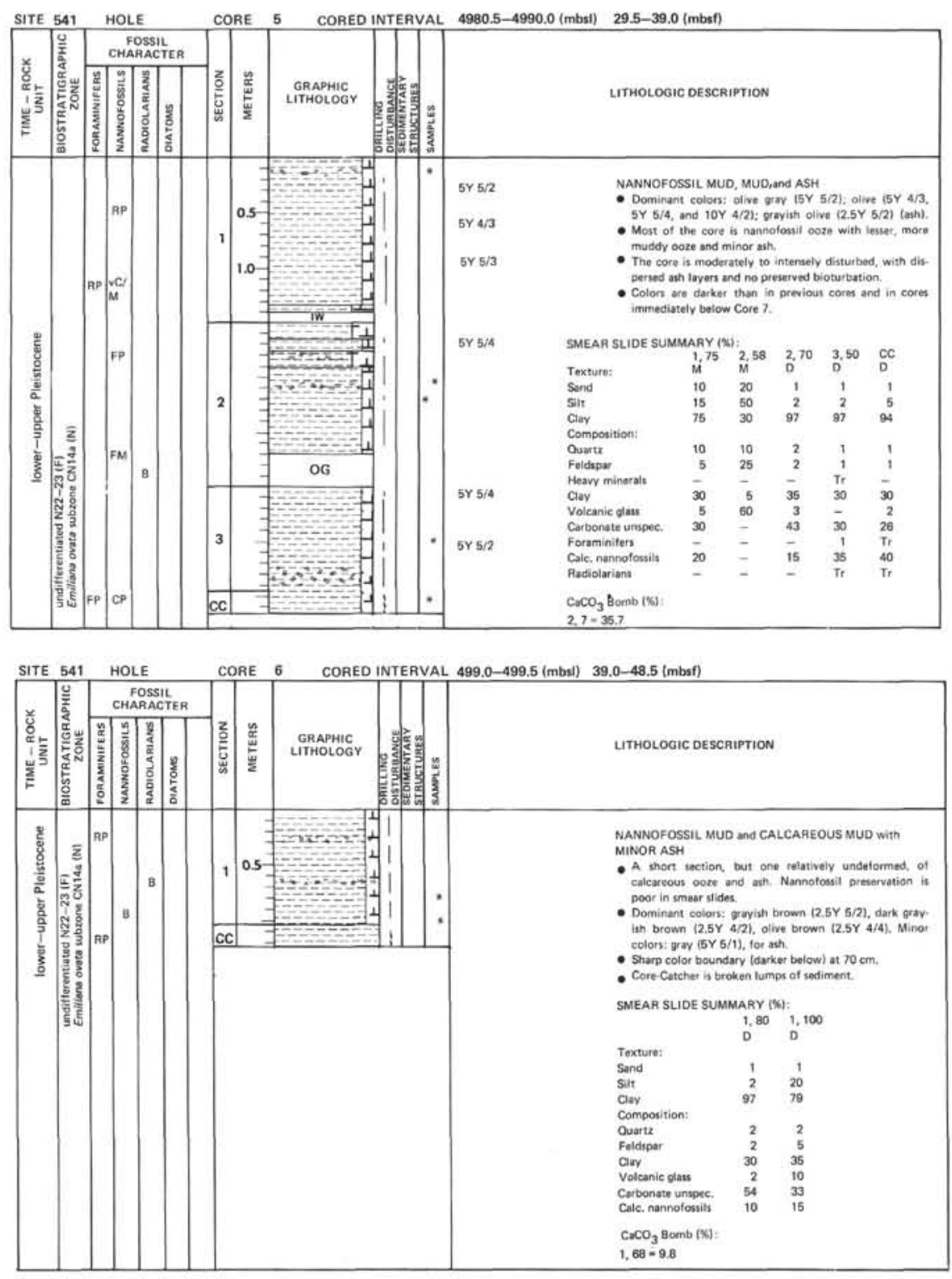

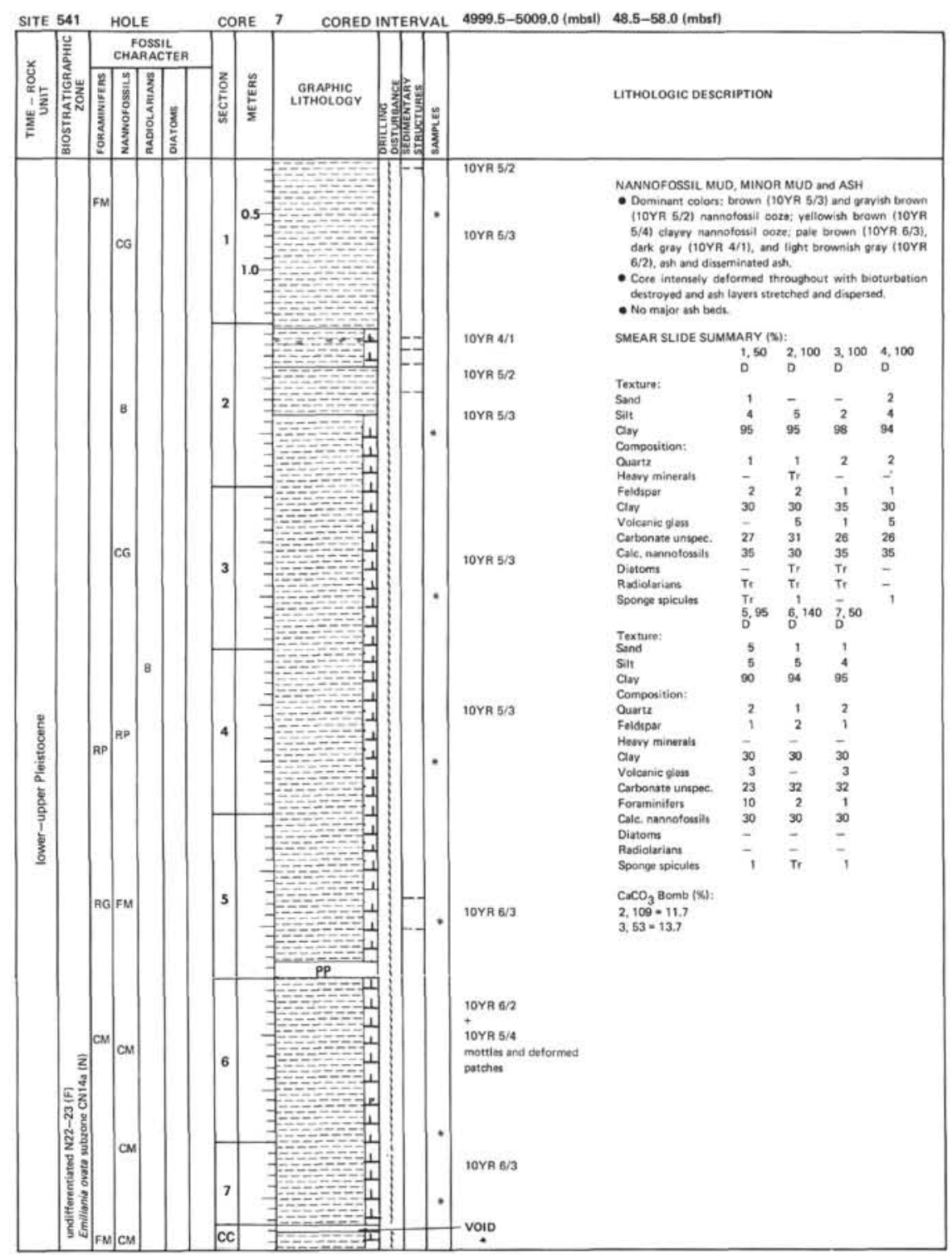




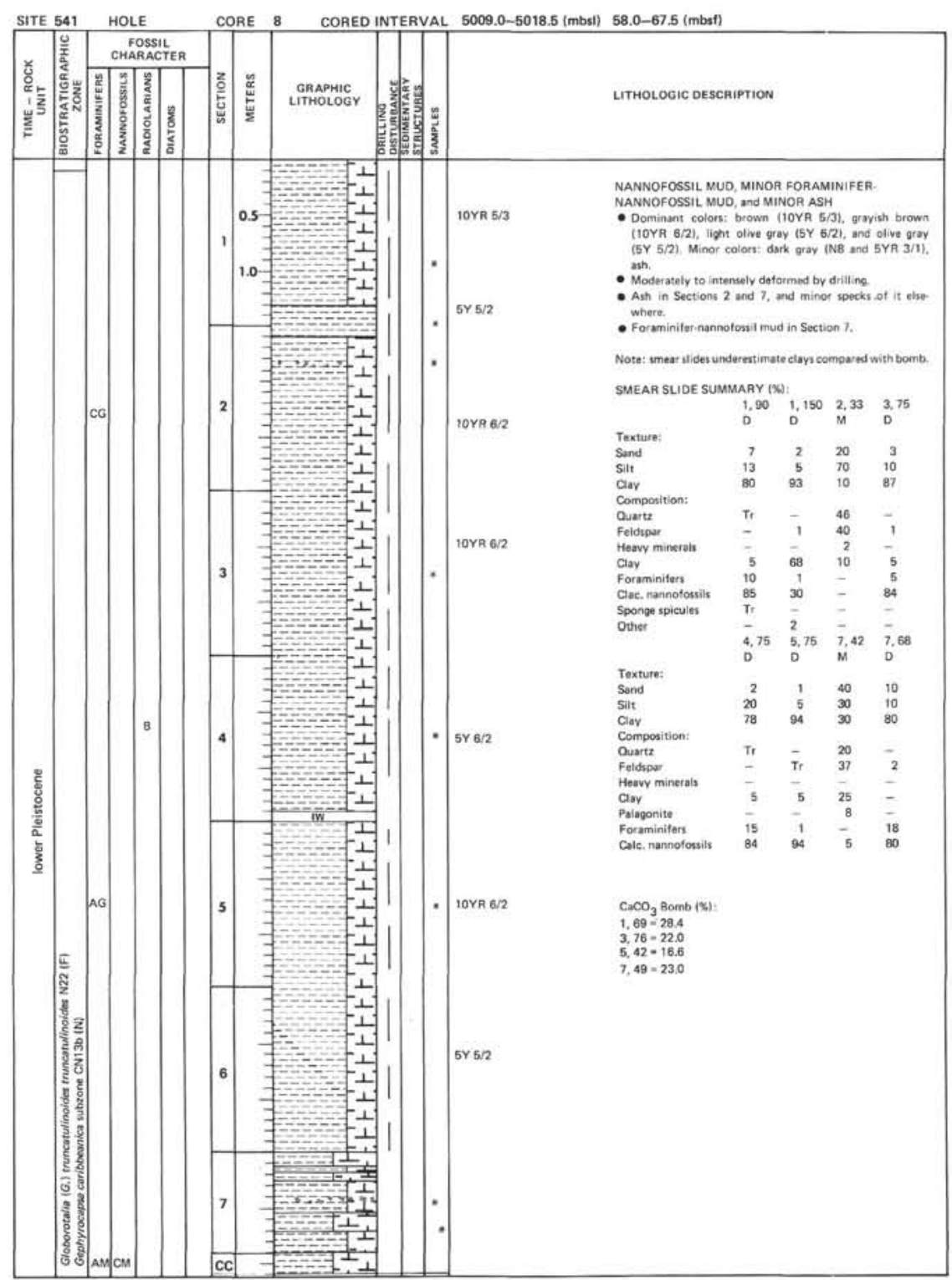

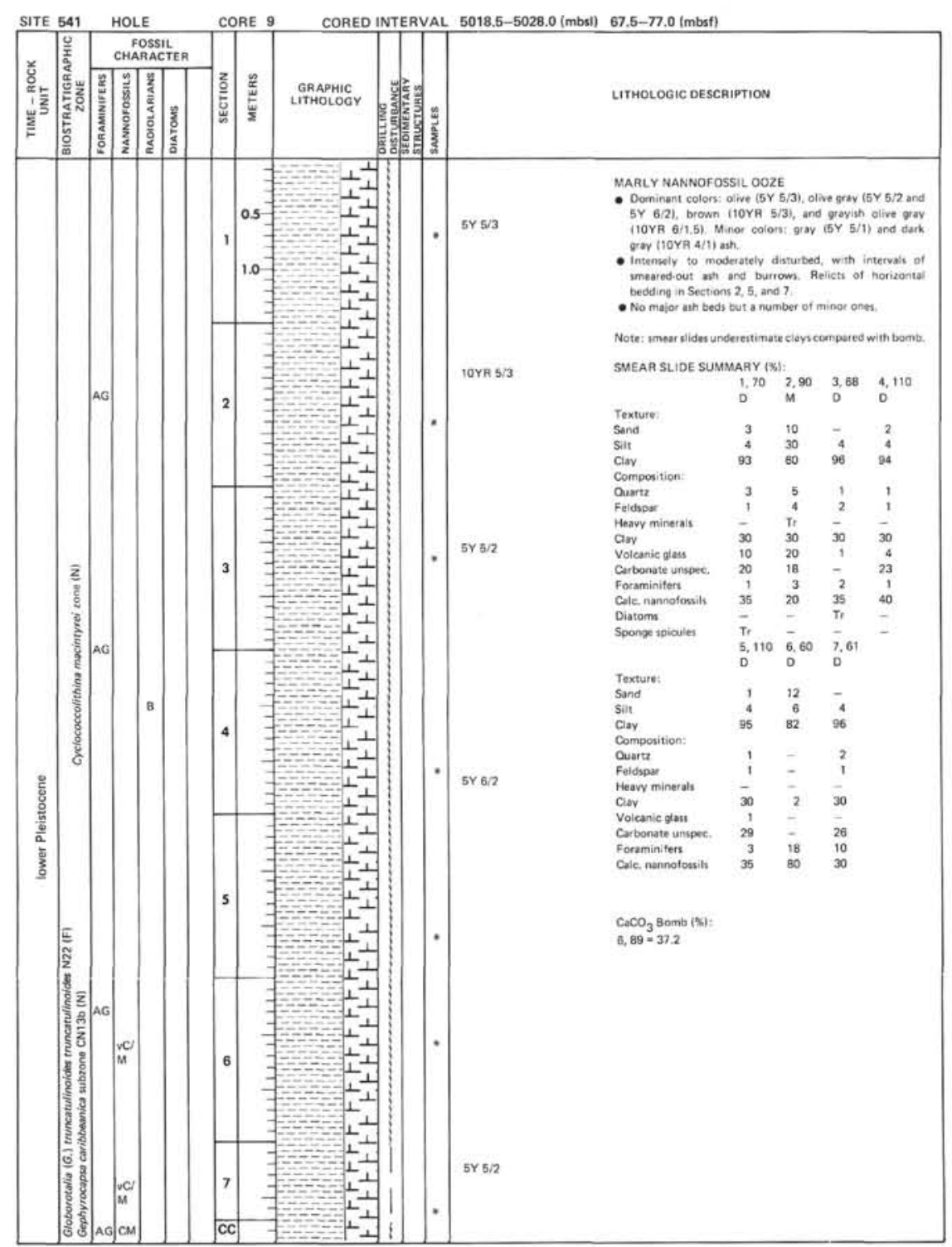



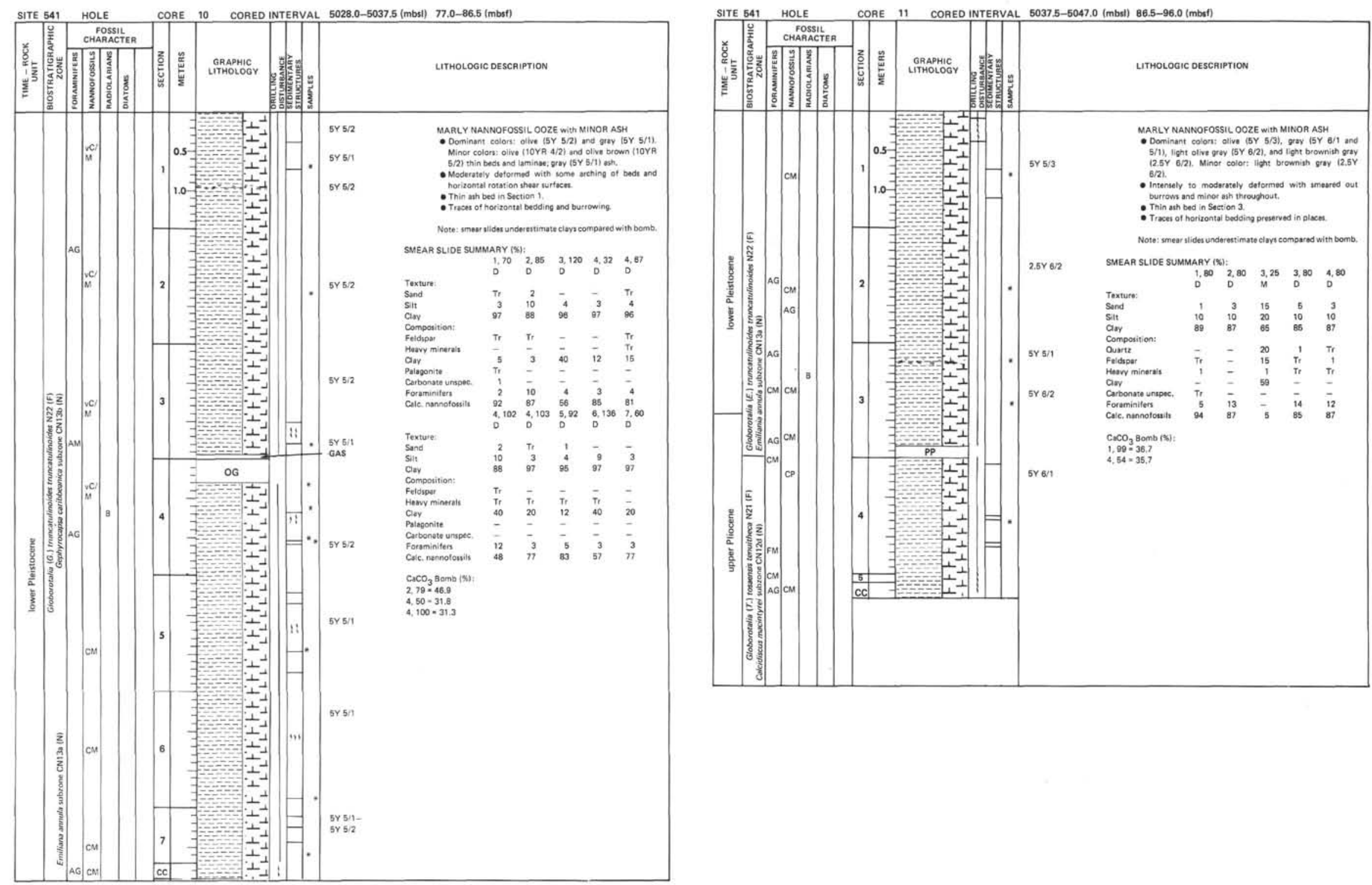

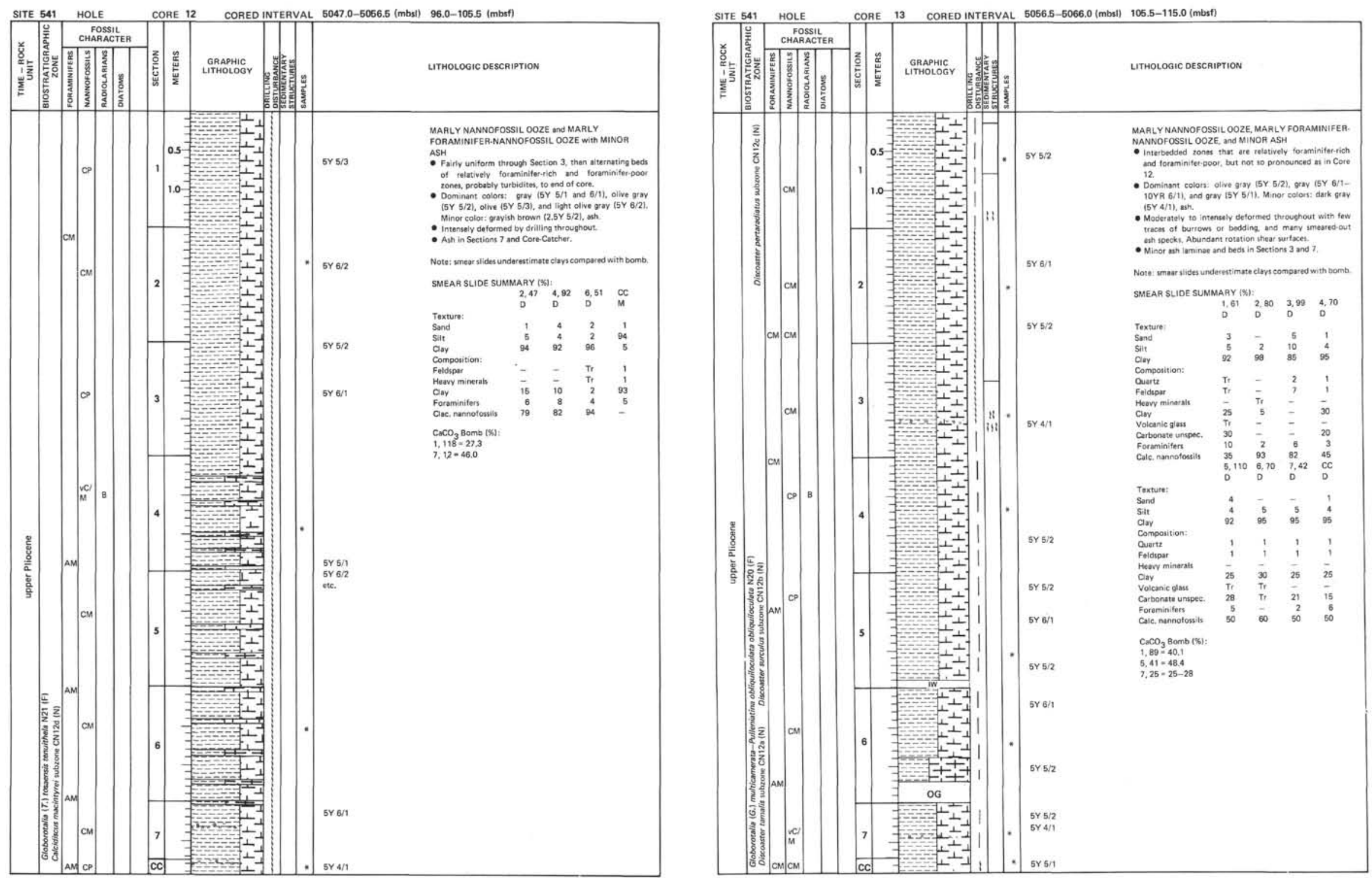

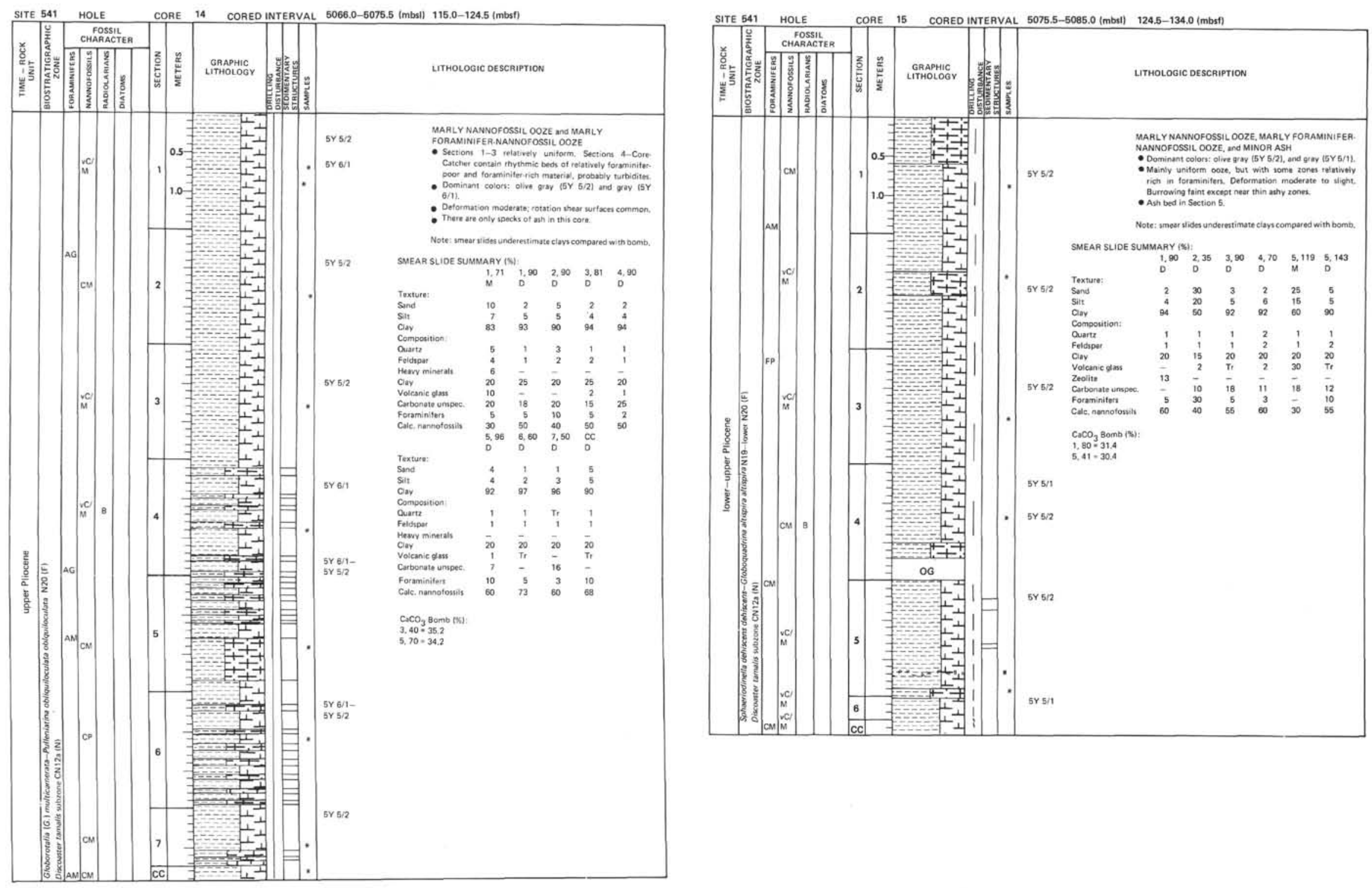

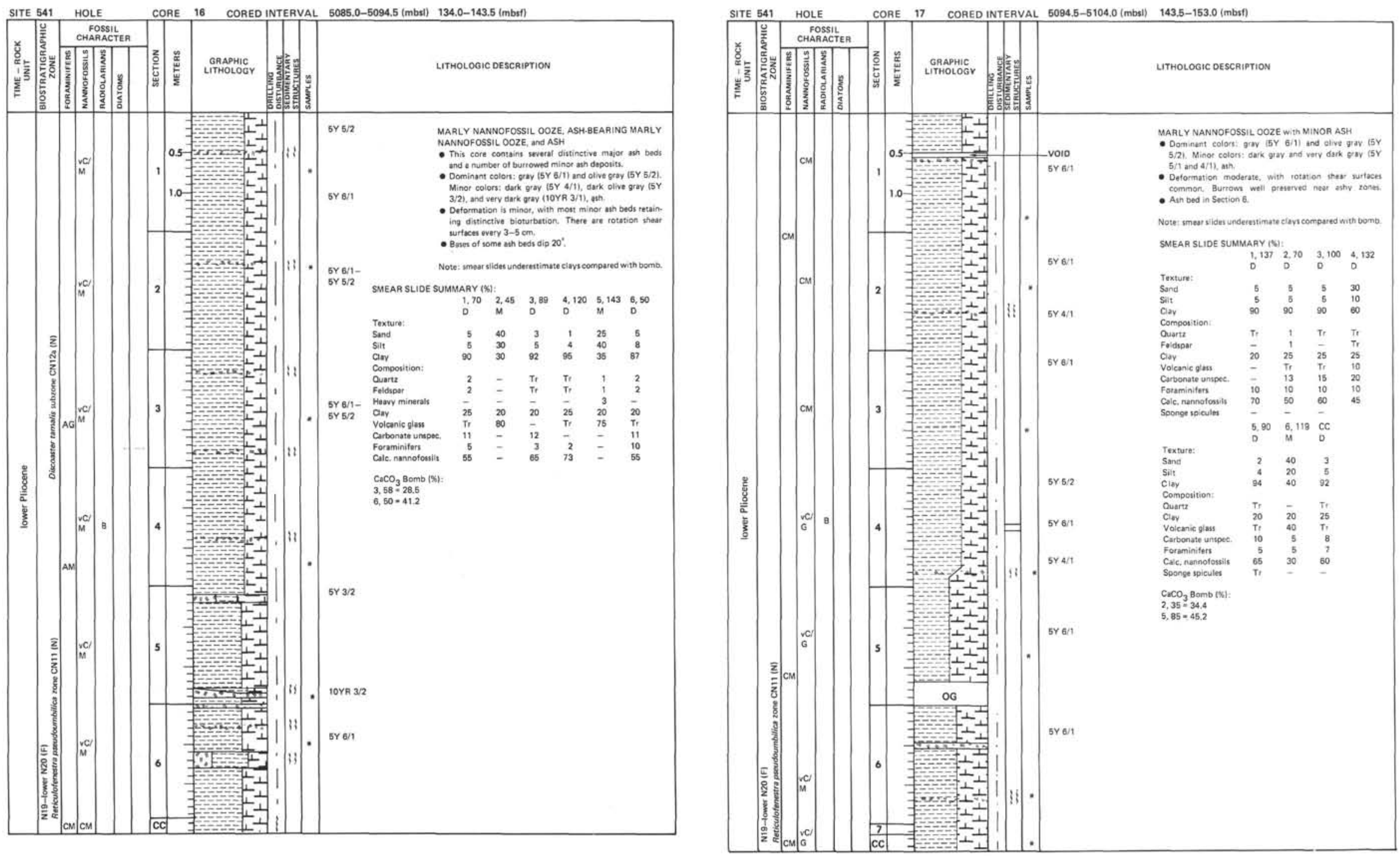

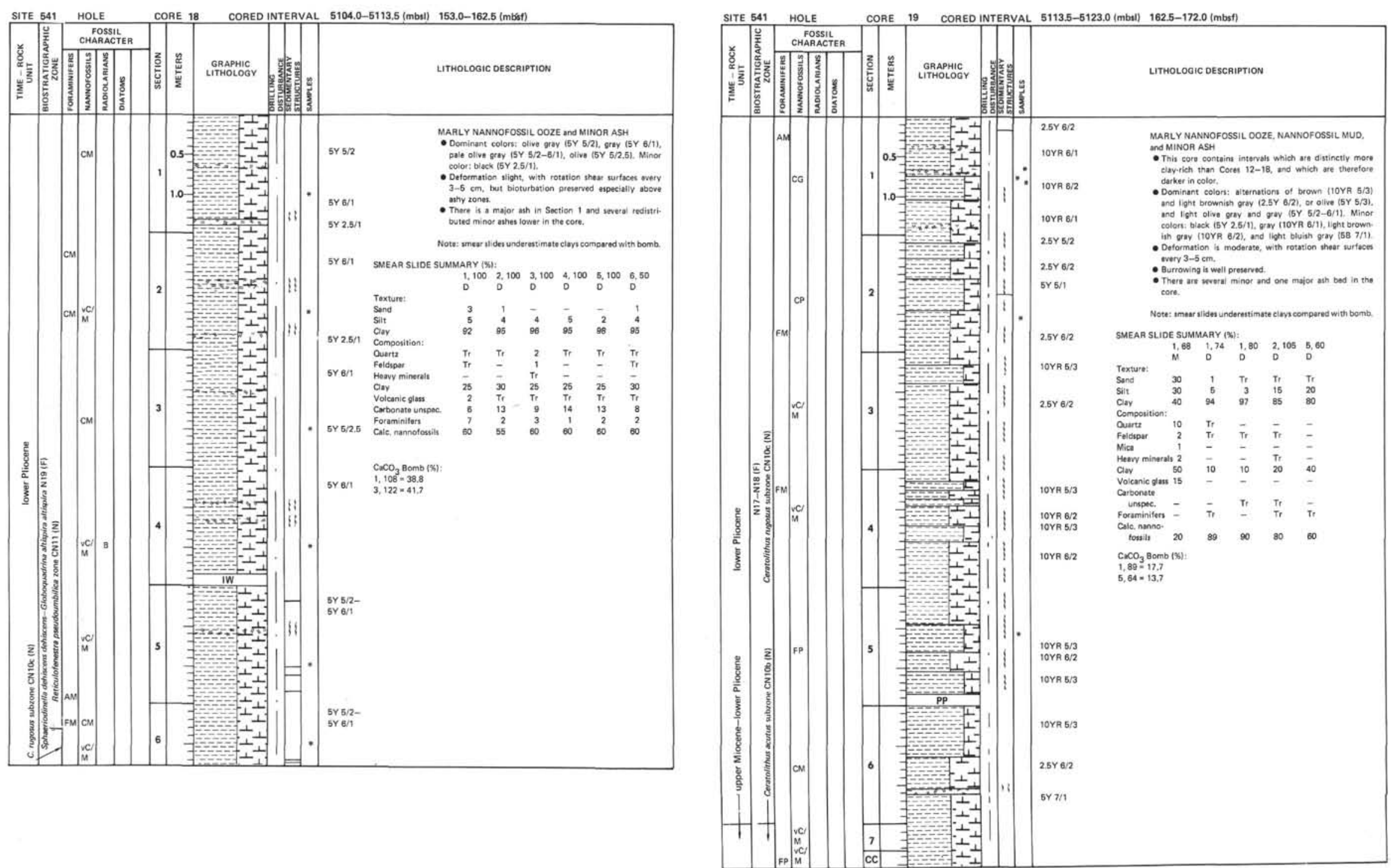


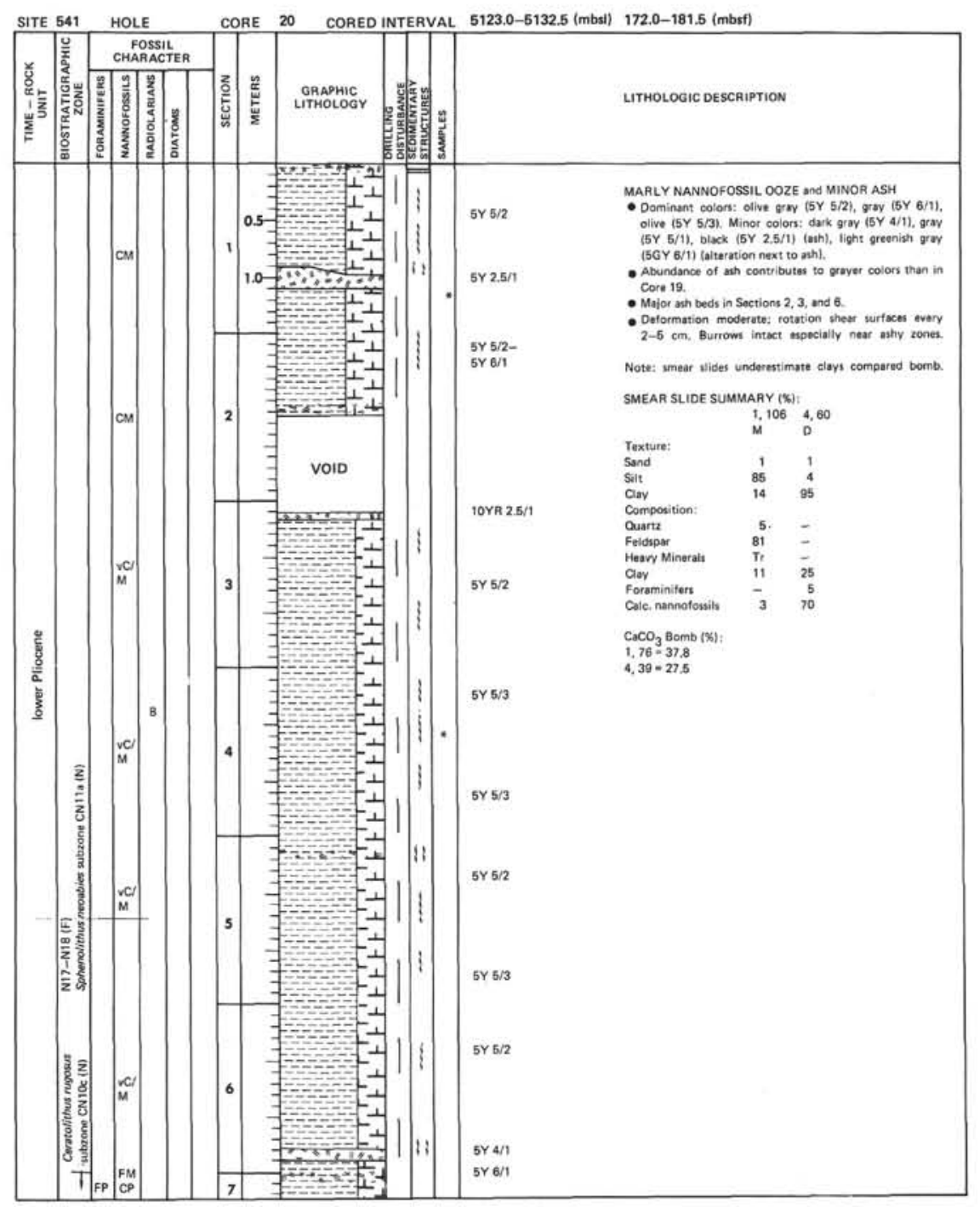

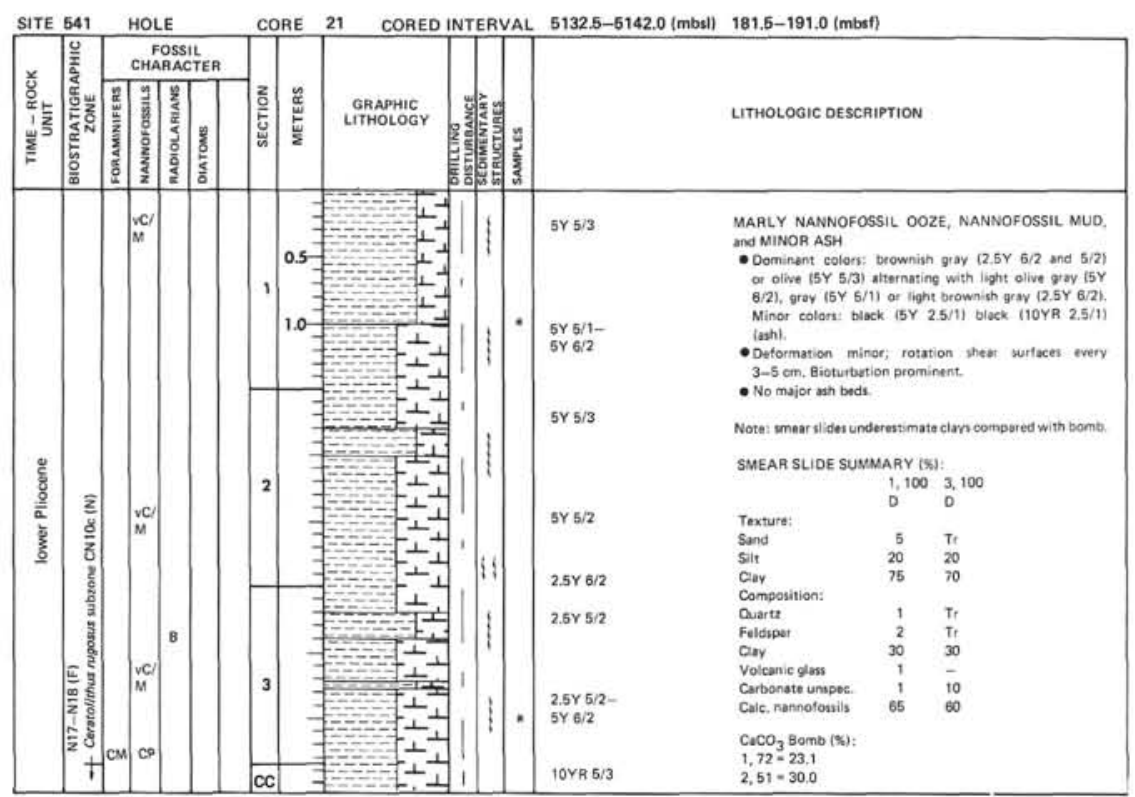



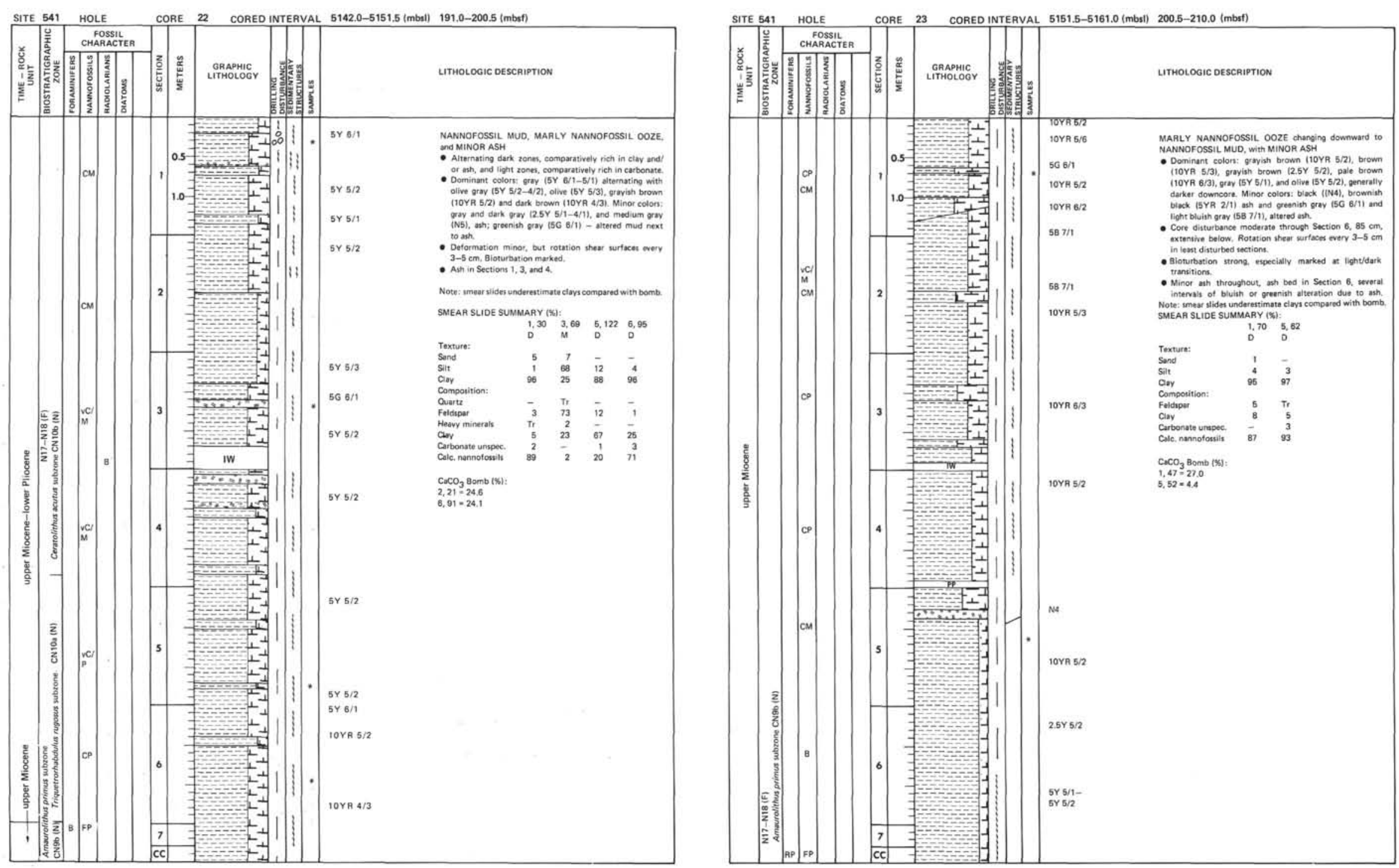

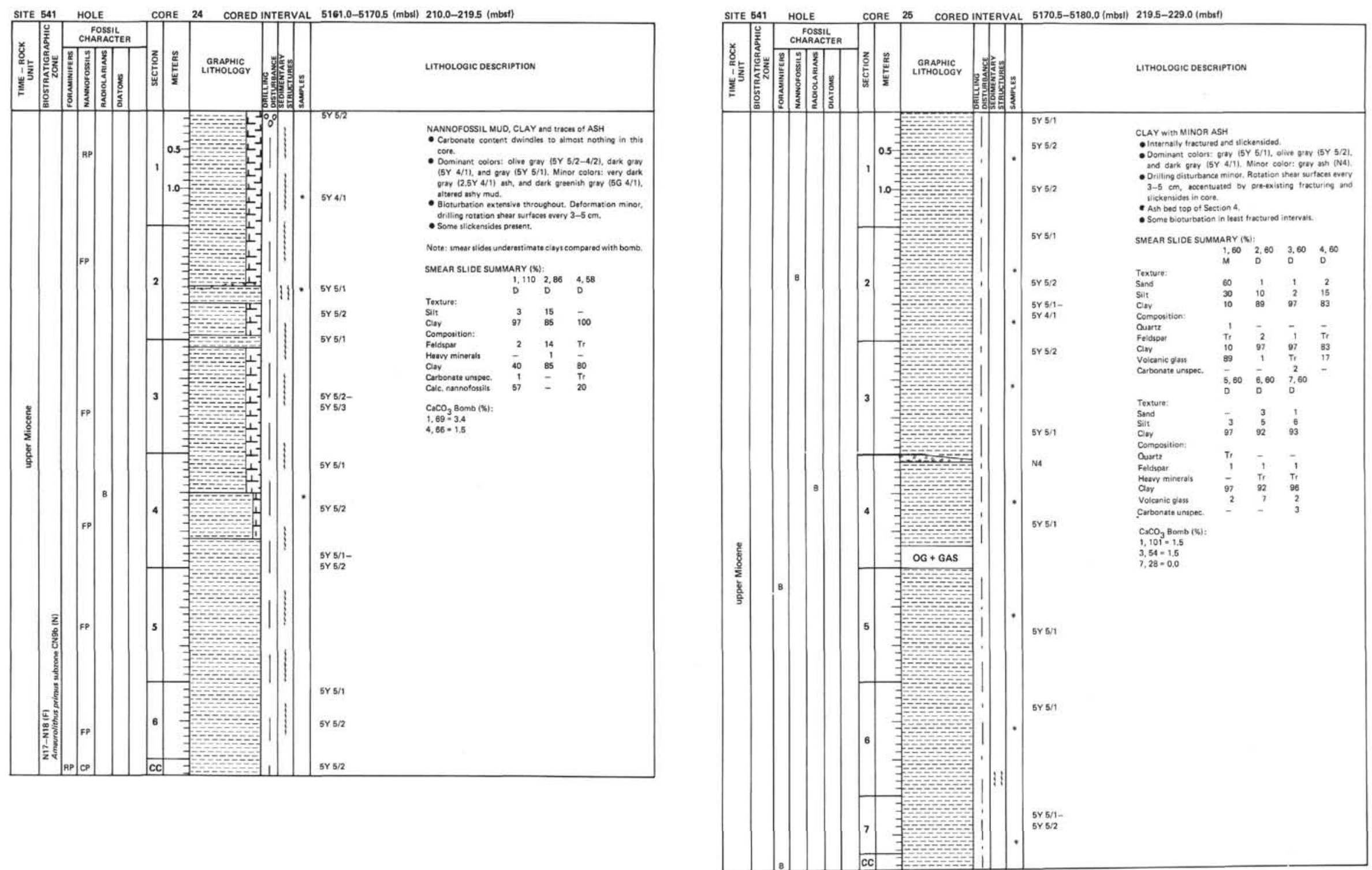

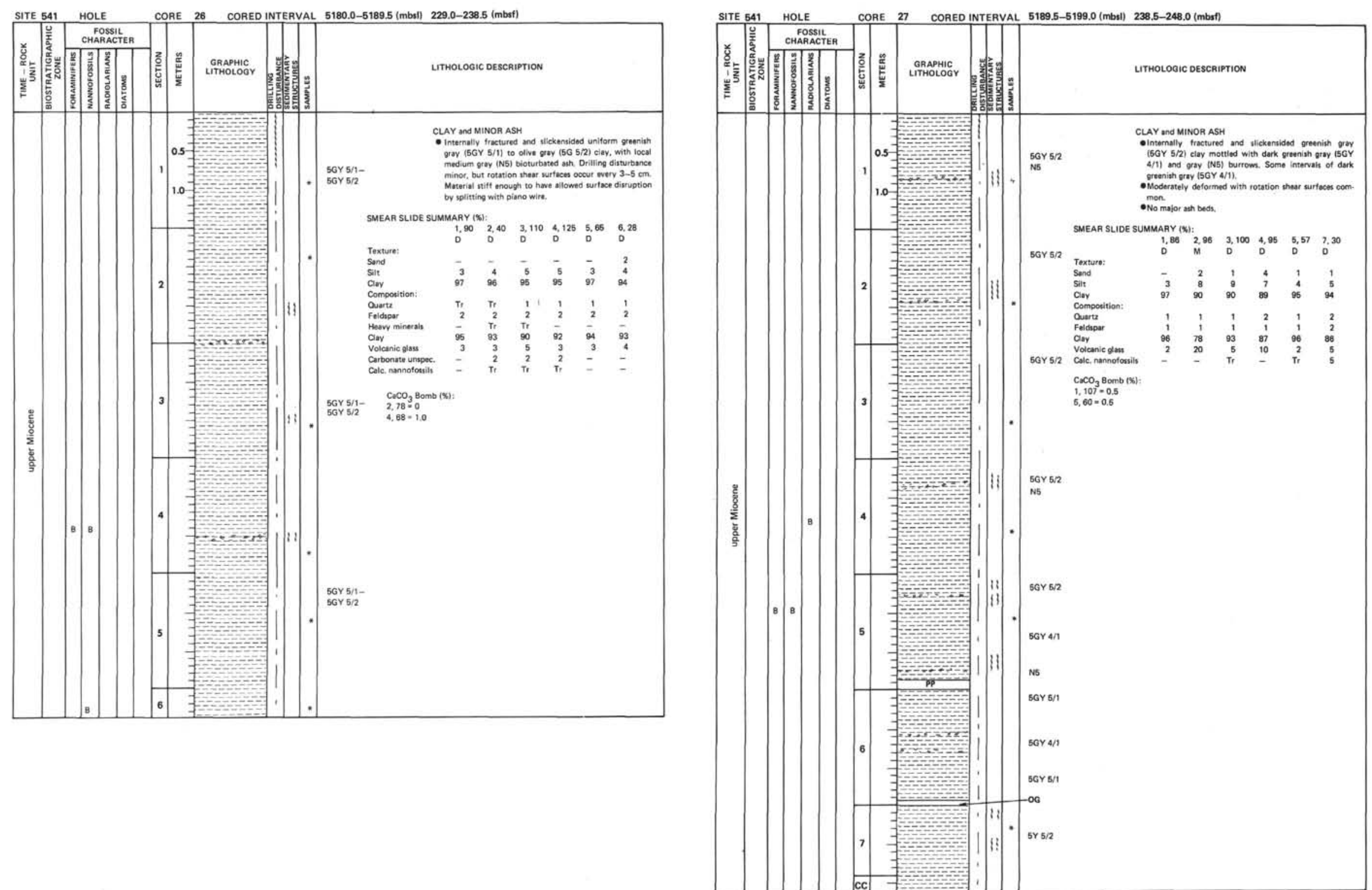

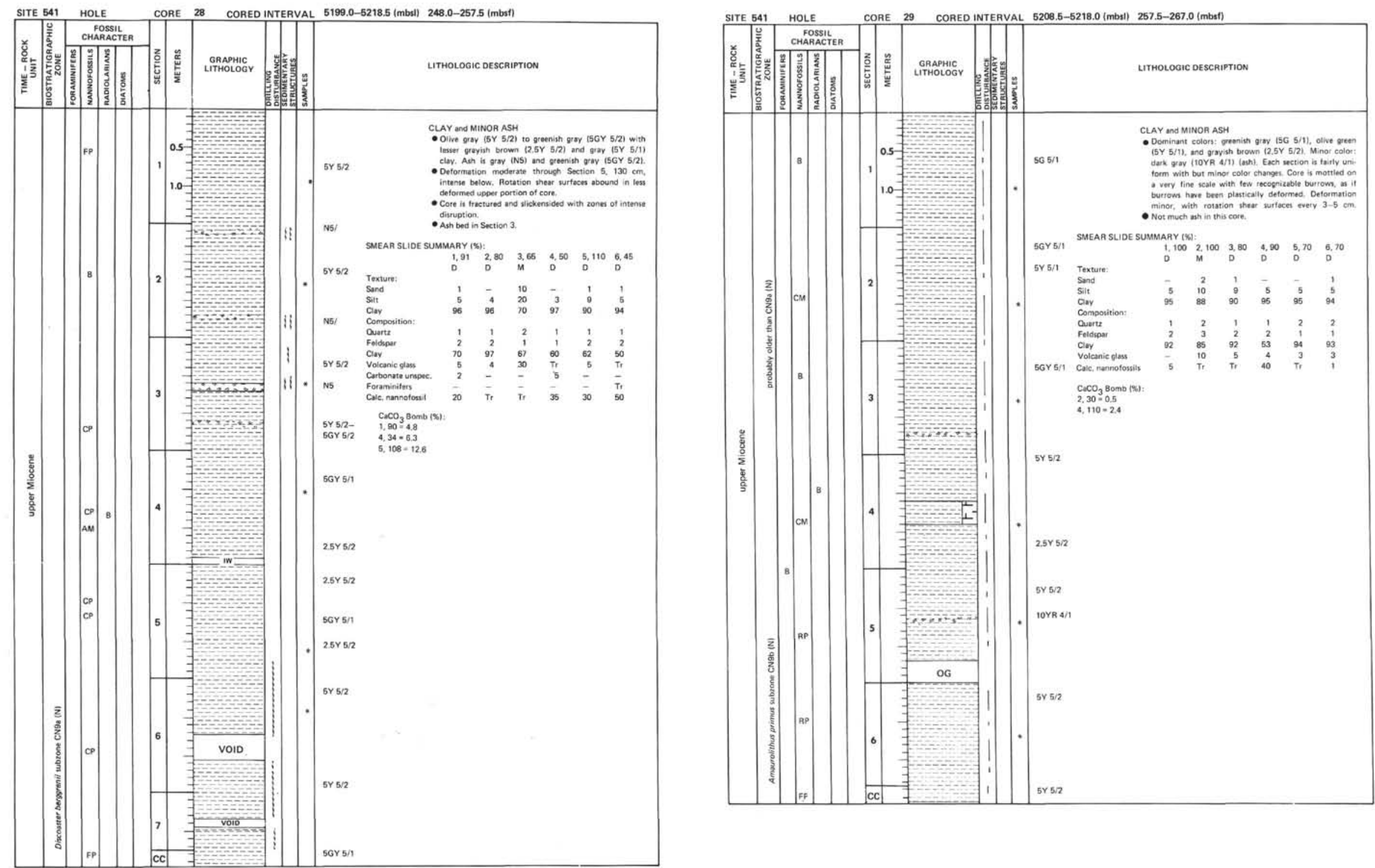


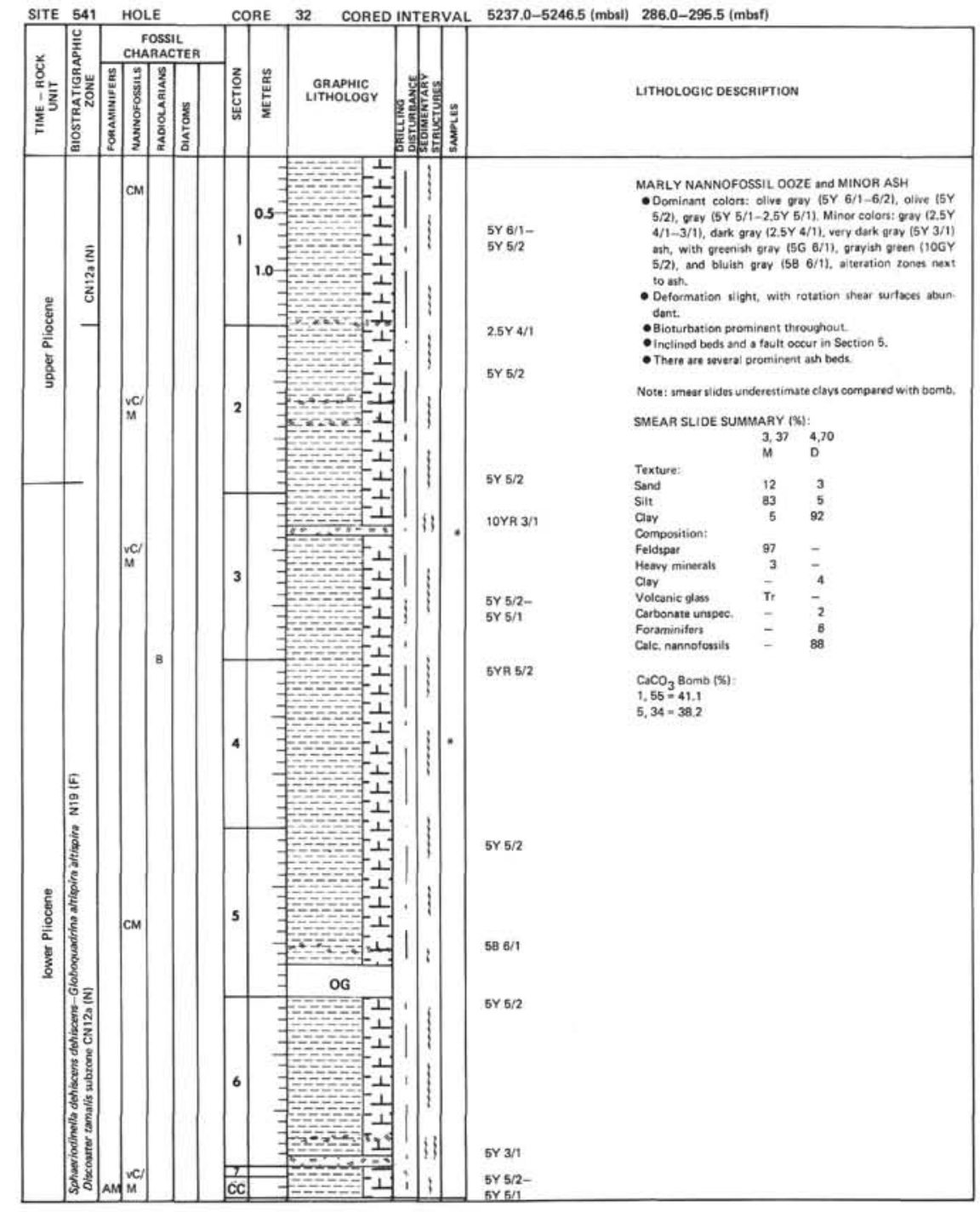

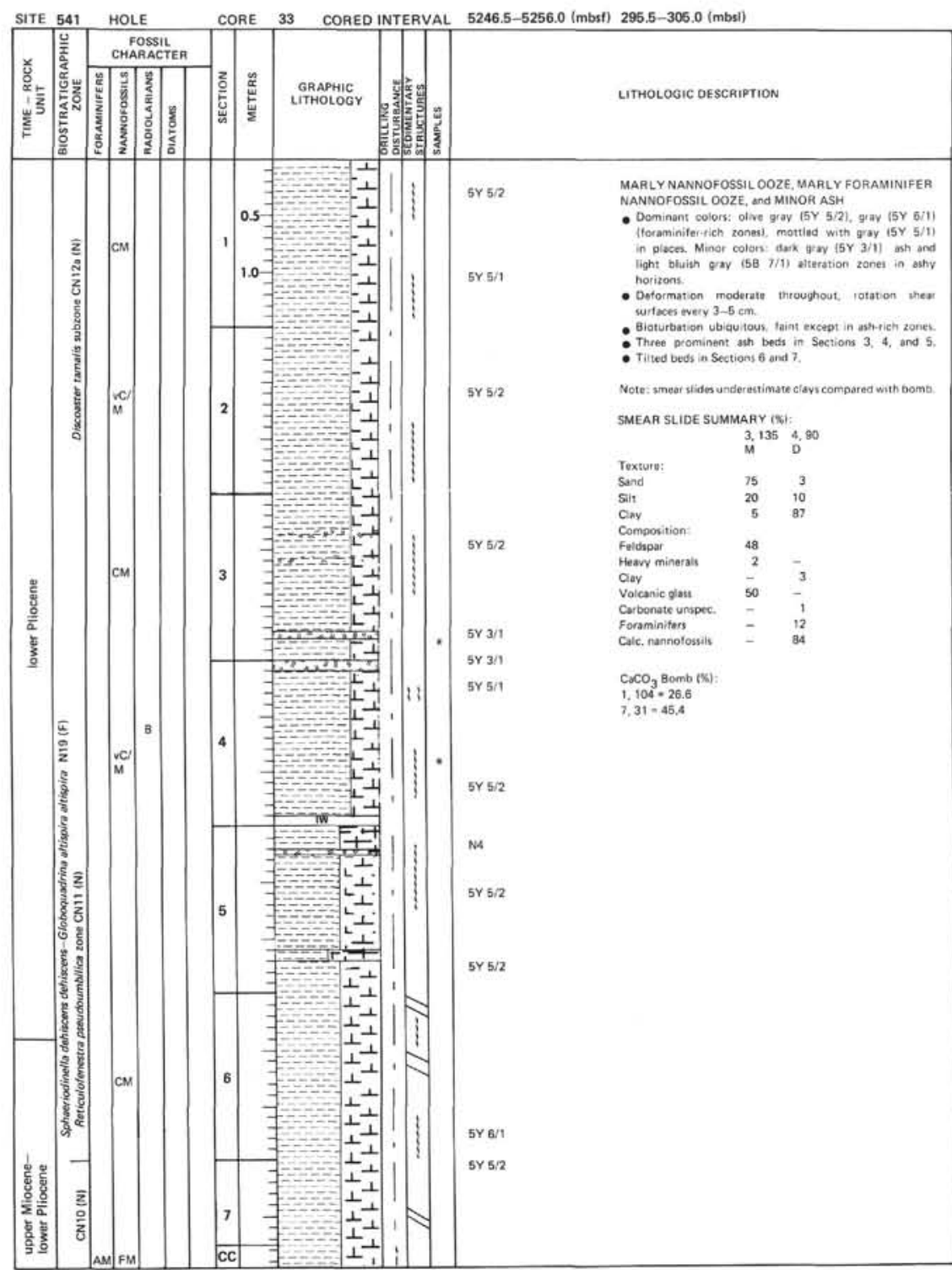



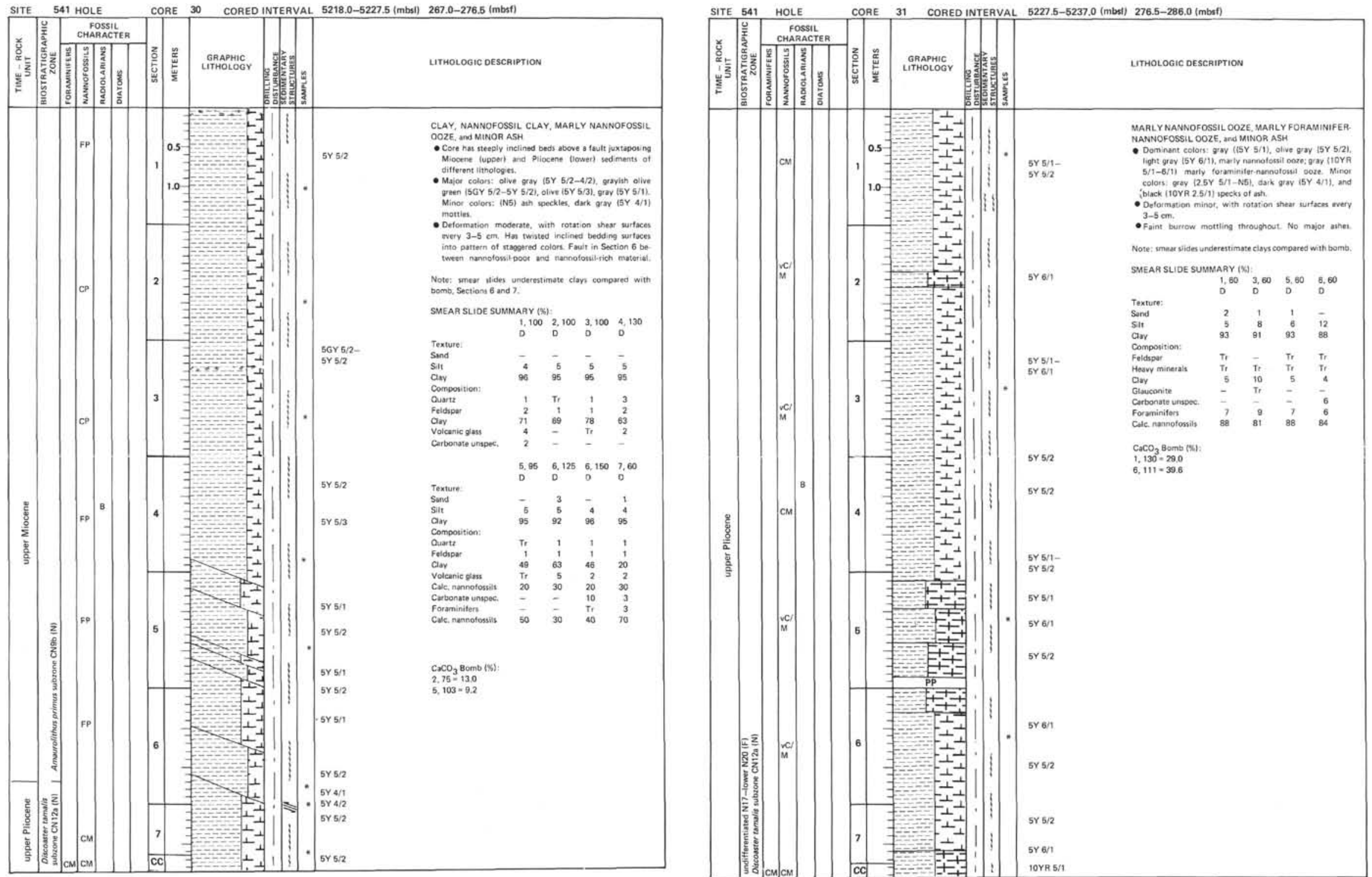


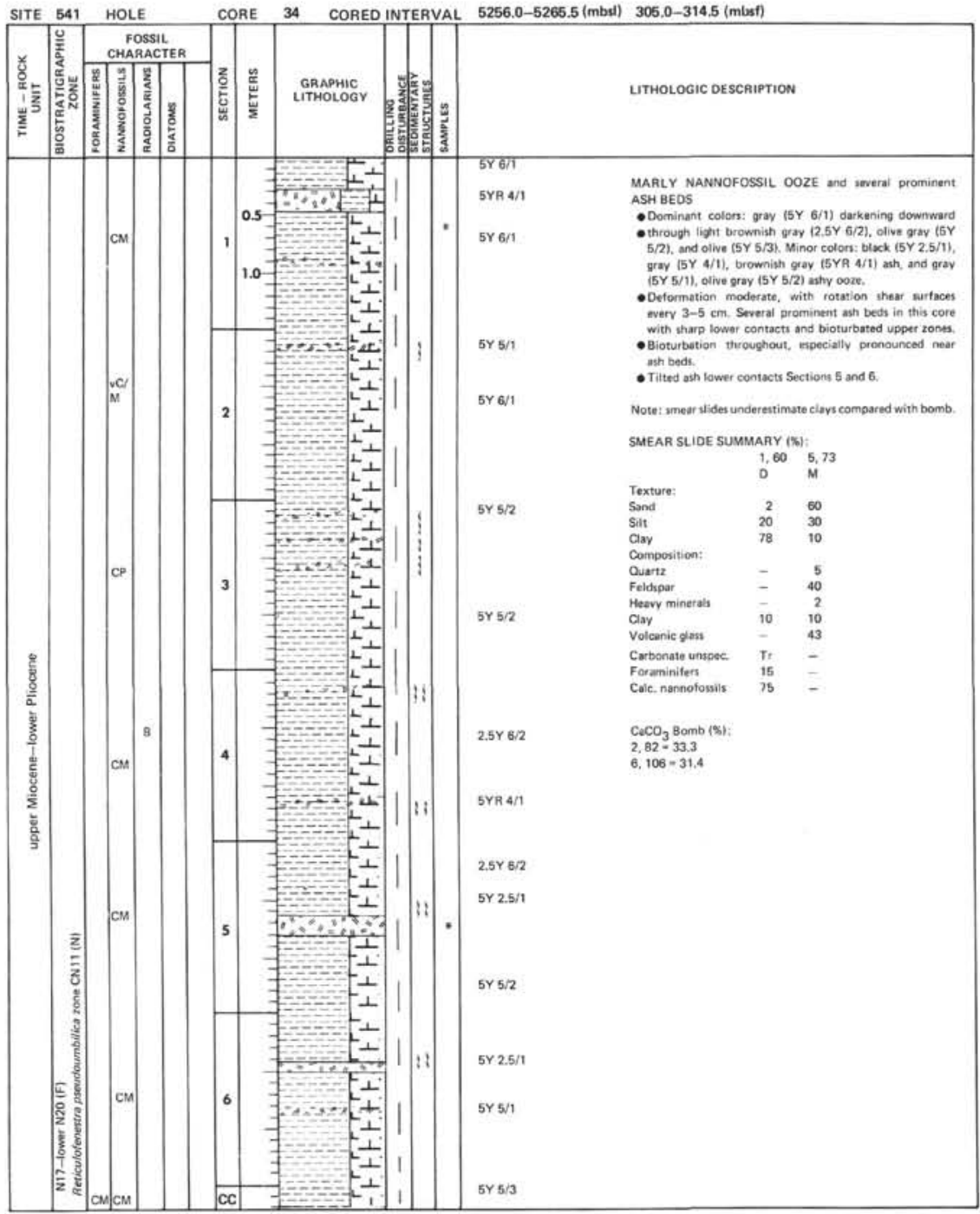

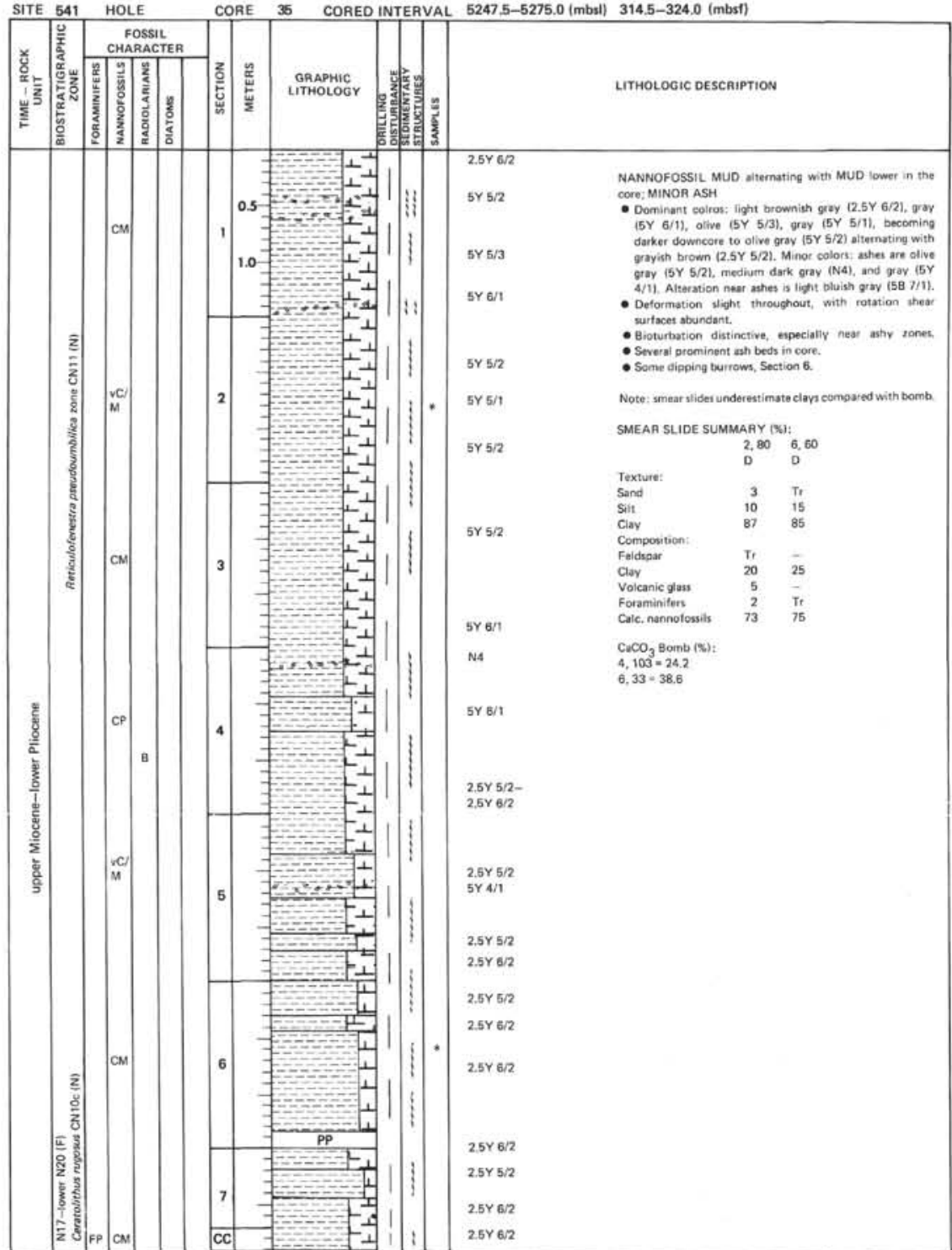



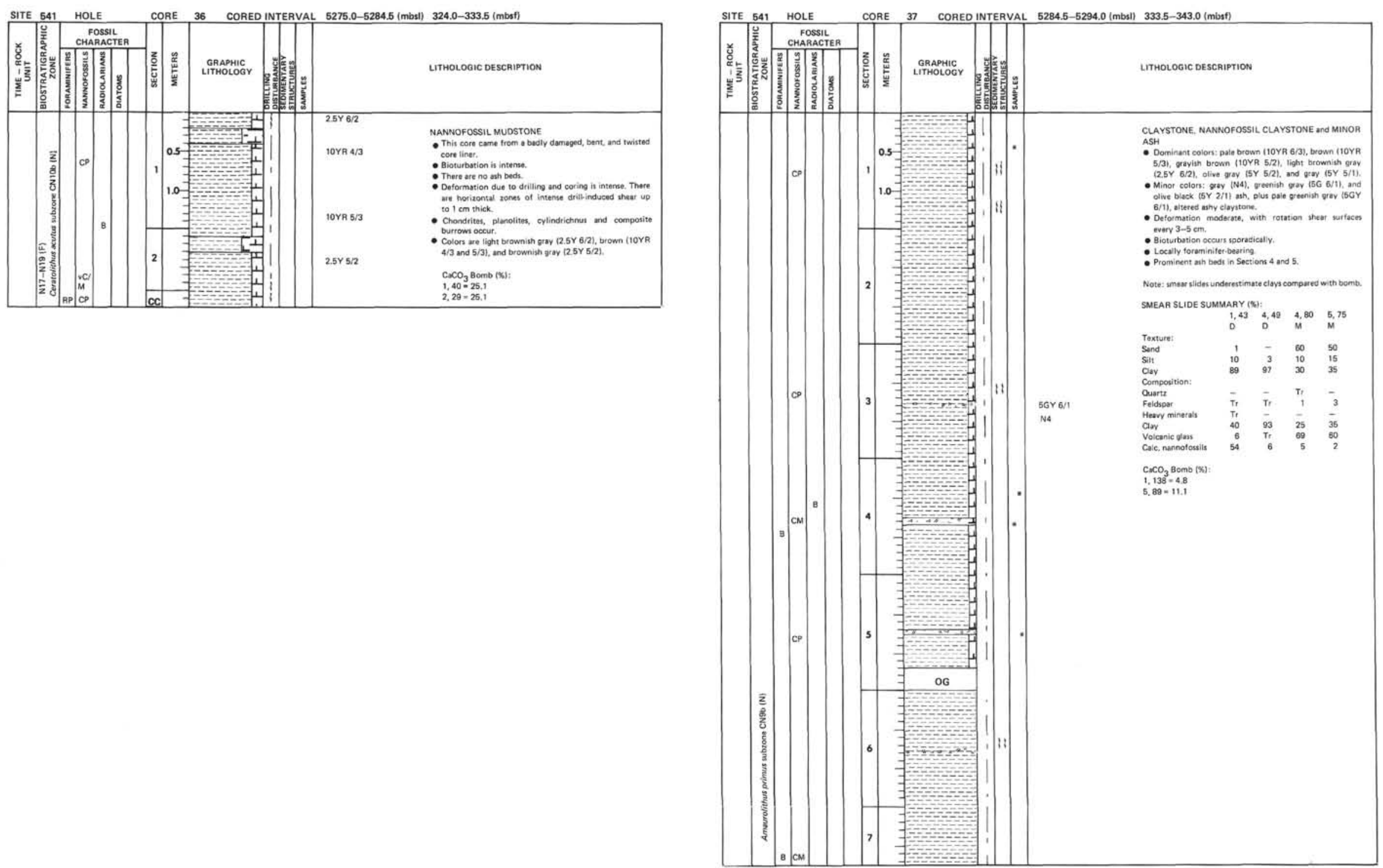

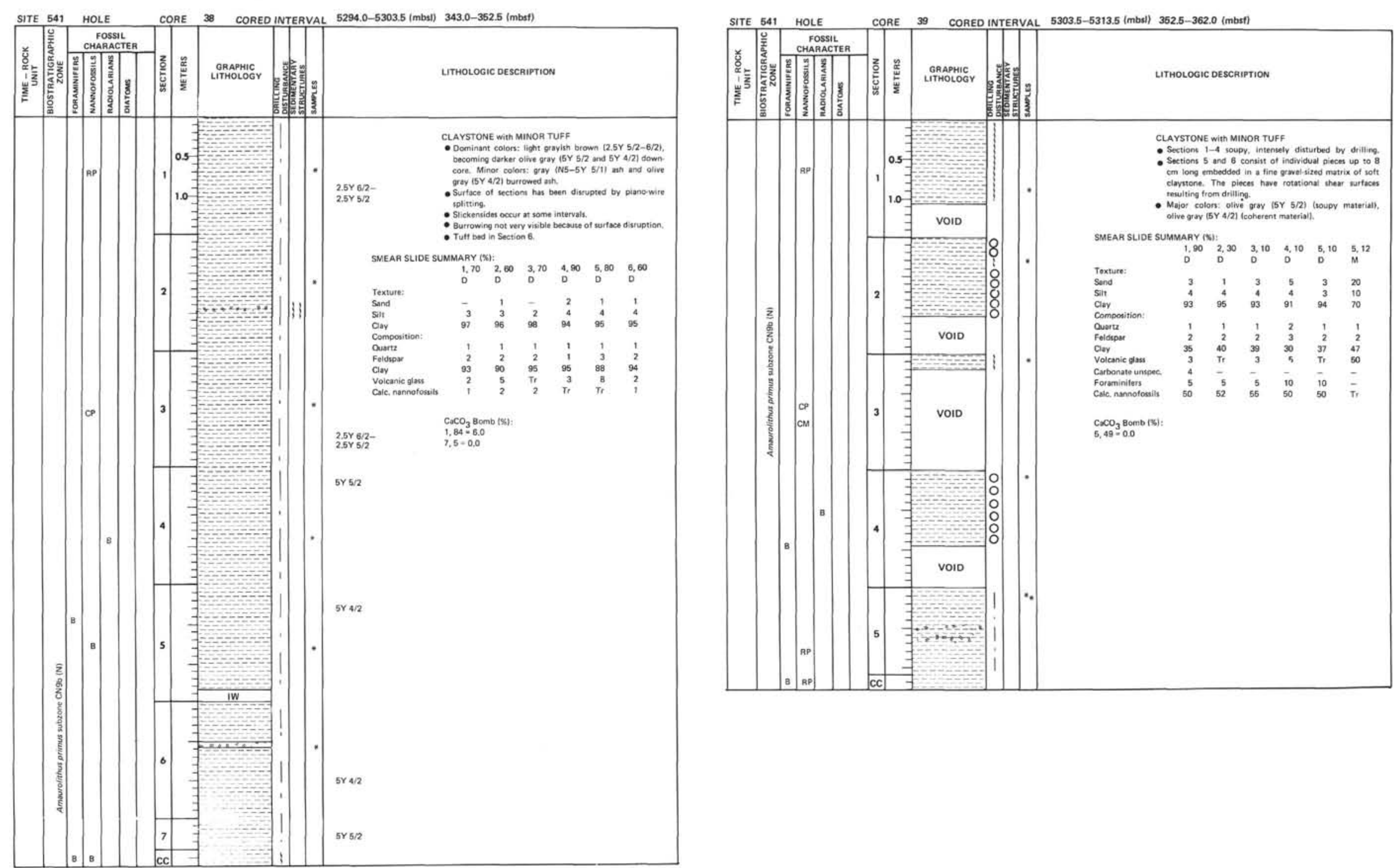

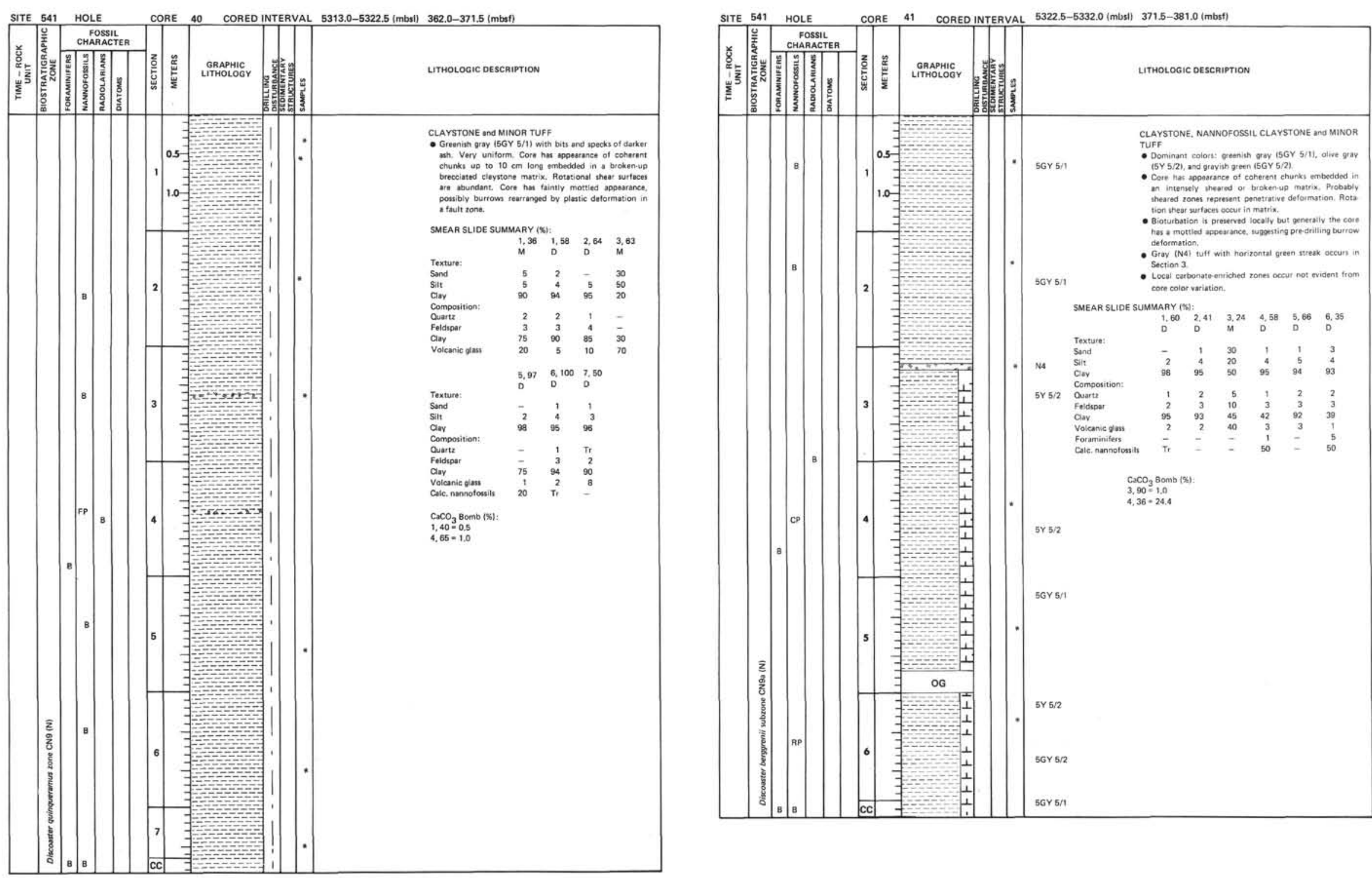

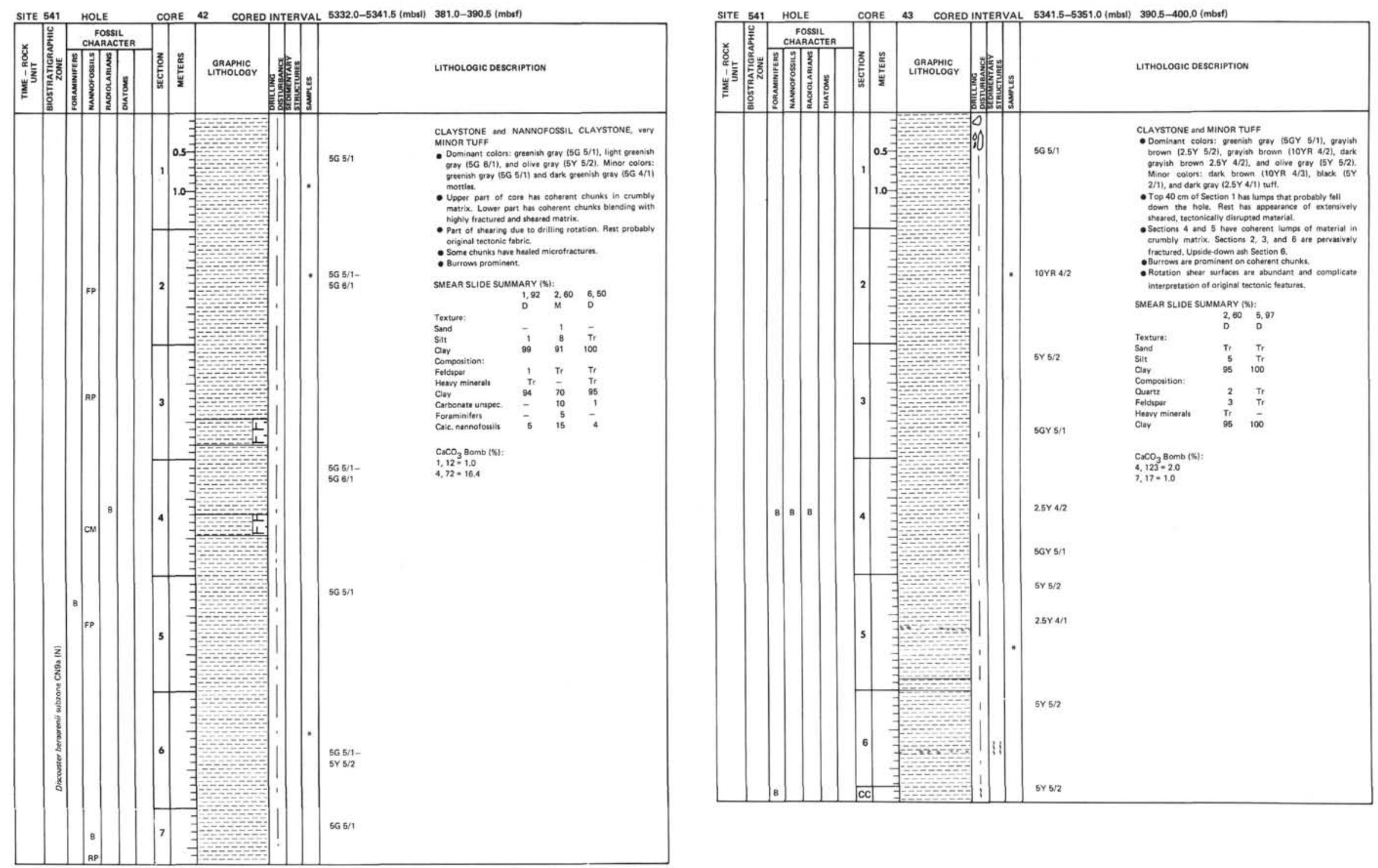

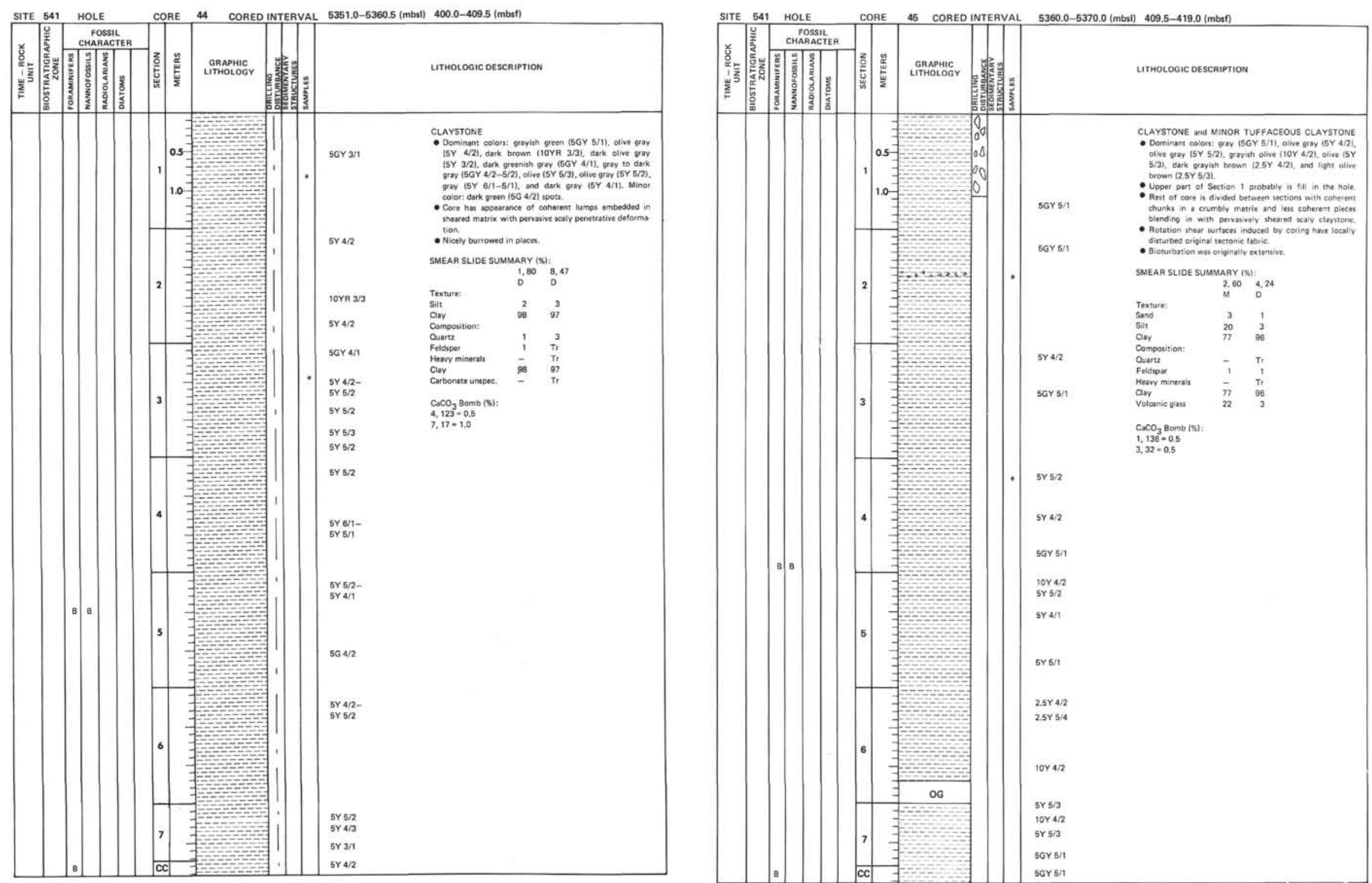

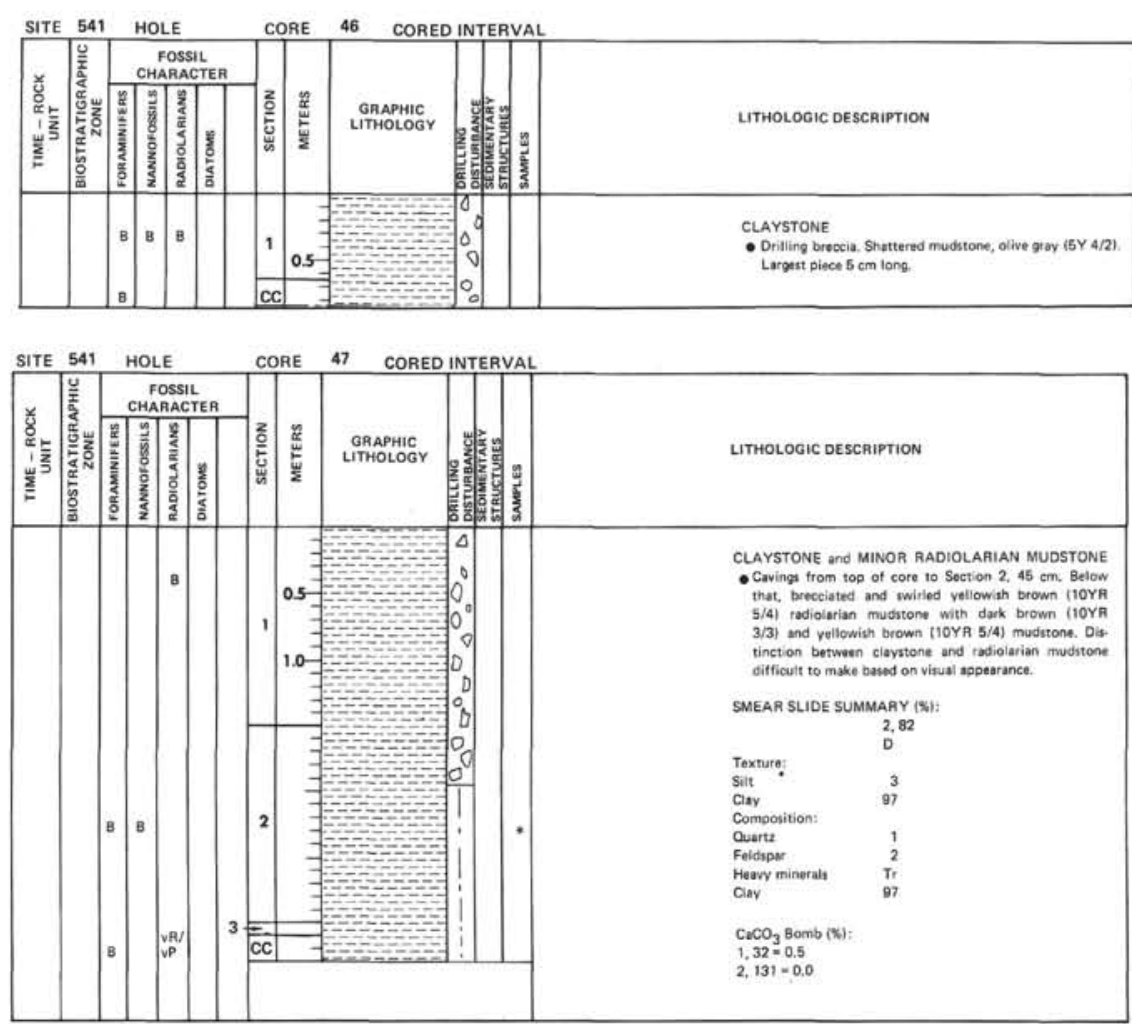

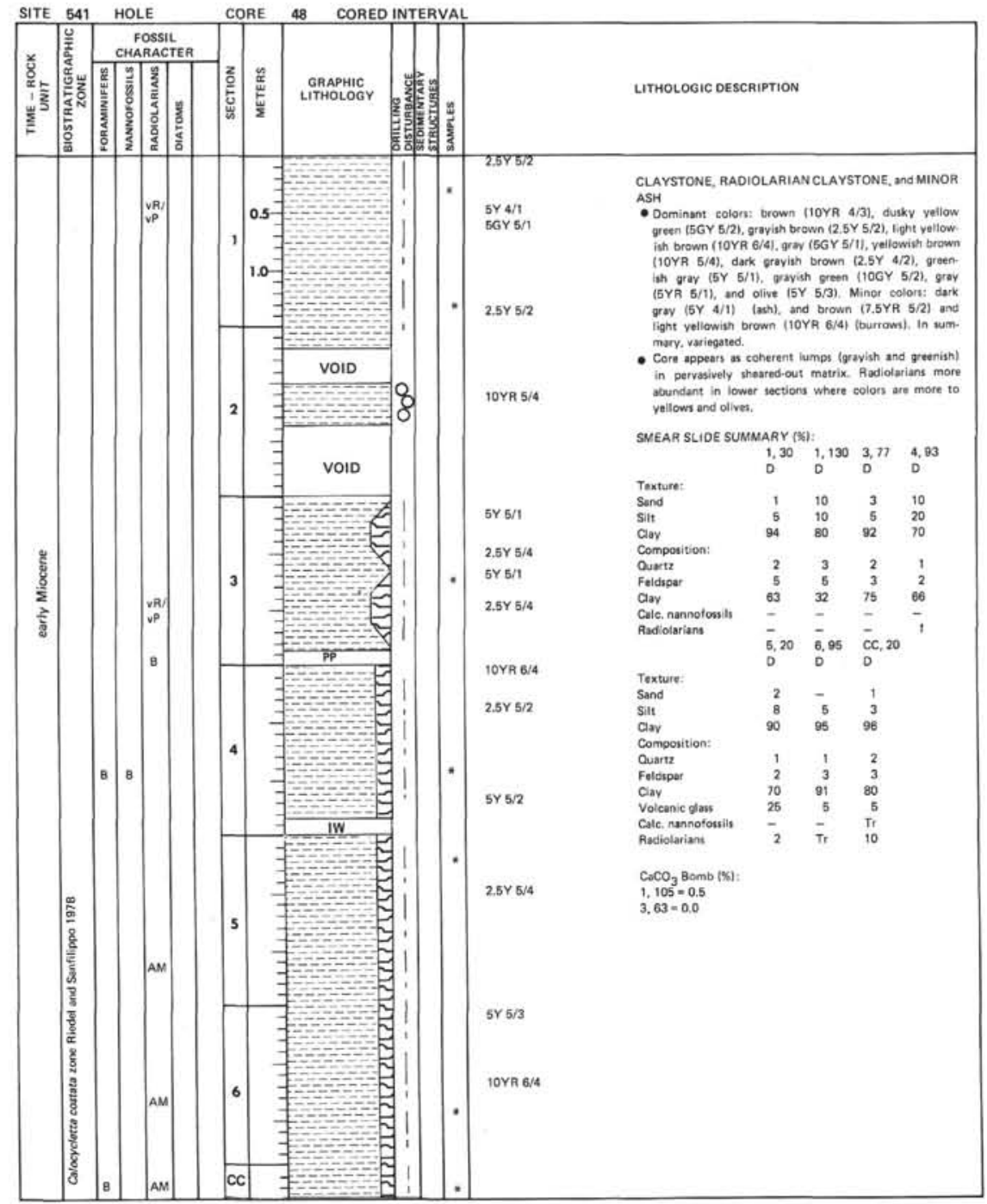




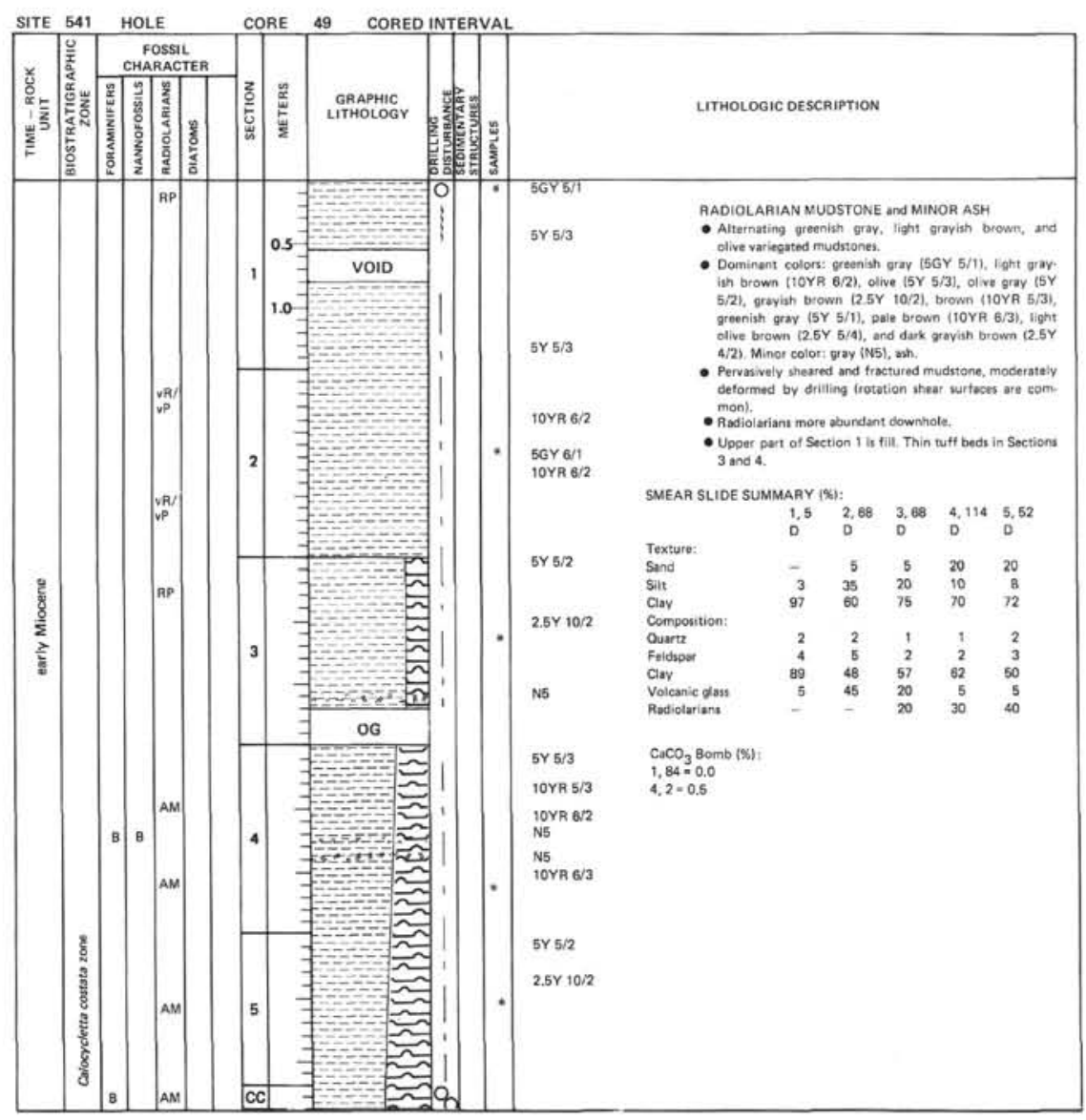

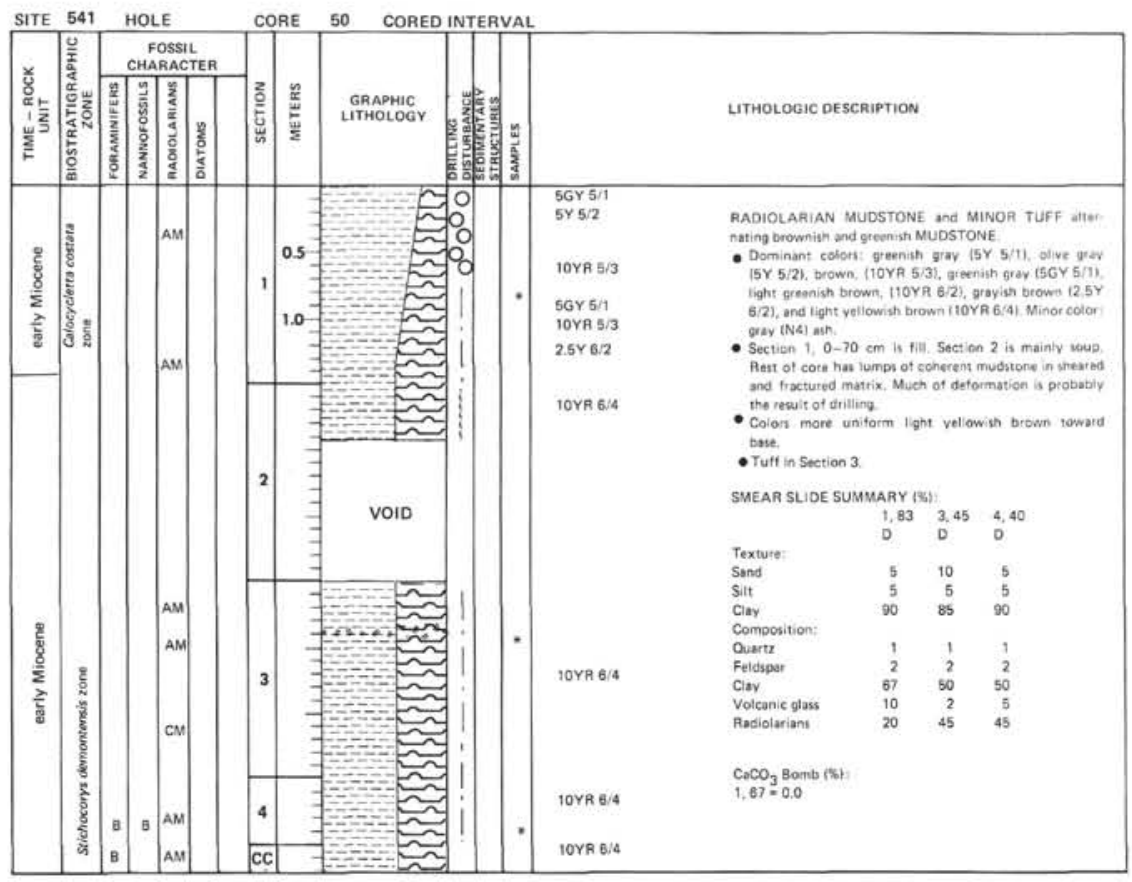




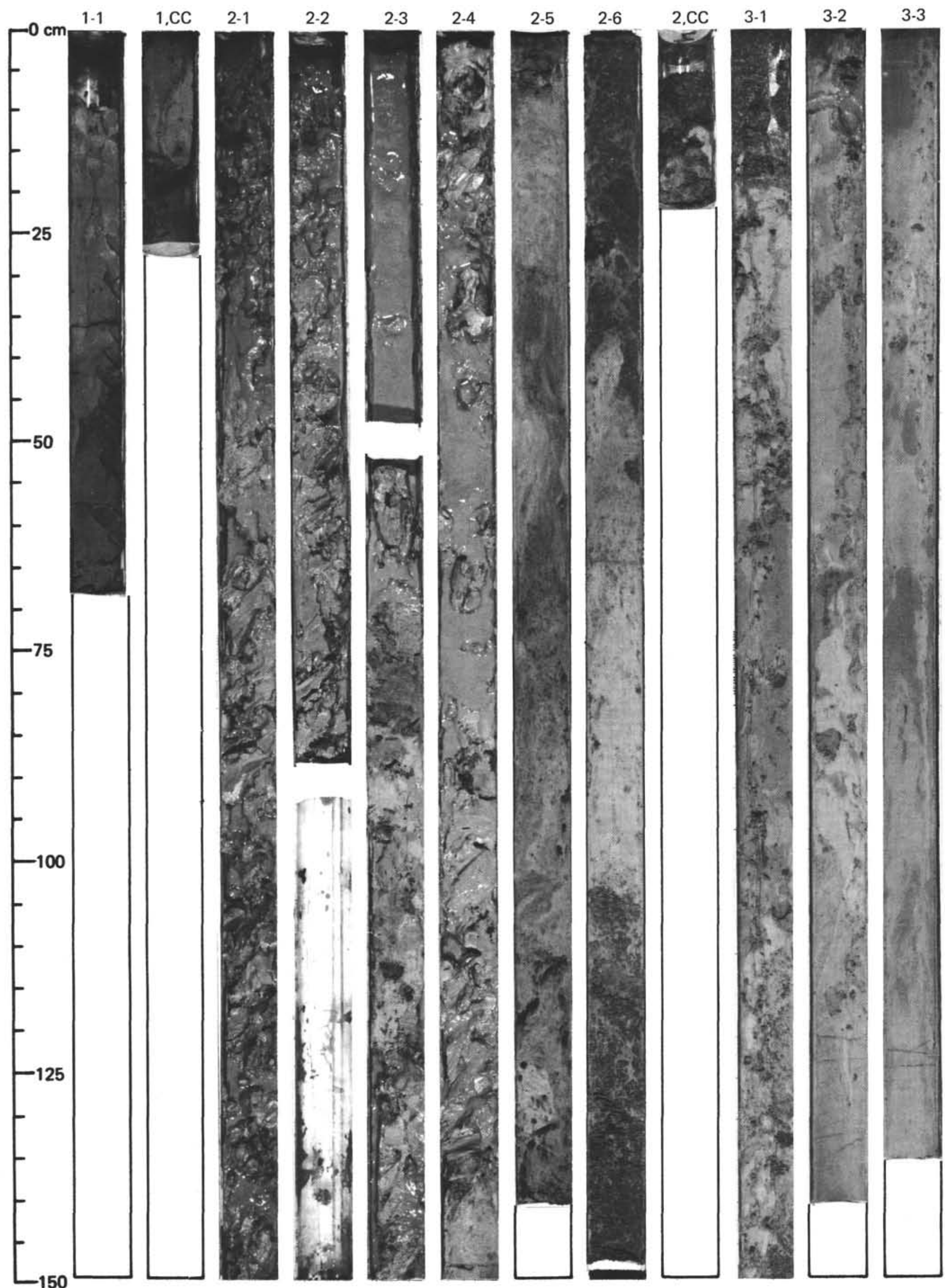


SITE 541

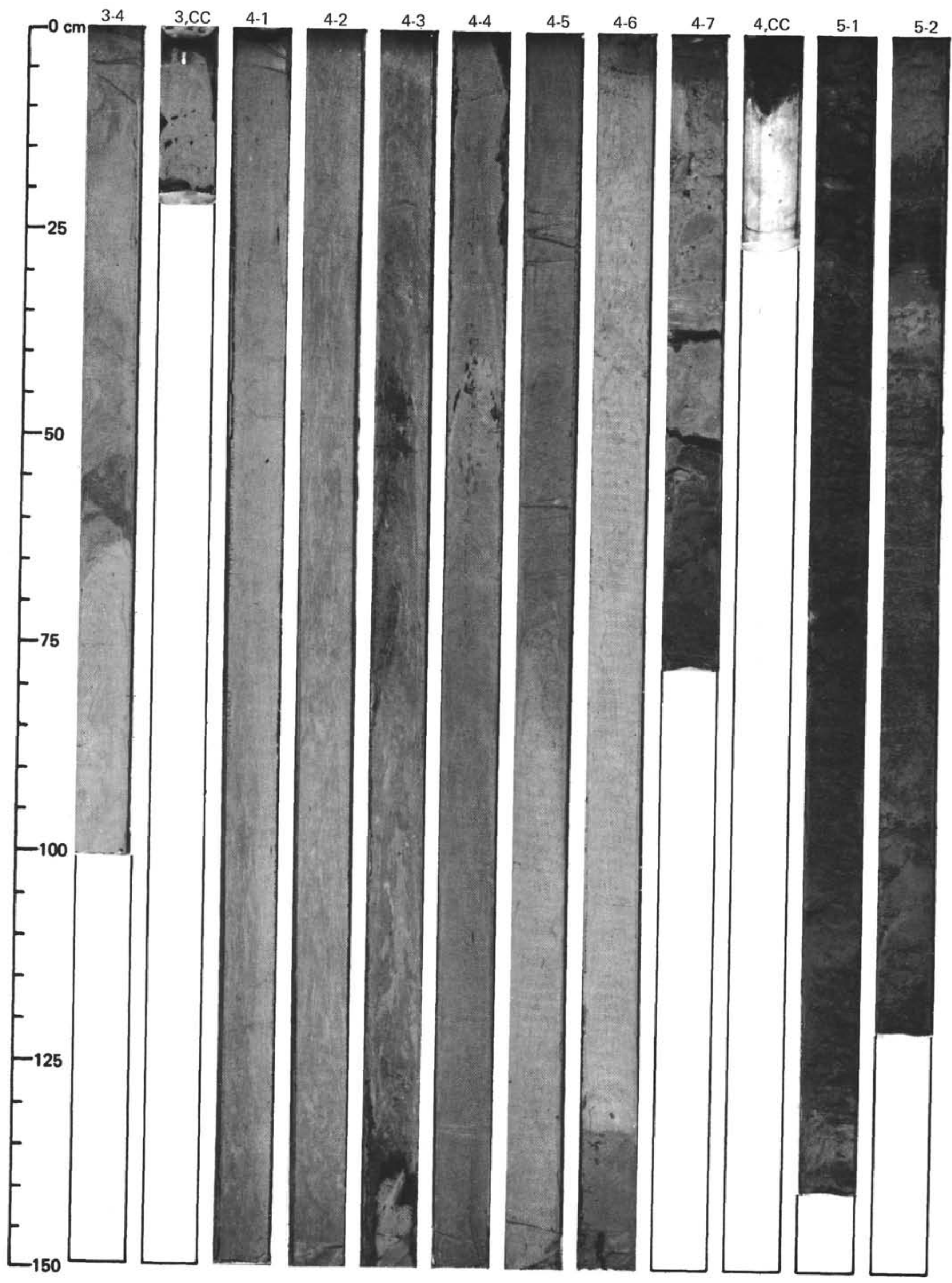




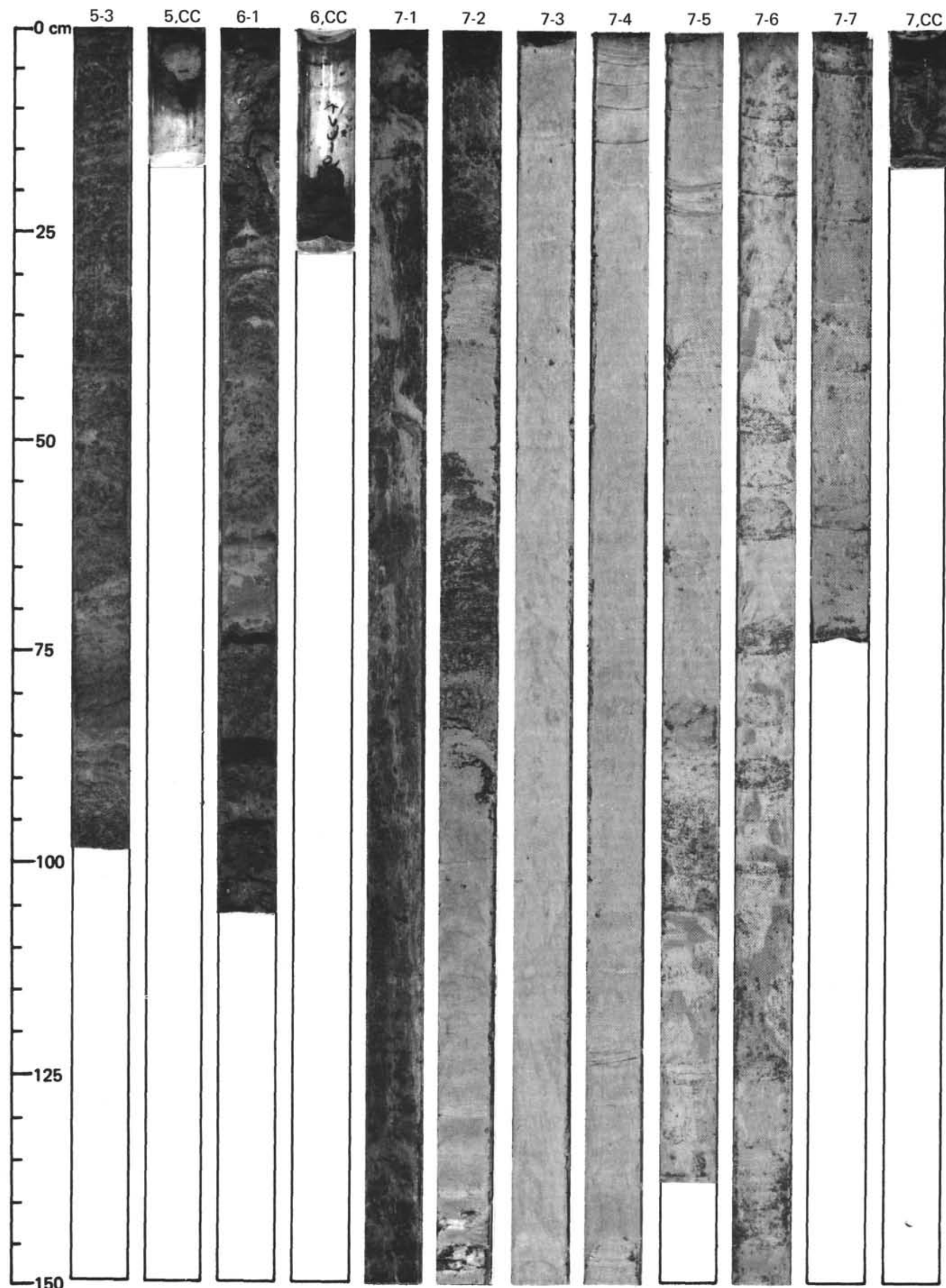




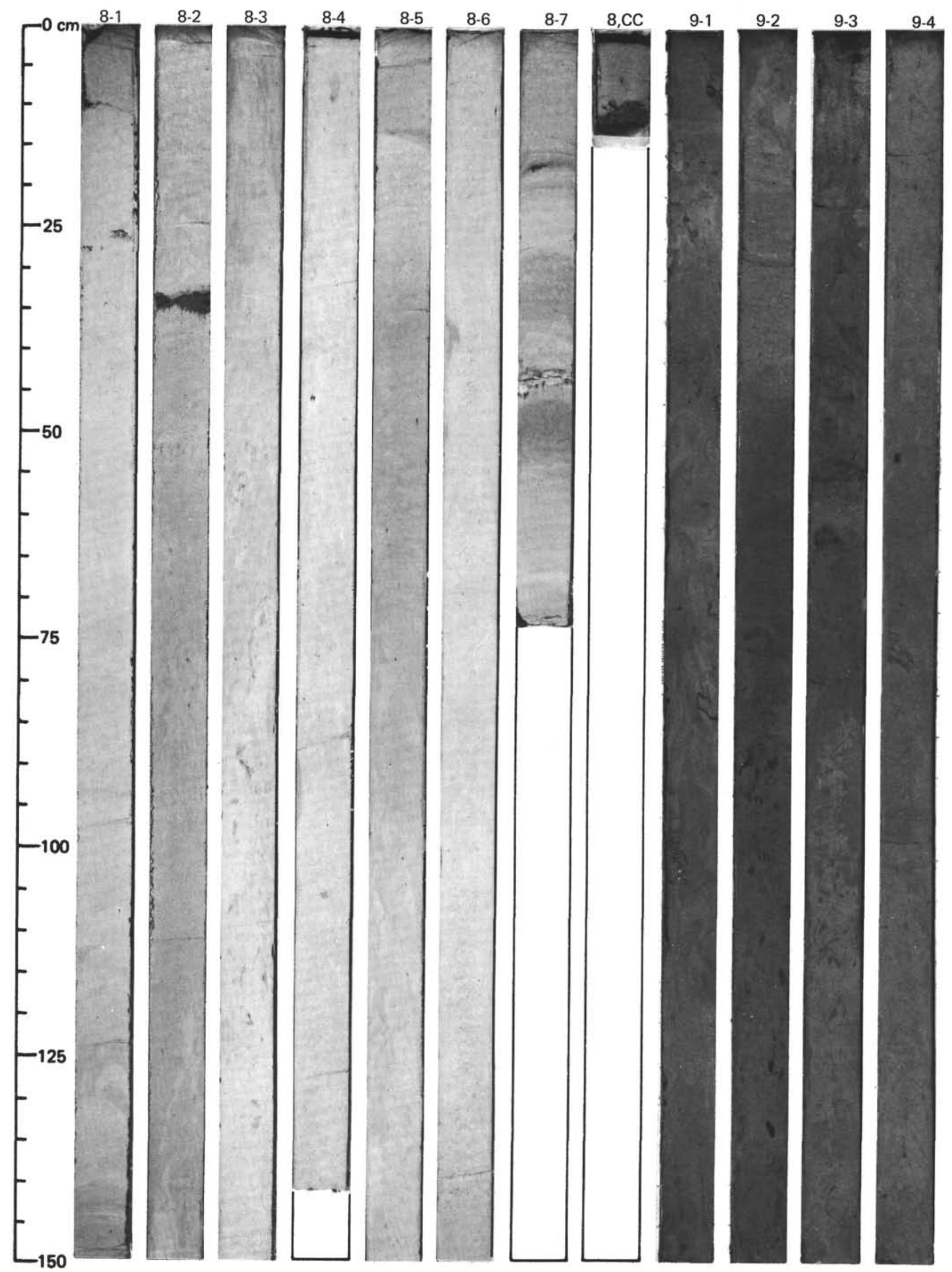




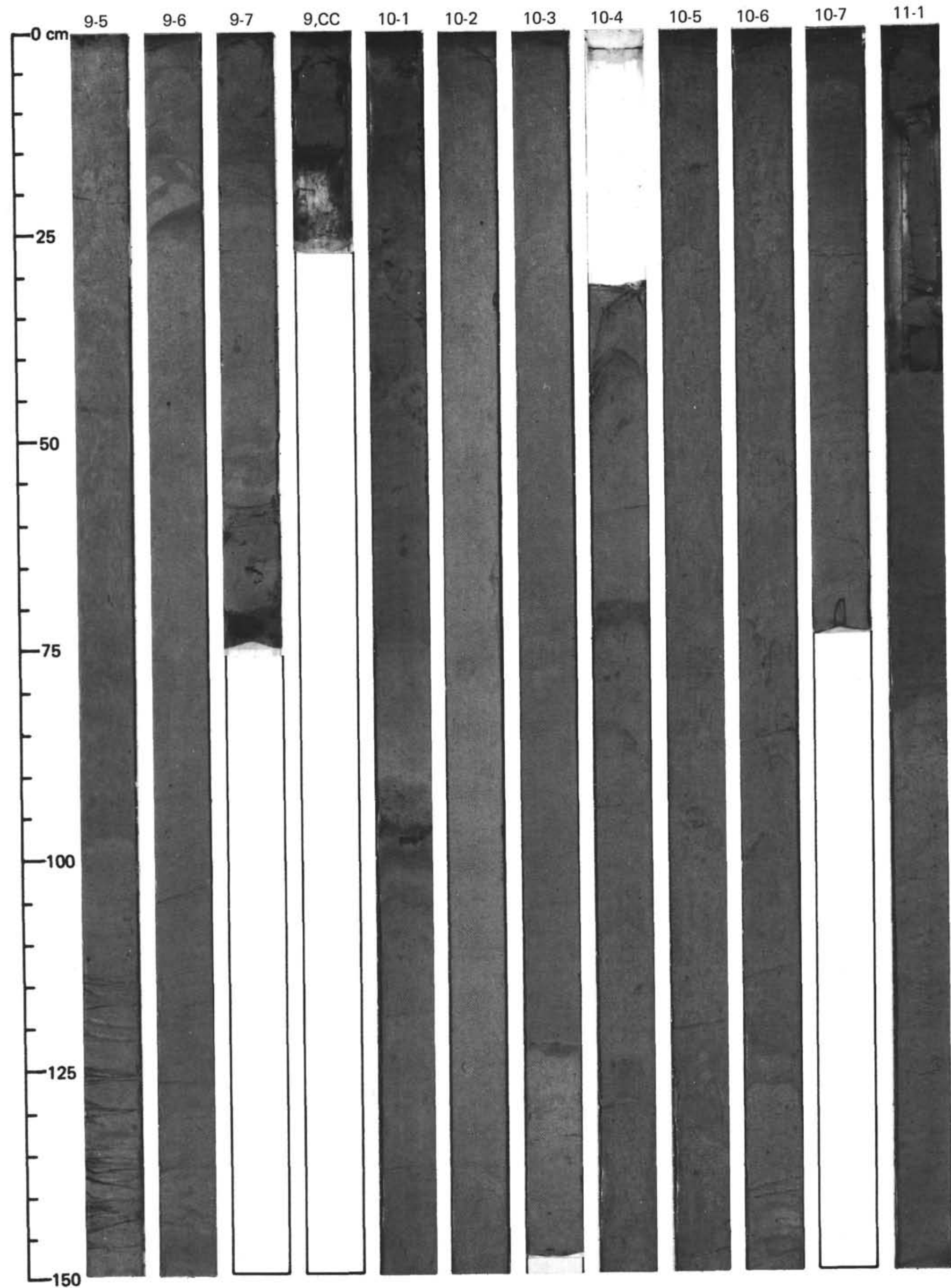




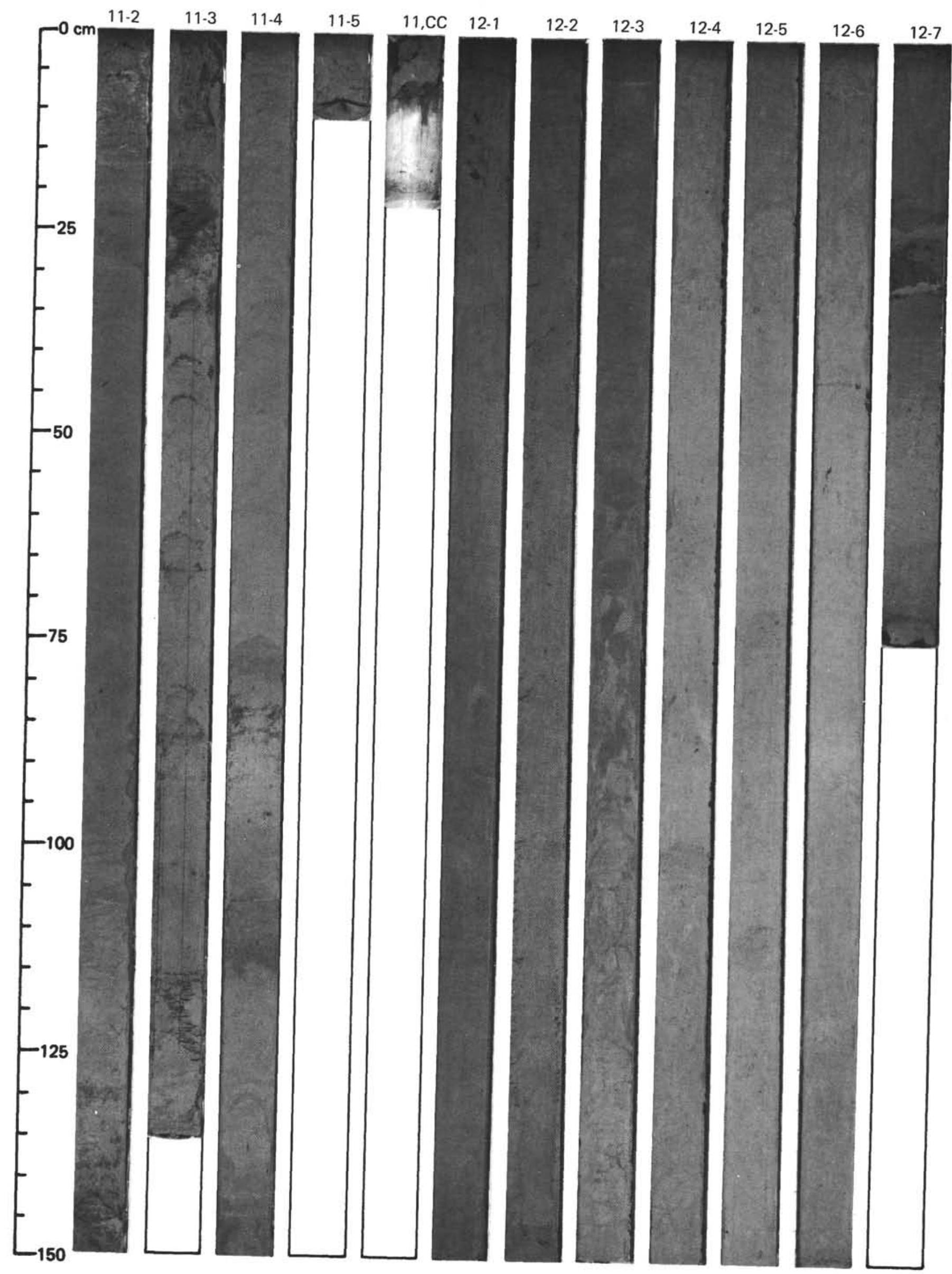


SITE 541

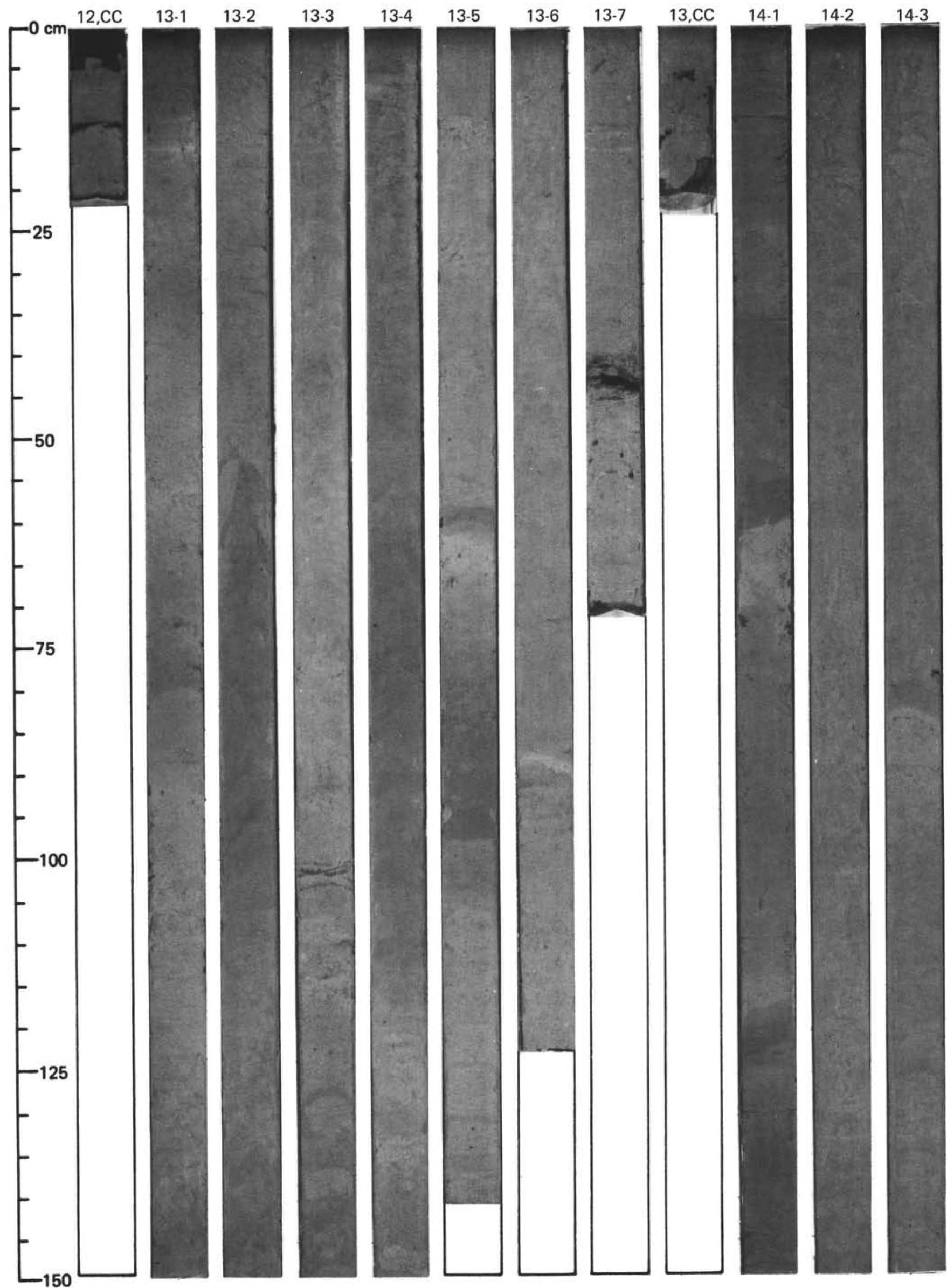


SITE 541

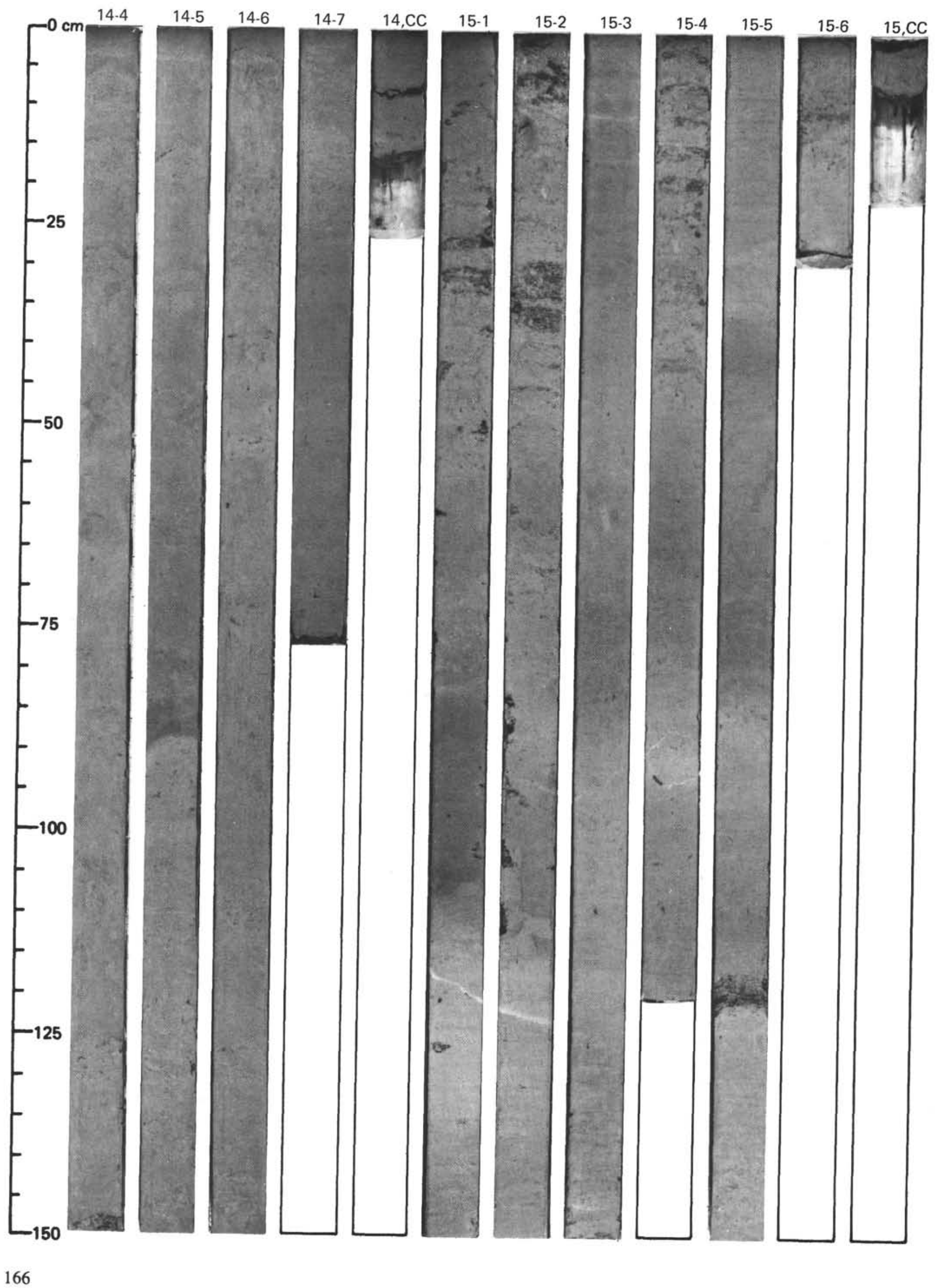




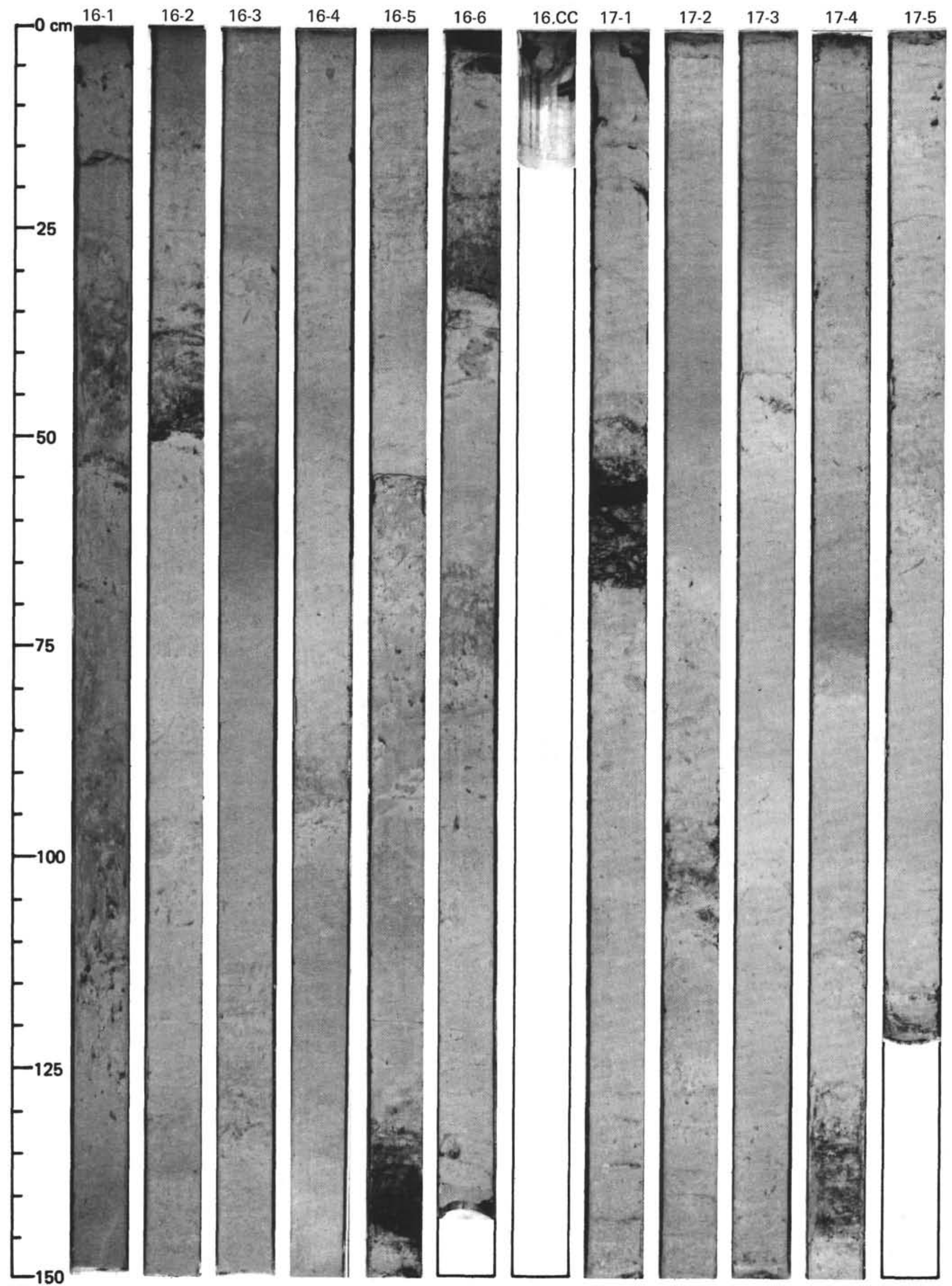




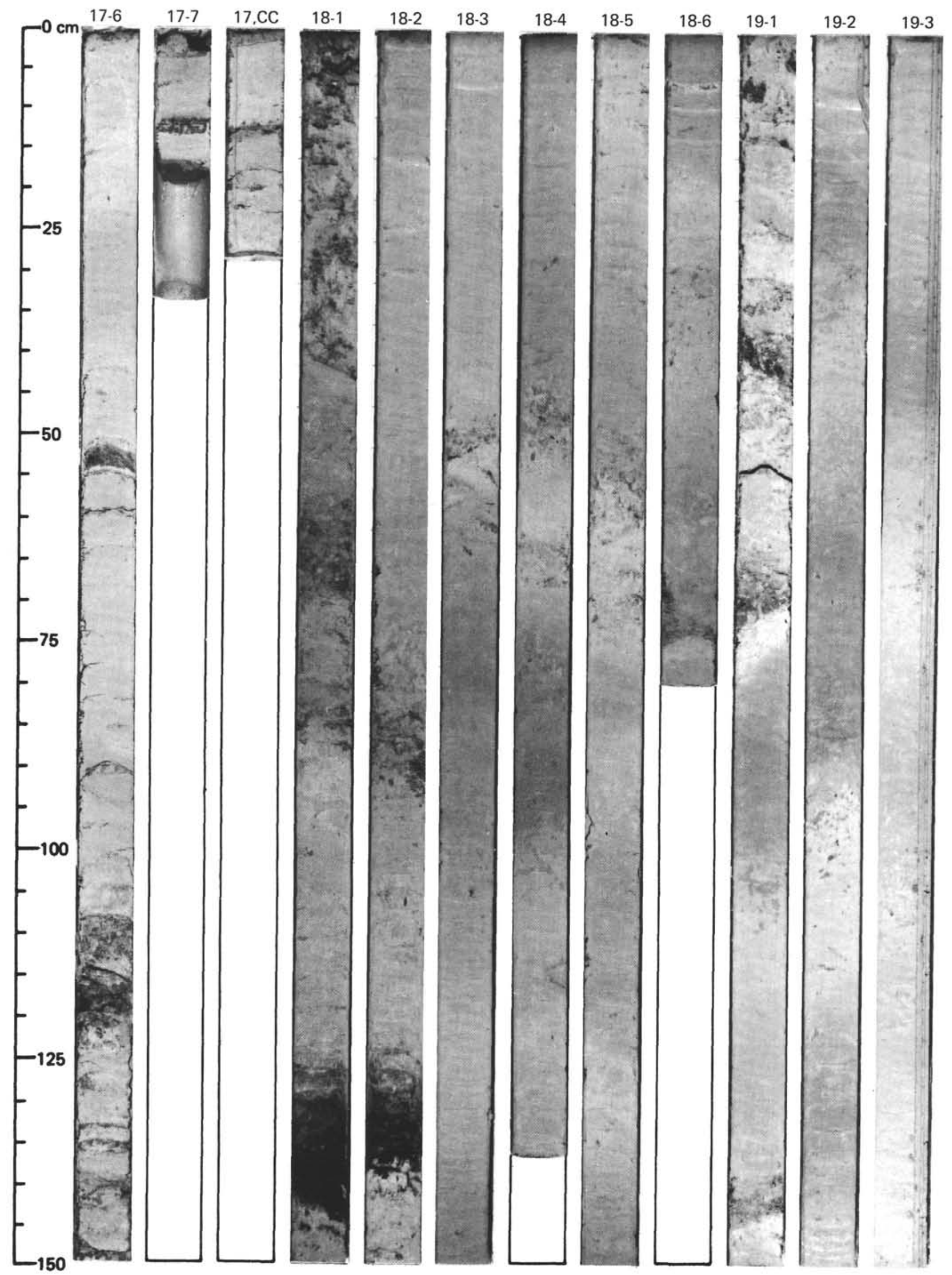




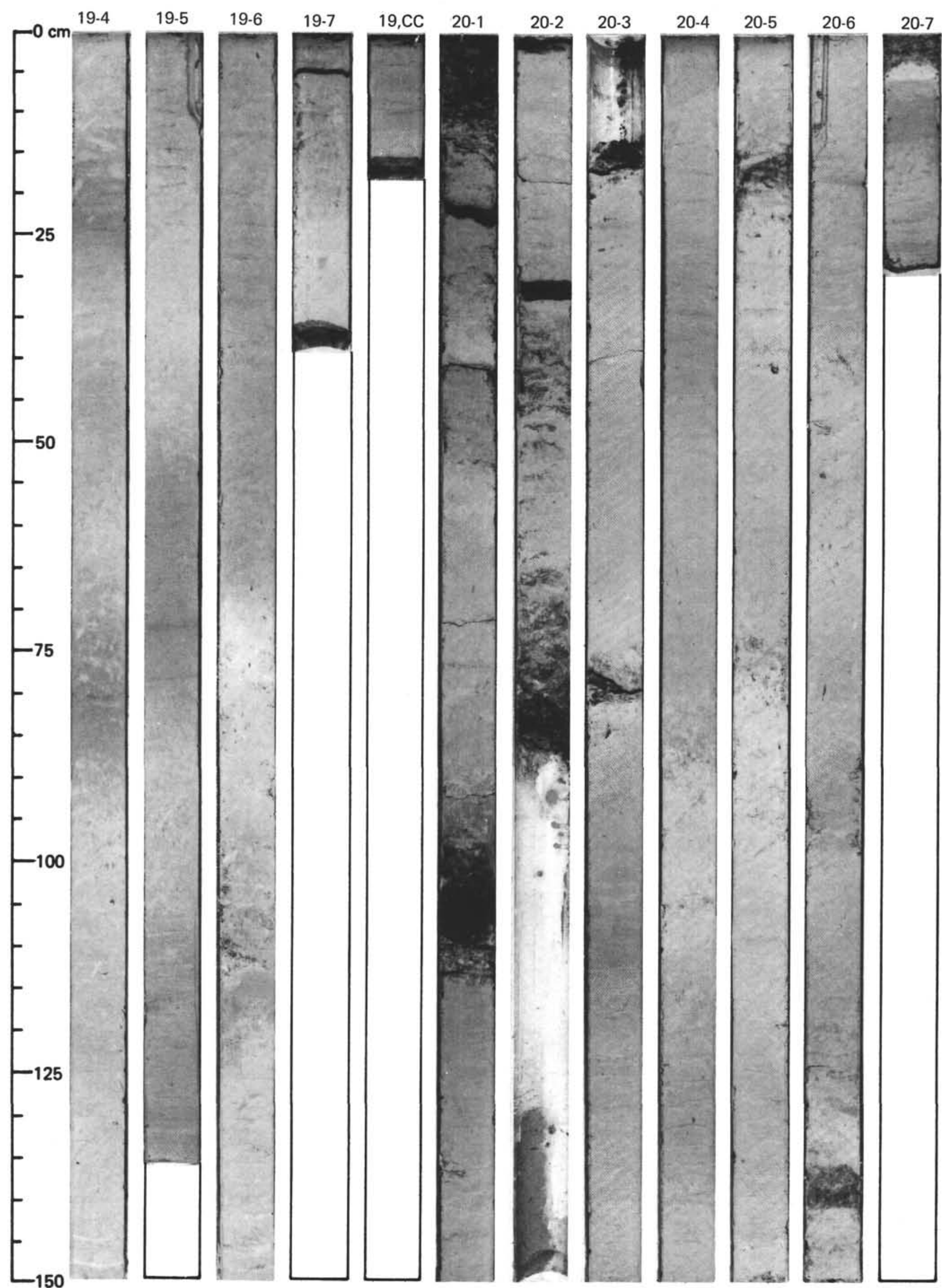




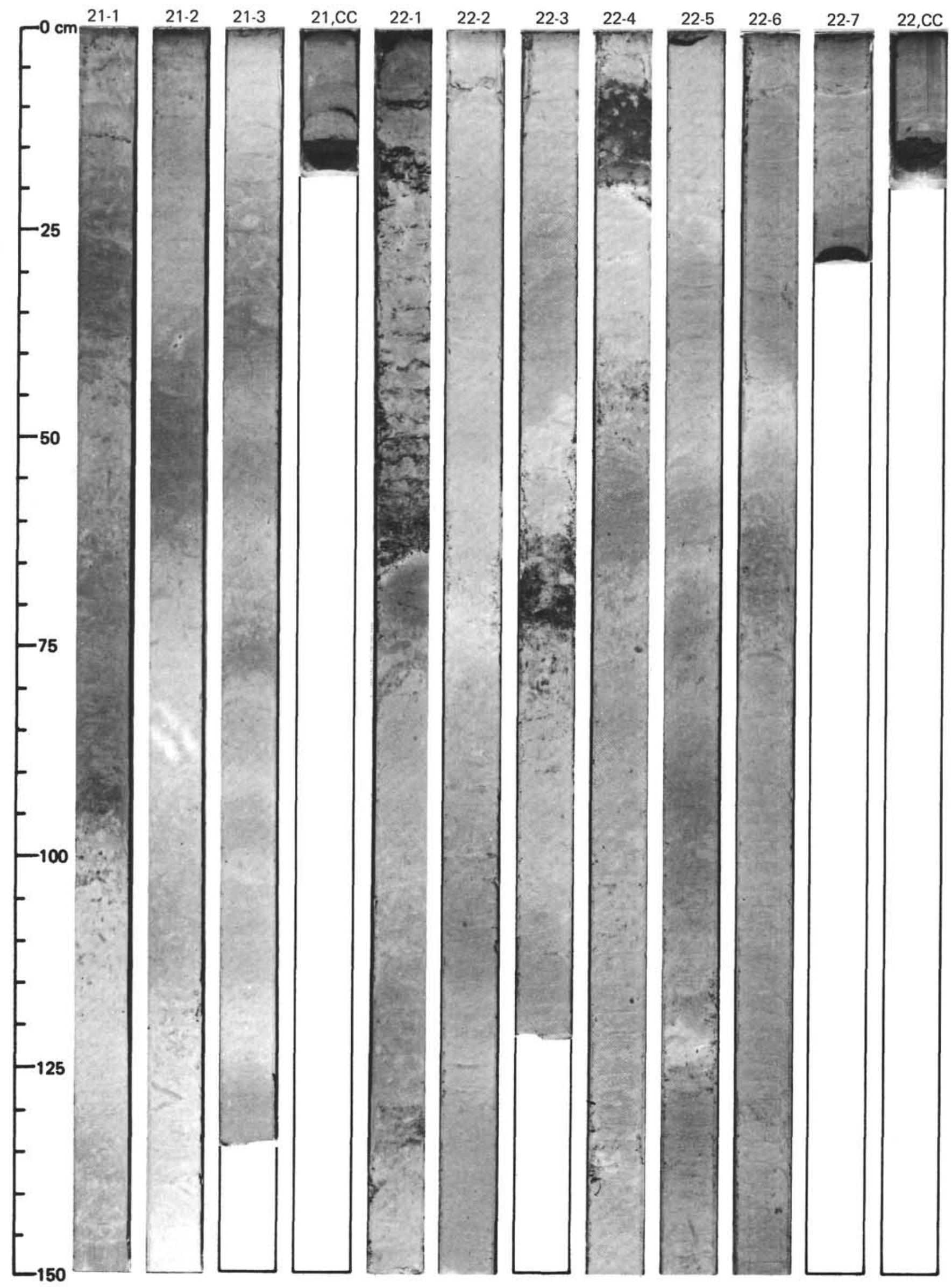




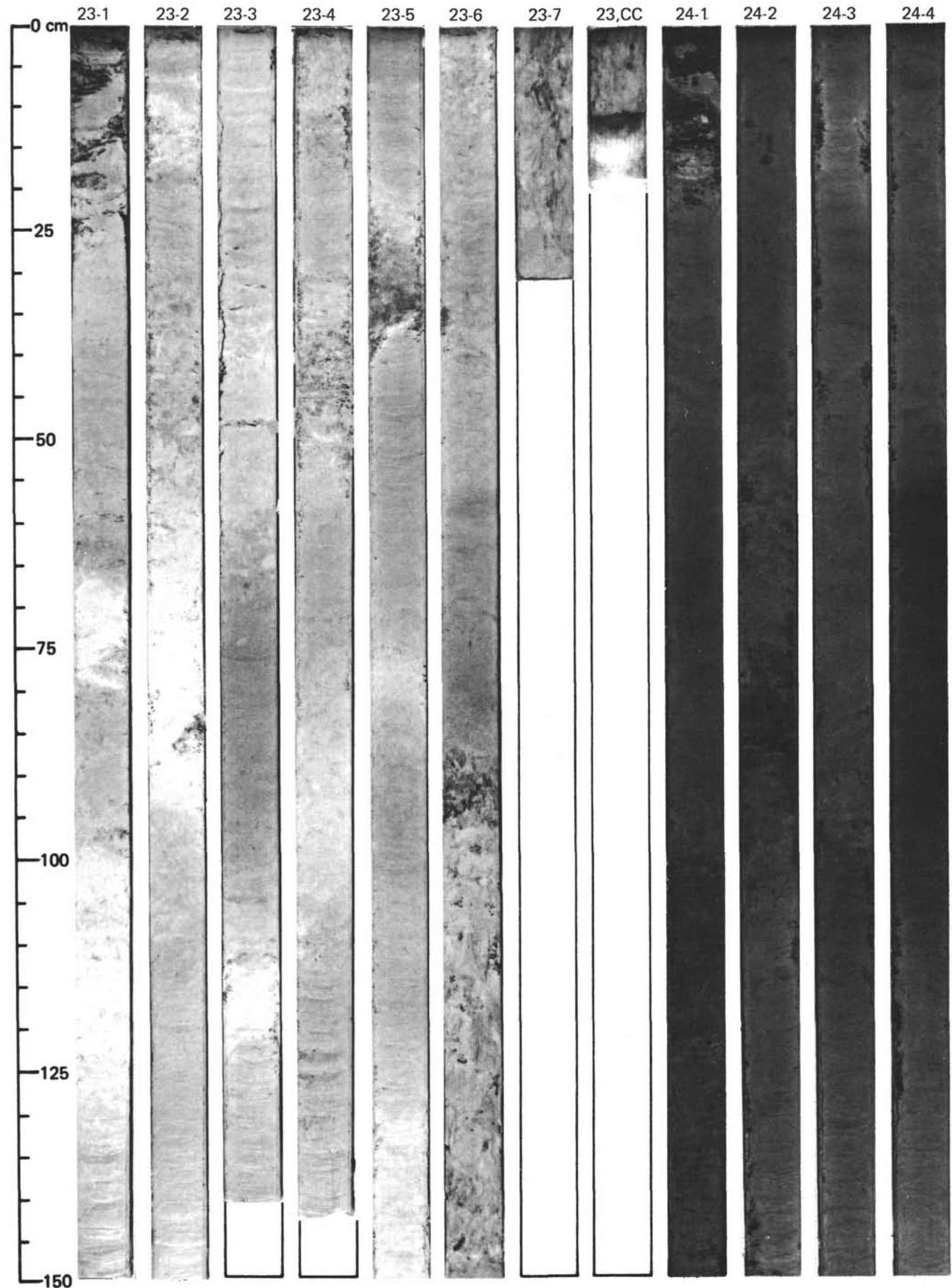




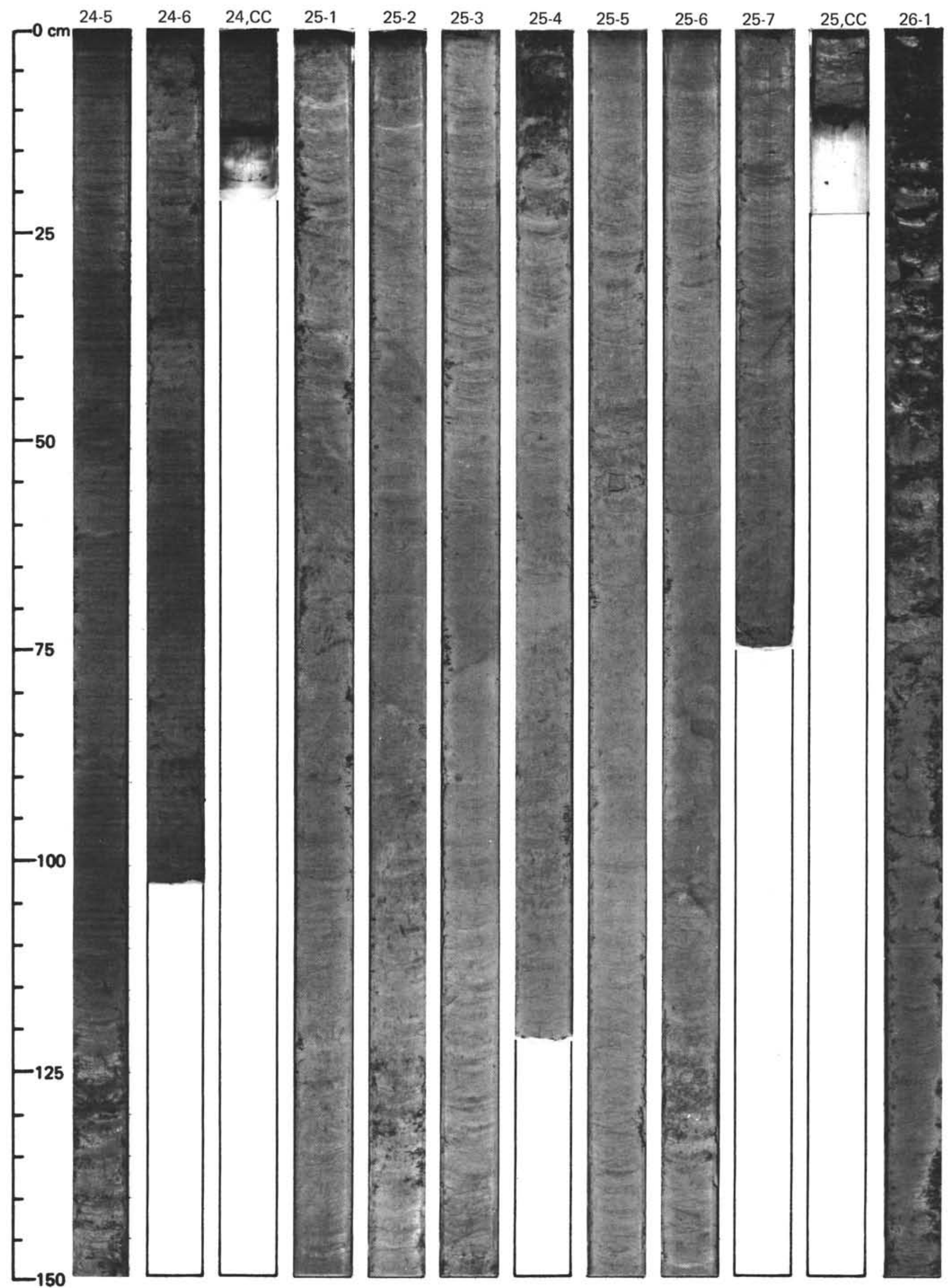


SITE 541

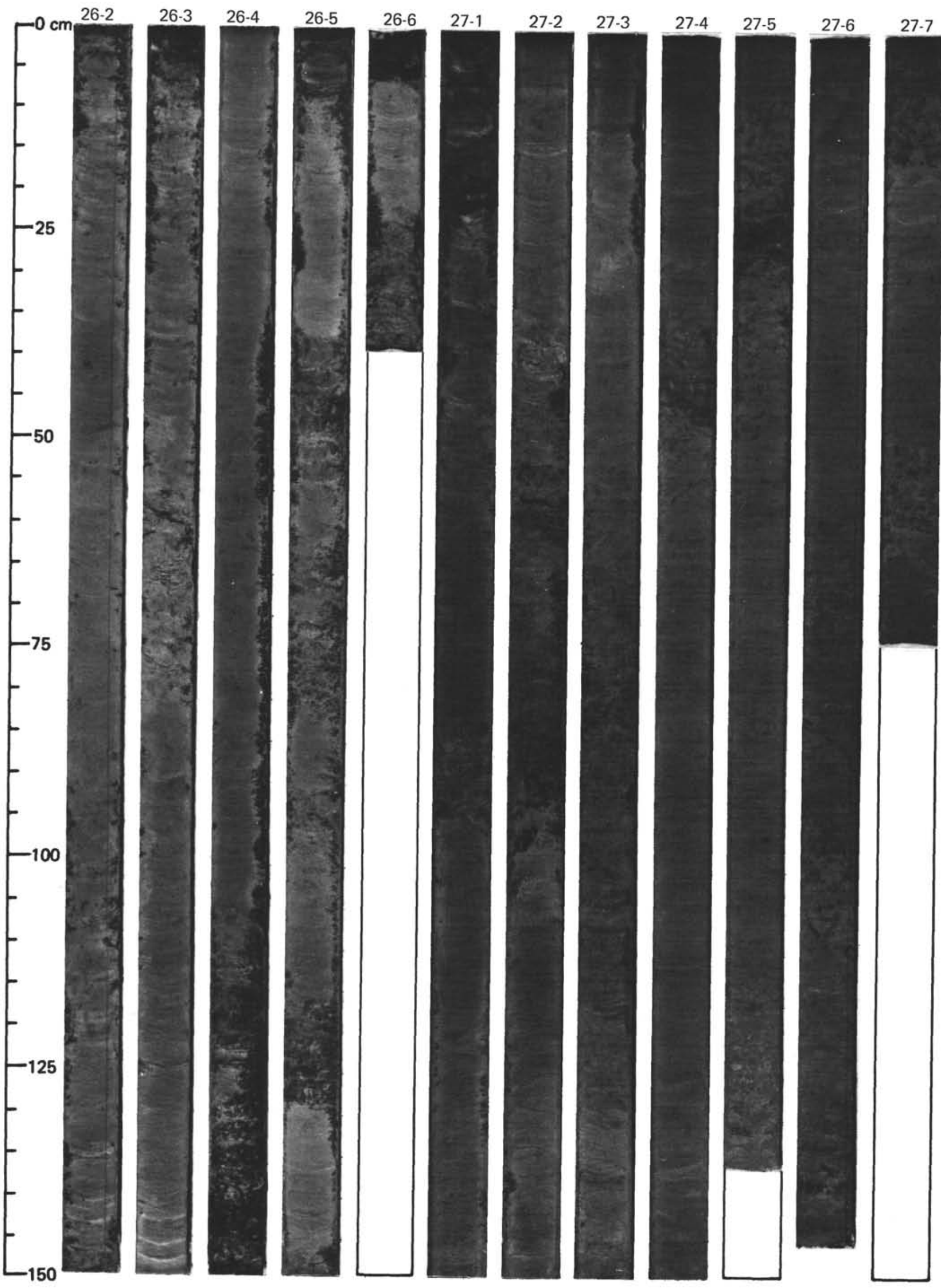




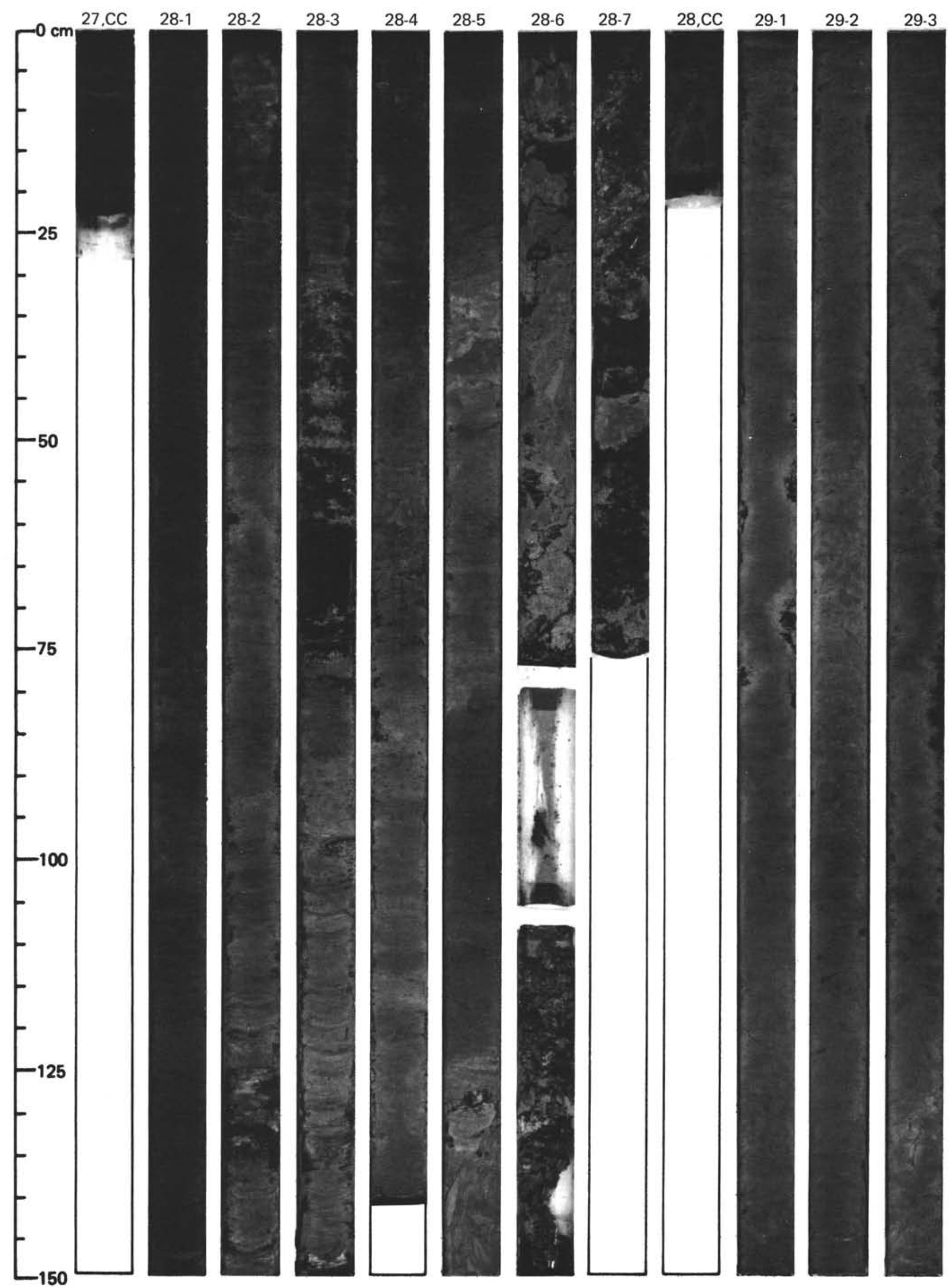


SITE 541

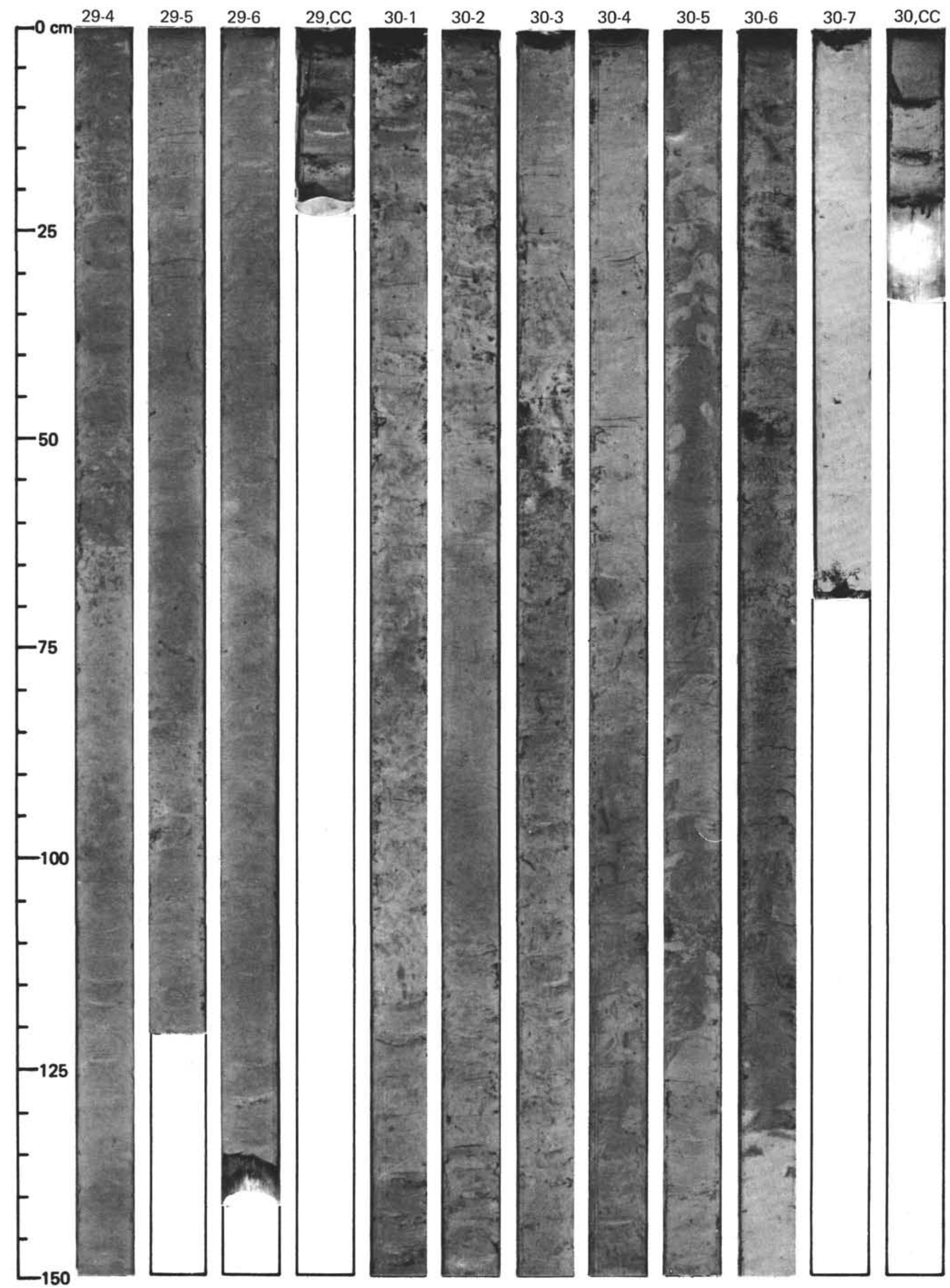




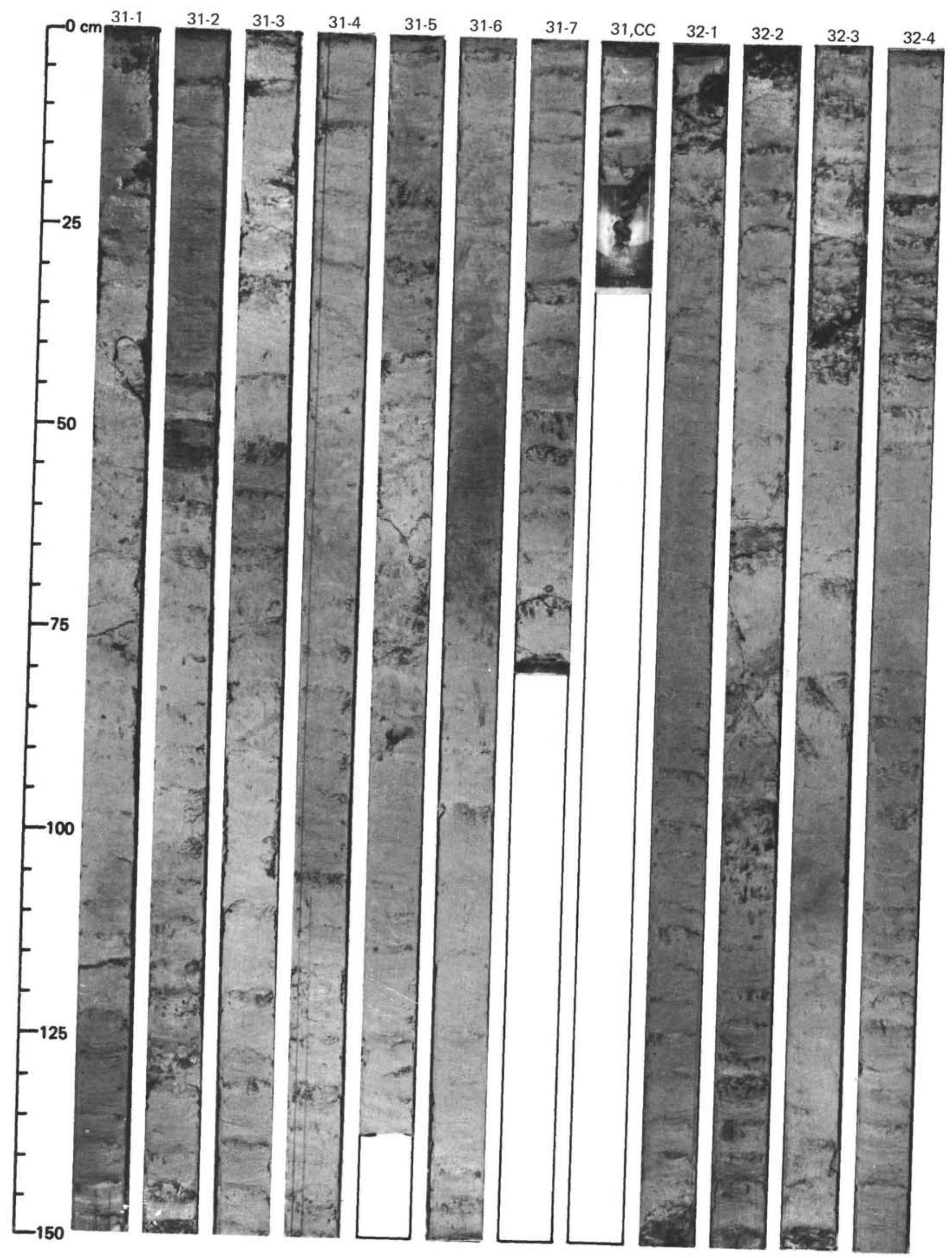




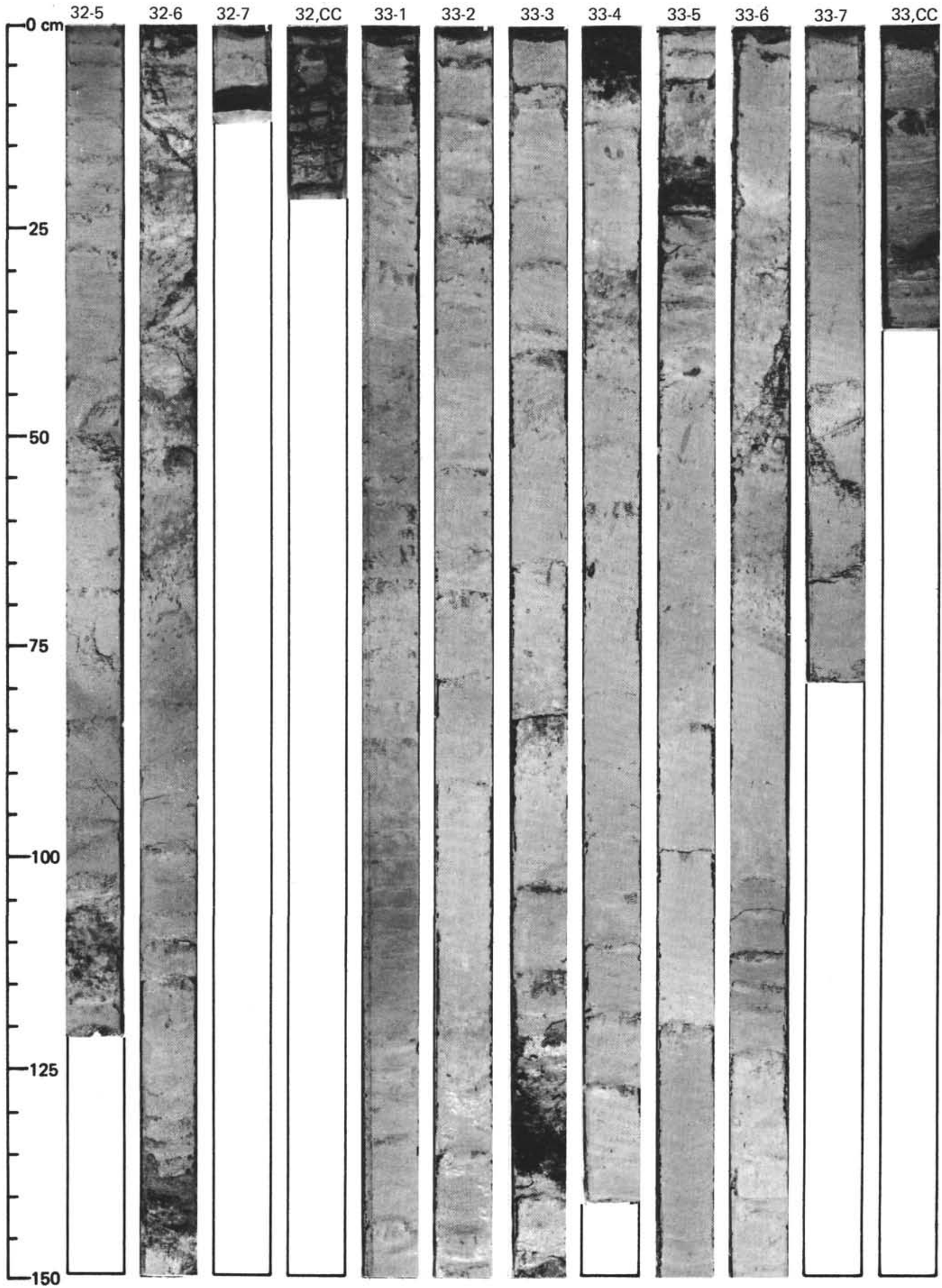




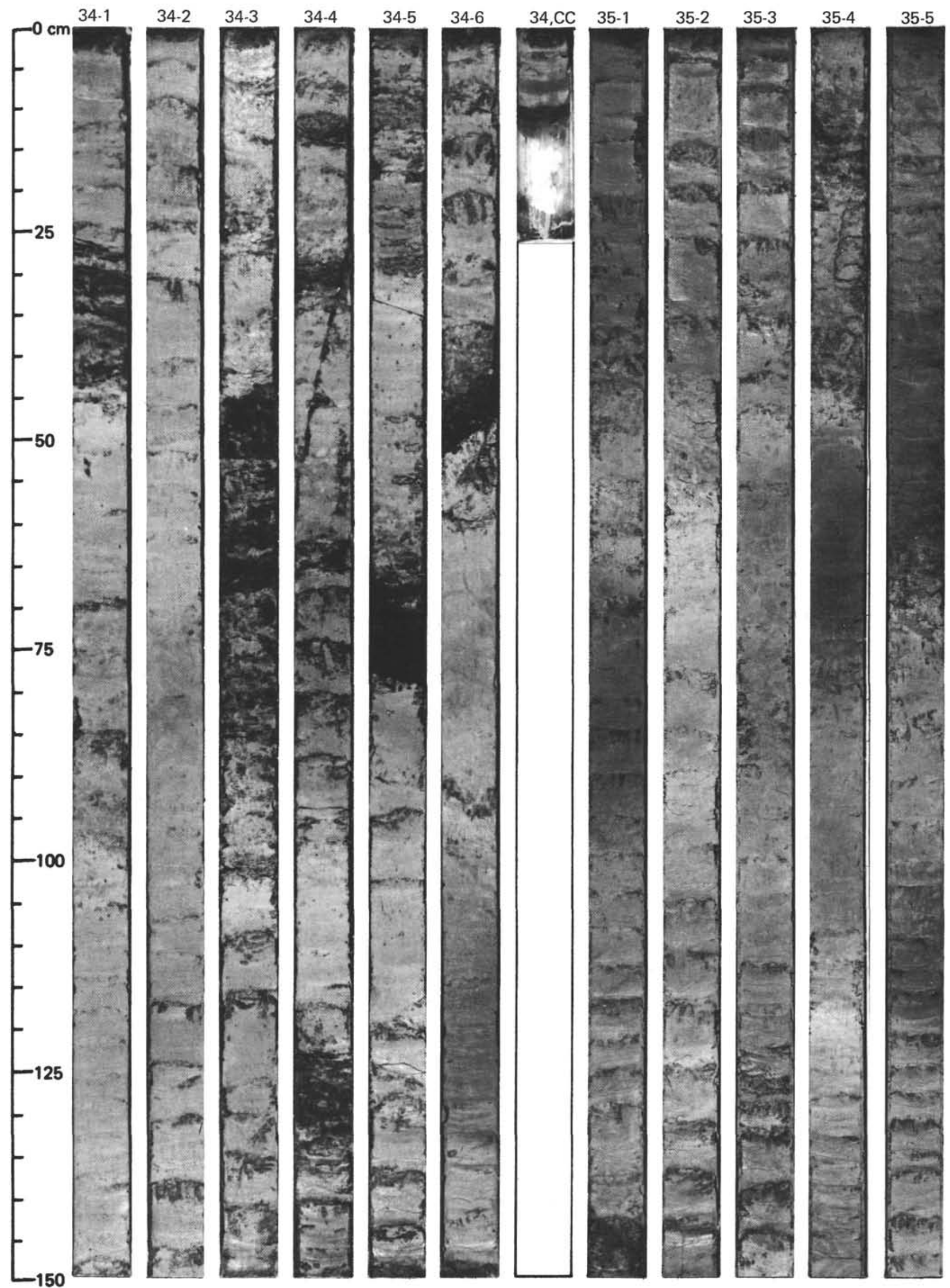




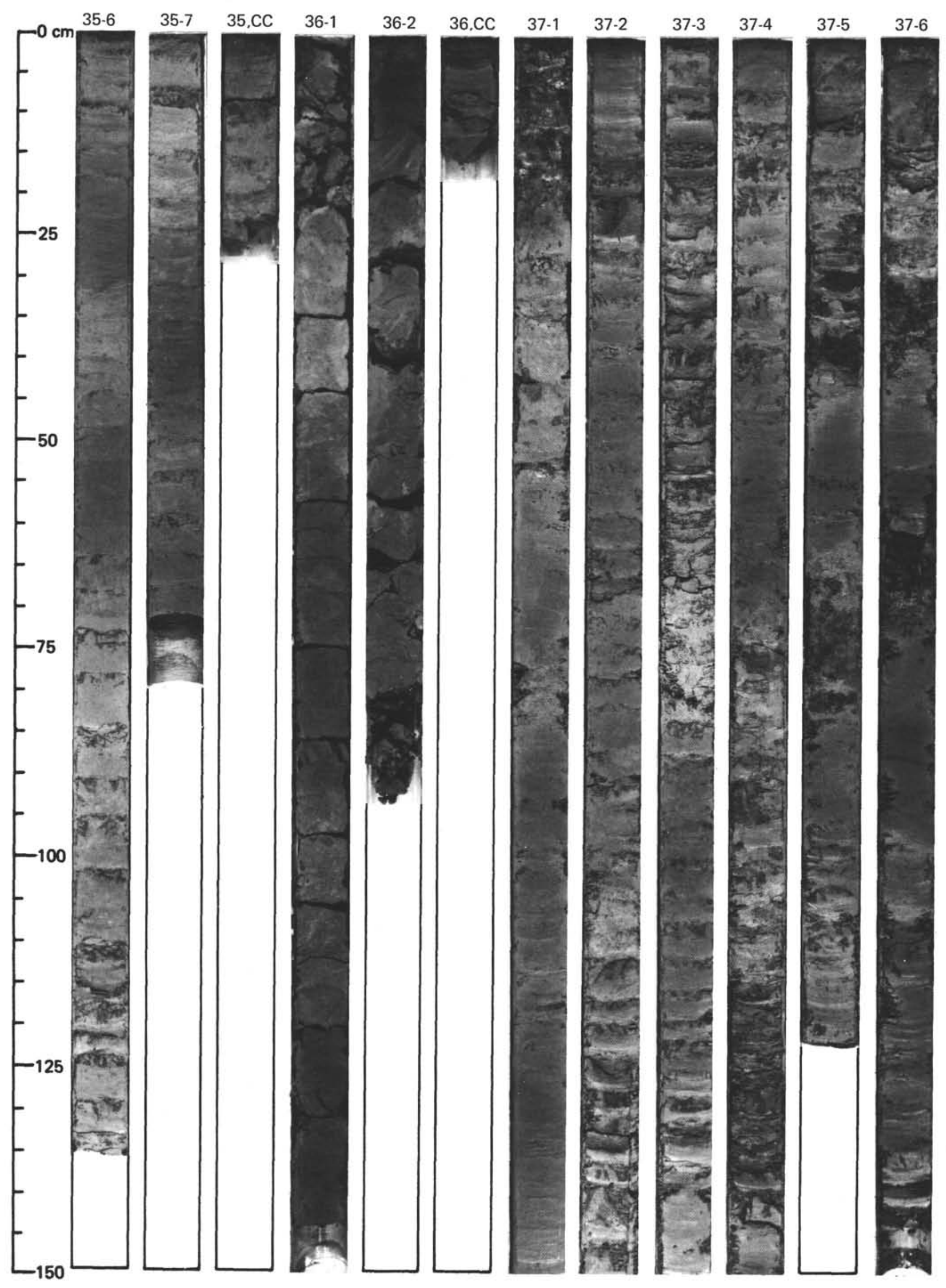




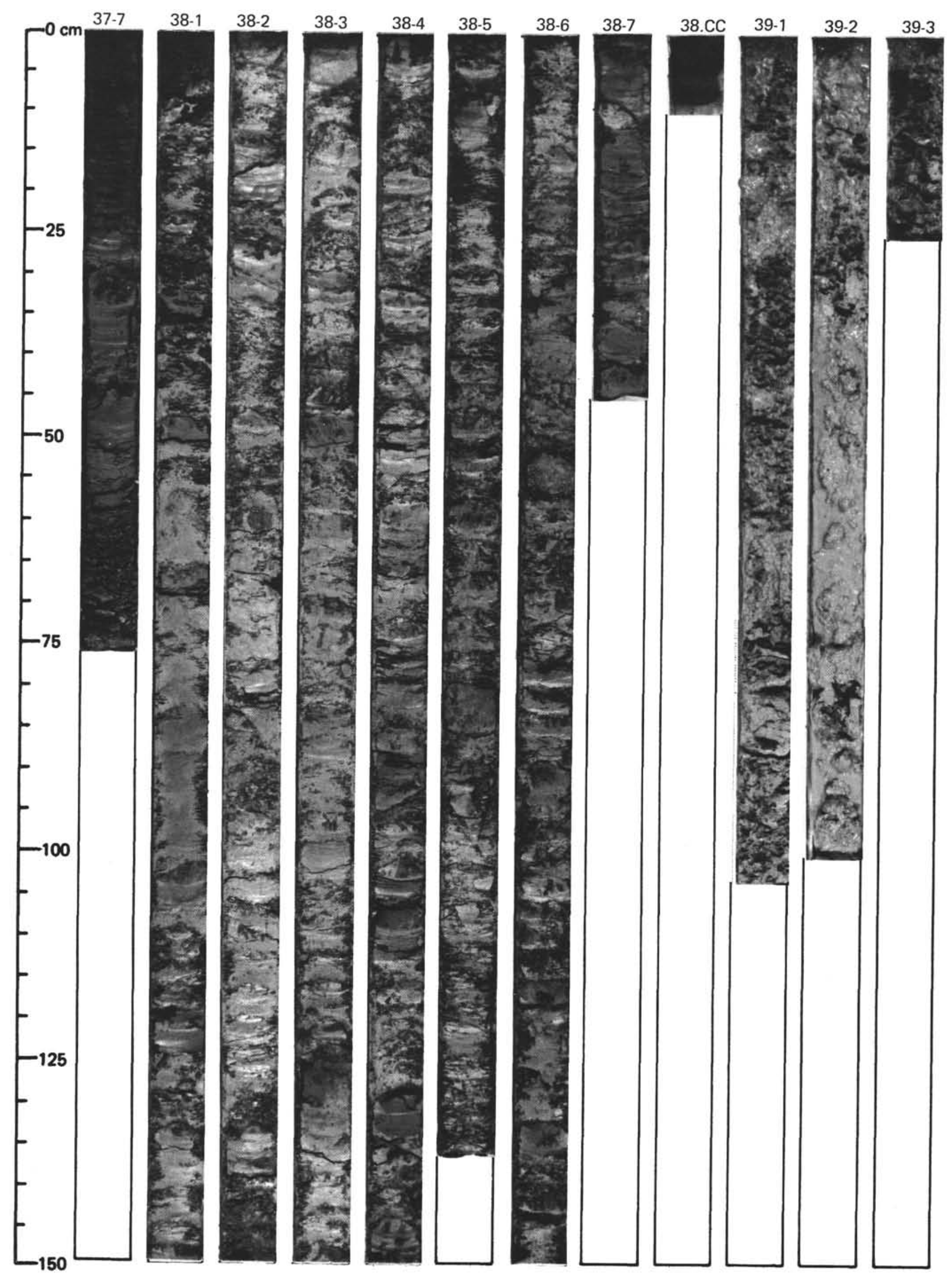




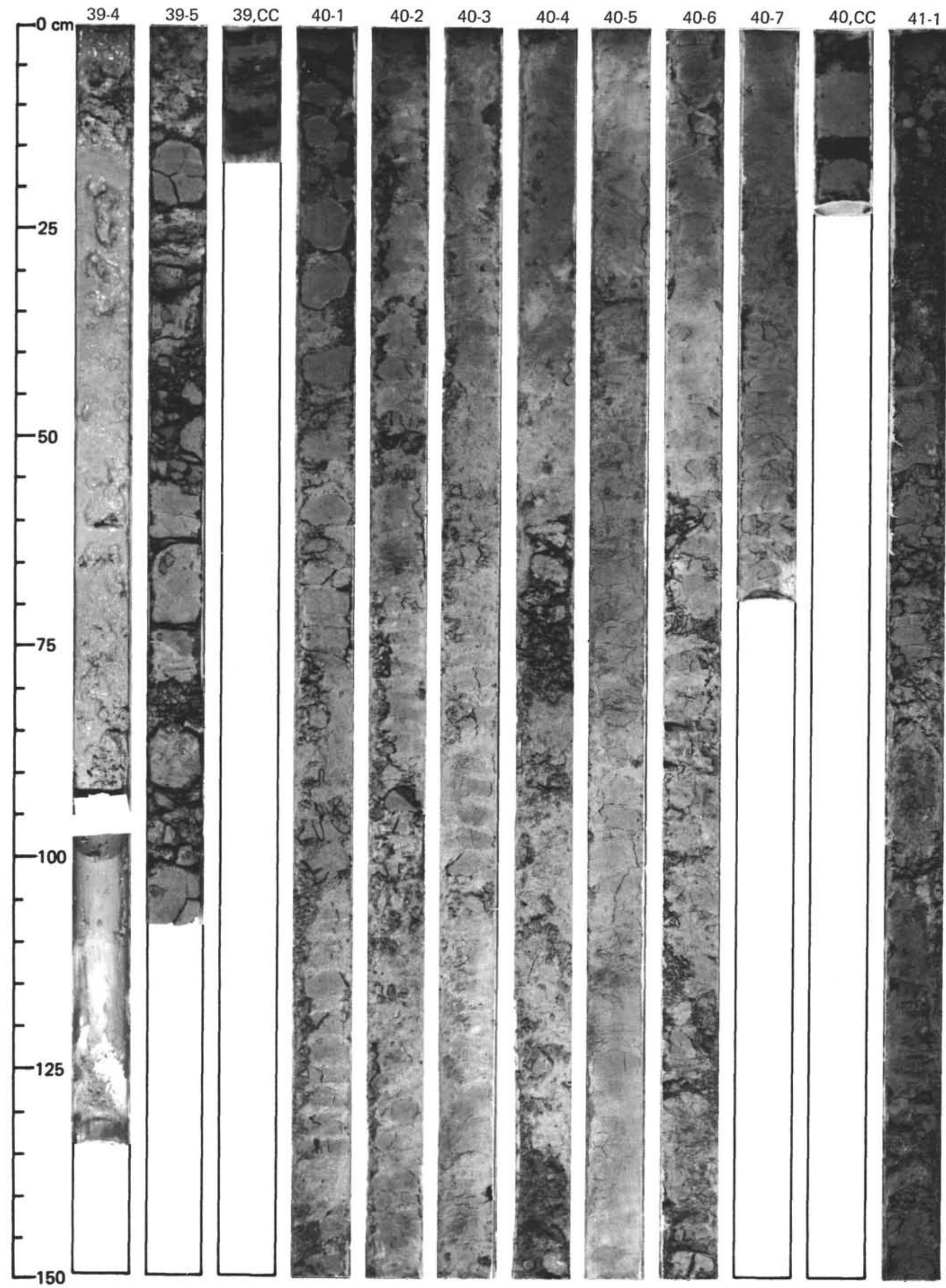




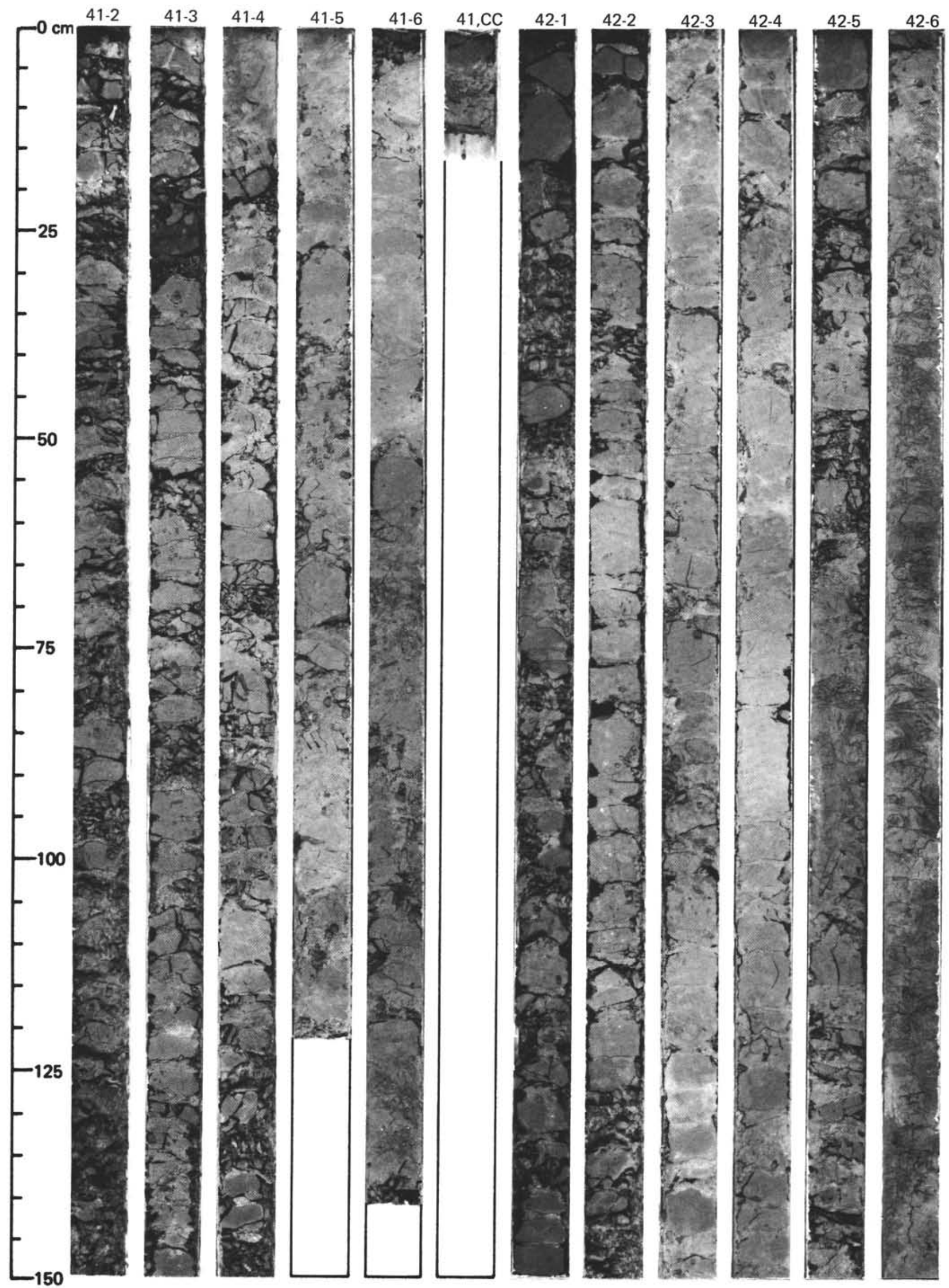


SITE 541

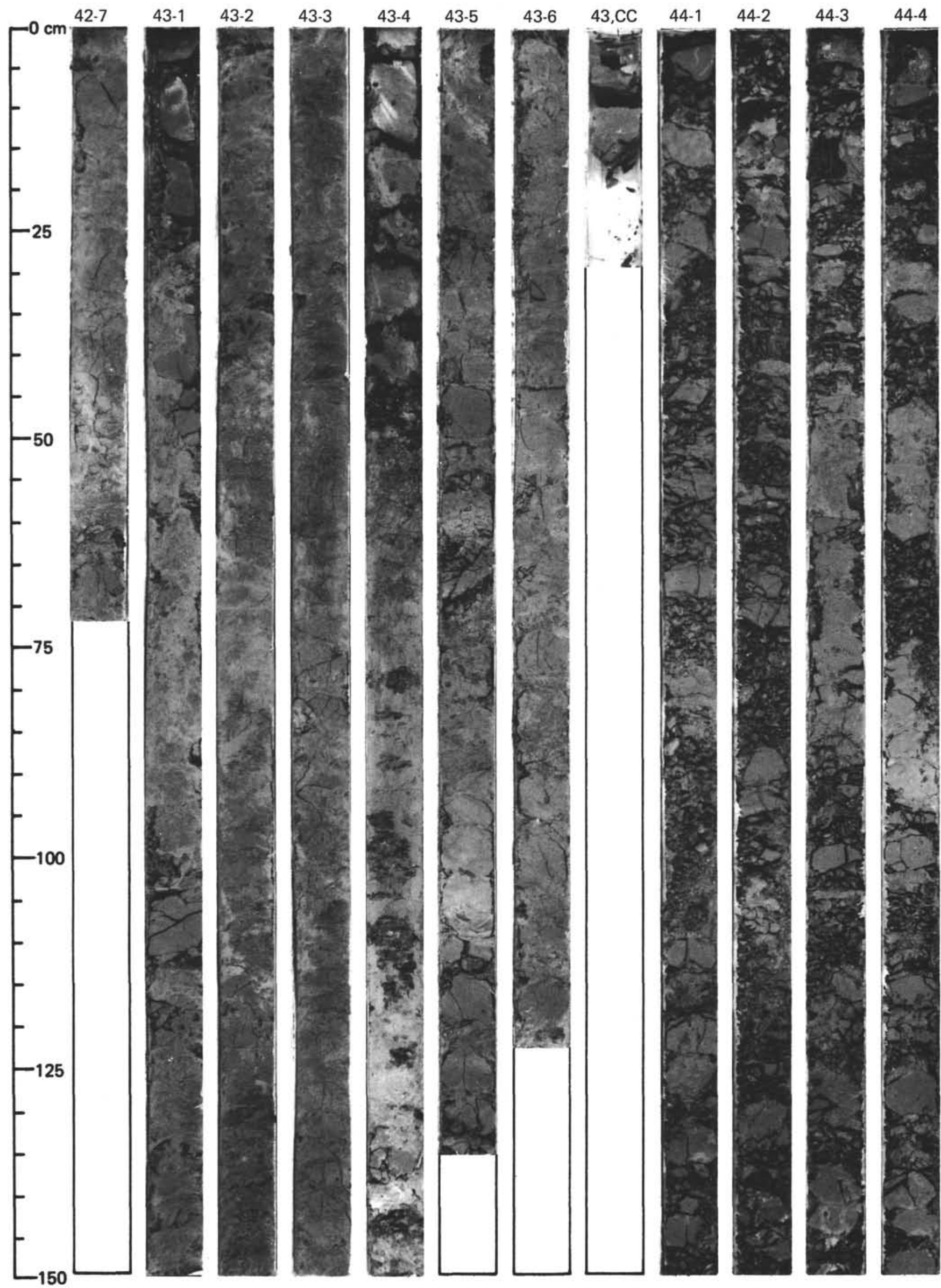




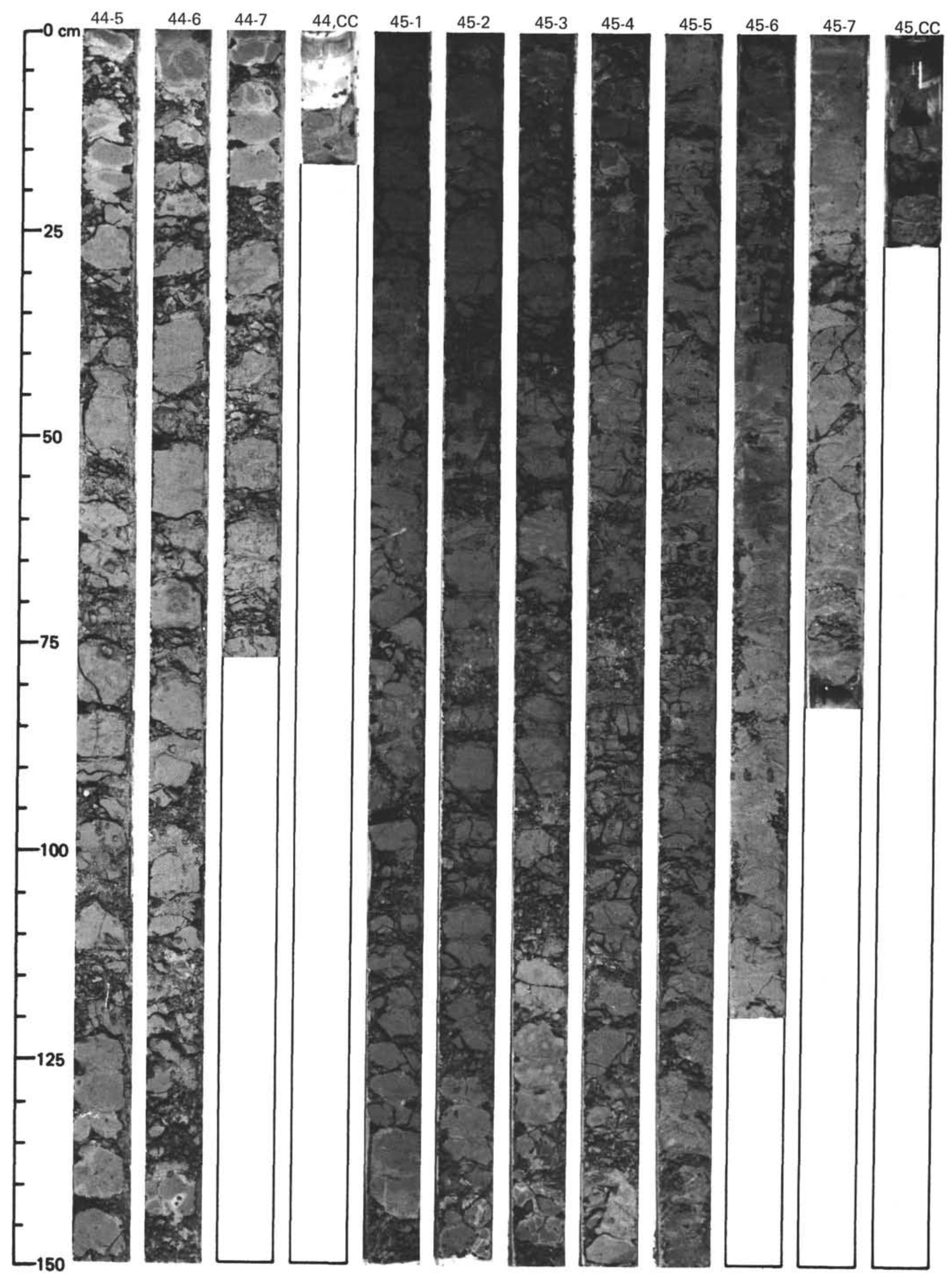




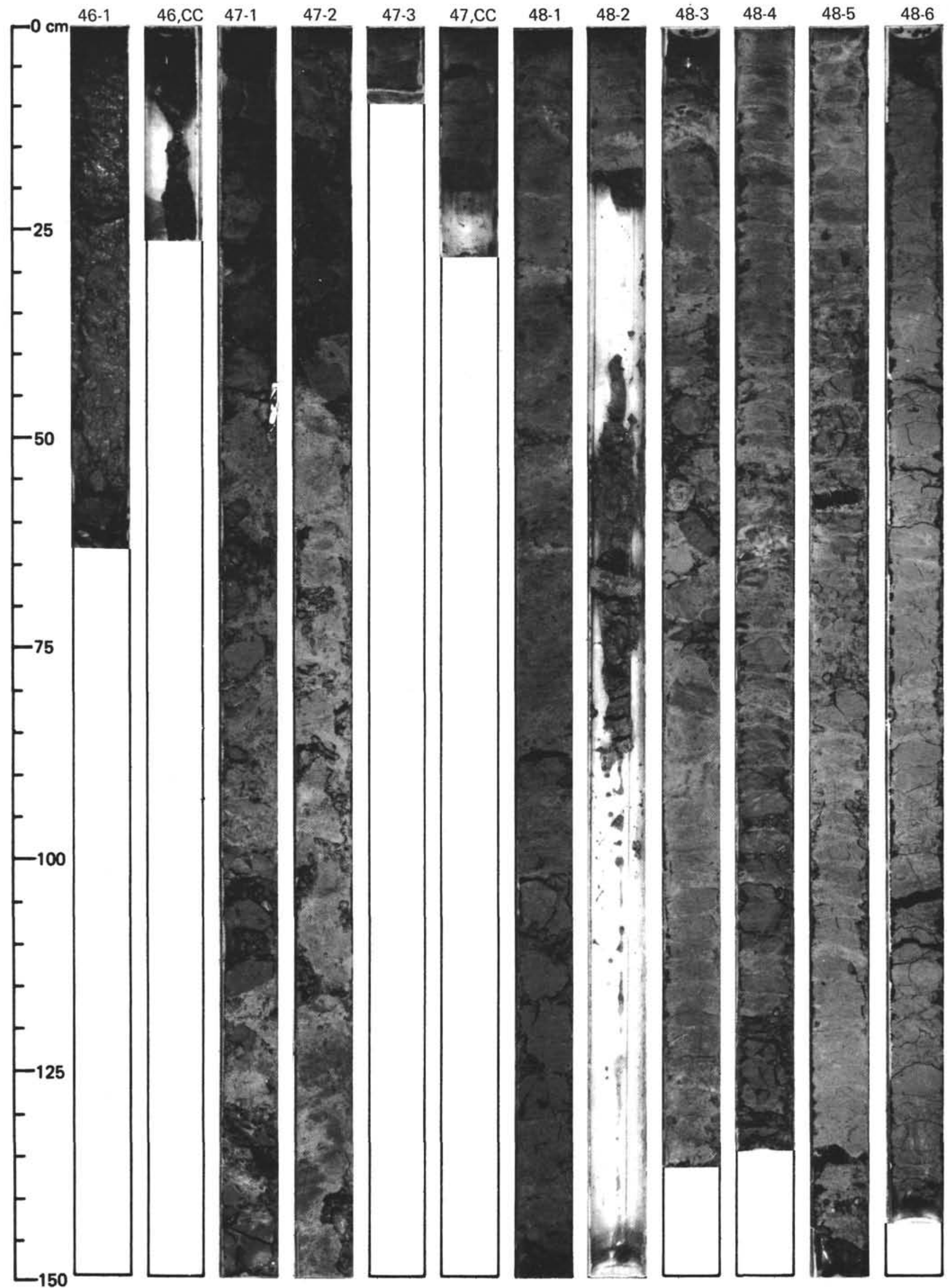




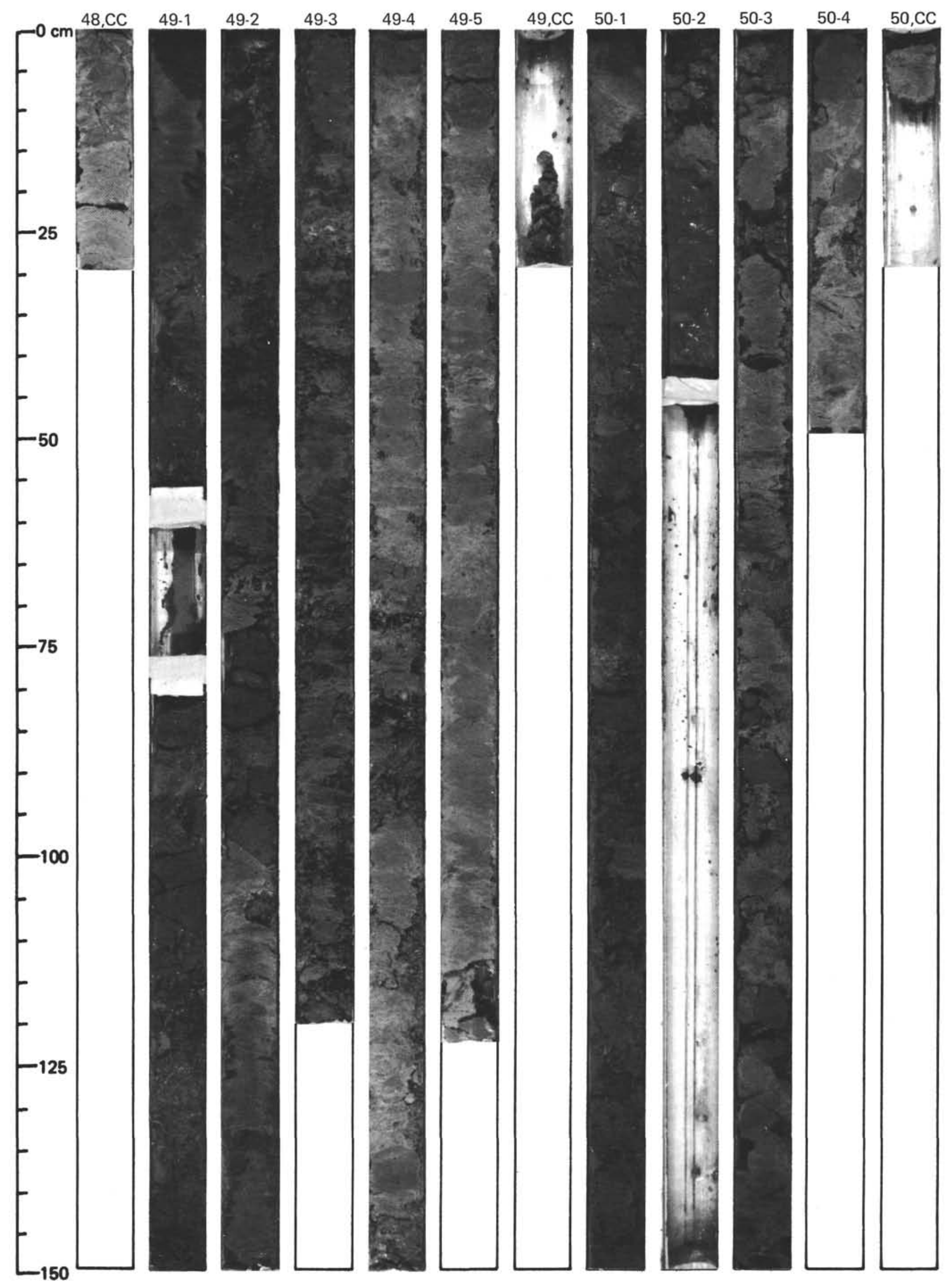

